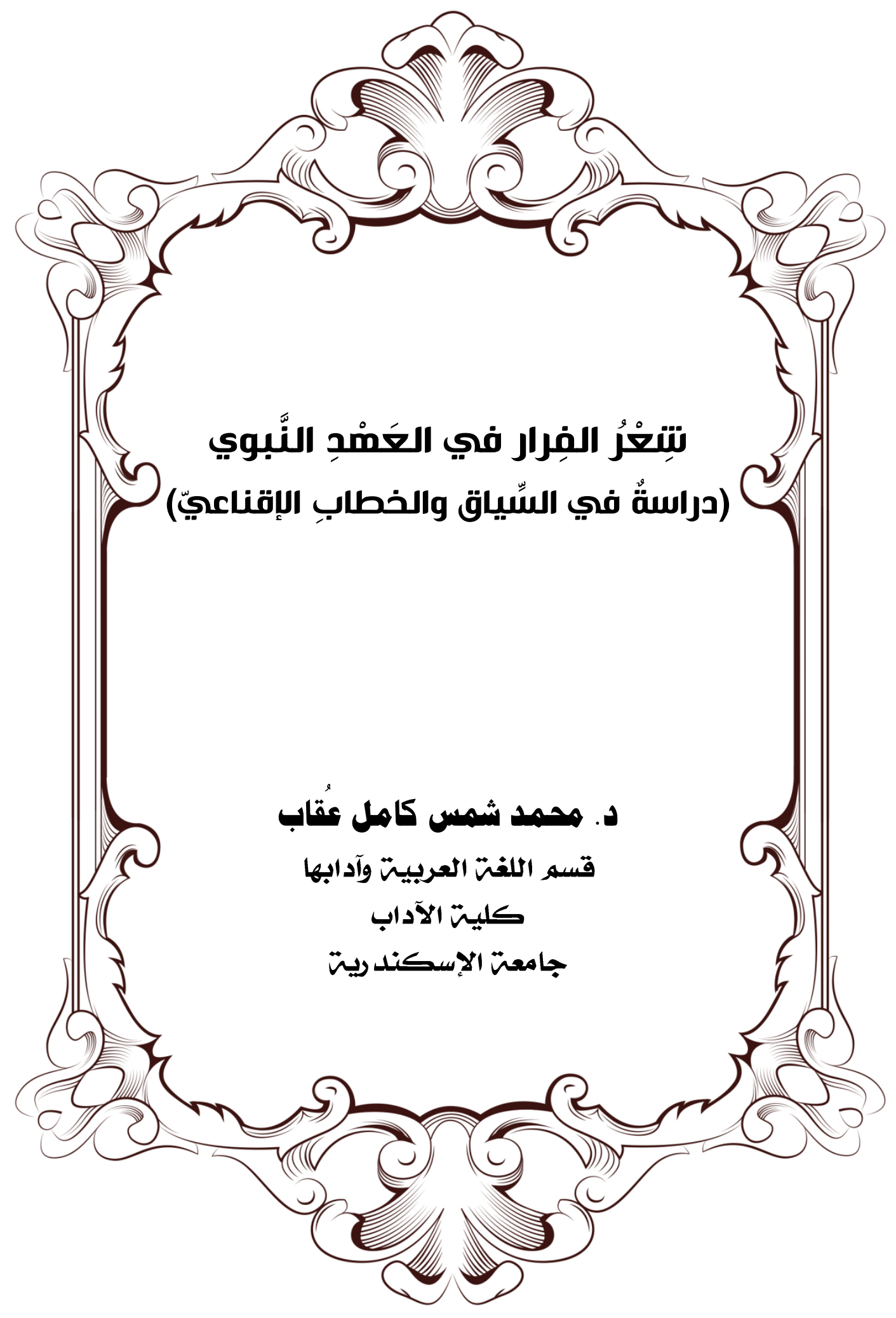



شـعر الفـرارفـي العهـلـ النبـوي (دراسـته فـي السـياق والخطـاب

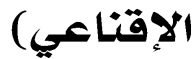

محمل شمس كامل عُقاب

قسهر اللغت العربيتّ وآدابها - كليتت الآداب - جامعت الإسكند ريت

- مصر -

mohamed.shams@alexu.edu.eg البريد الإلكتروني:

ملخص البحث:

يرصد البحث ظاهرةً مهمة من ظواهر الثِّعر في العهد النبوي، مثبتًا سَعَتَها ومـا أحدثته مـن جدالٍ حجاجيّ يصبو إلى الإقناع بـالطرق المختلفة. وهي تمنل ديوانًا كاملًا في موضوع فريدٍ مختلف.

لقد وقف البحث على إحدى عشرة واقعةً من وقائع الفرار في العهد النبوي، أي في نحو عشر سنين فحسب، ولّدت هذه الوقعات شعرًا كثيرًا من شعر الفرار •

إن مما يدل على قيمة ظاهرة الفرار كثرة الشعراء المشاركين فيها بين مهاجم منّّهم، ومدافعِ عن نفسه، وكثرة الخائضين في أمرها من غير الثعراء، والقيمة أن بعض هؤلاء الشعراء يحتاج إلى تتقيب وبحث عنه. وقد سلك هؤلاء

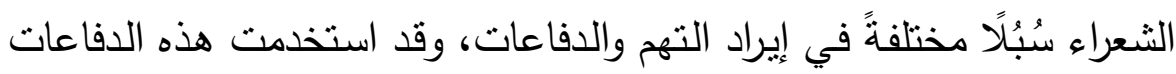
الحجج العقلية والعاطفية المختلفة، واتخذوا سبلًا مختلفة للتأثنر في المخاطبين نفسيًّا ومنطقيَّا، أو مغالطيَّا في بعض وله الأحيان. الكلمـات المفتاحيةة: الشعر في صدر الإسـام ـشعر الفرار ـ نظرية 


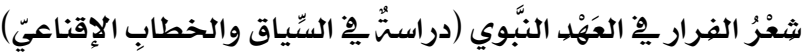

حوليت كليتا اللغتا العربيت بإيتاي البارود (العدد الثالث والثلاثون)

Desertion poetry during the Prophet's era

(Study of context and persuasive discourse)

Mohammad Shams kamel Uqab

Department of Arabic Language and Literature

Email: mohamed.shams@alexu.edu.eg

Abstract: This article deals with an important phenomenon of poetry during the Prophet's era, proving its capacity and the argumentative debate that aim to persuade in different methods. It represents an entire collection of poems in a different unique topic.

The article focuses on eleven incidents of desertion during the Prophet's era, that is, in only about ten years, and these episodes generated a lot of desertion poetry.

What indicates the value of the phenomenon of desertion is the large number of poets who participate in it, such as an accused attacker and this who defends himself, as well as the large number of those who are involved in its matter but they are not poets. These poets are that important to be studied deeply.

These poets have taken different paths in presenting the charges and defenses. These defenses have used different mental and emotional arguments, and they have taken different ways to influence, psychologically, logically or sometimes sophisticatedly, the addressees.

Key words: Poetry in Early Islam - Desertion poetry Arguments theory. 
لقد لفت نظري وأنا أقرأ كتاب (السيرة النبوية) لابن هشام (')، وفيه ذكرٌ

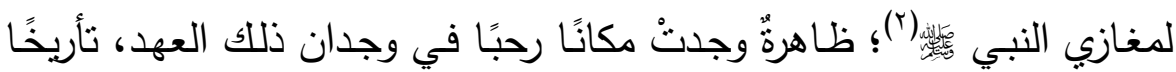
وشعرًا، ألا وهي ظاهرة الفِرار من القتال، وما قيل فيها من أشعارٍ بين الطرفين

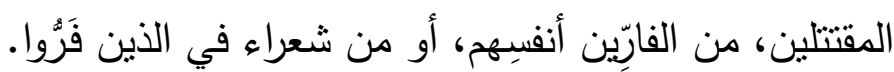

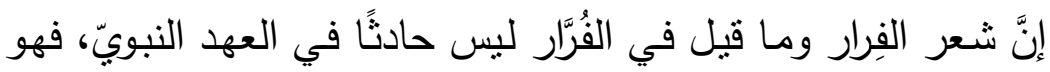
قديم منذ الجاهلية، ولكني أعدُه من الأغراض المهمَّة في شعر صدر الإسـام

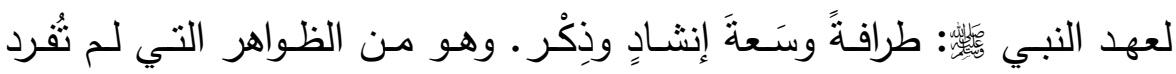
بحديث في فيما رأيته من كتب الدارسين، ففي دراستها وضع لبنةٍ جديدة في تاريخ الأدب في ذلك العصر ، وتسليطٌٌ للضوء عليها. ولعل أبرز ما يسترعي الاهتمام في هذا الشعر ما يرد فيه من الحُجج

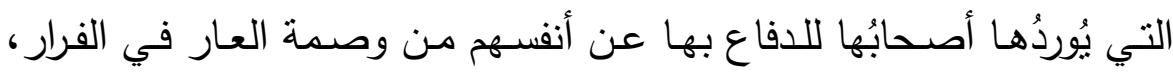

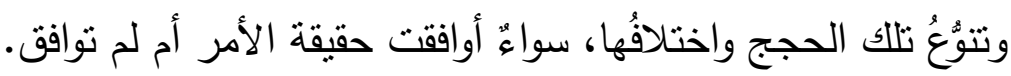
ولعلَّ عصدرًا لم بظفر بهذه الظـاهرة في شعره كمـا ظفر بها العهد

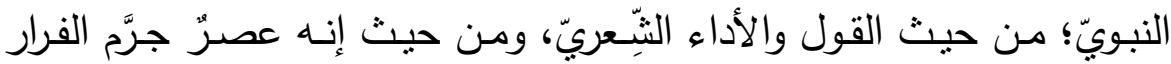
وحرَّمه، وهو كان مقَبَّاً عند العرب من قبل، موصومٌ صـاحبه بالعار والخزي؛ فاستحقَّتْ هذه الظاهرة أن ندرسها حينئز

(1) انظر : السبرة النبوية، لابن هشام، أبي محمد عبد الملك بن هشام بن أيوب الحِميري

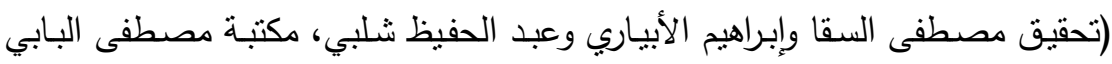

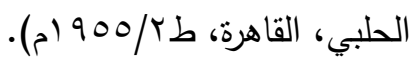

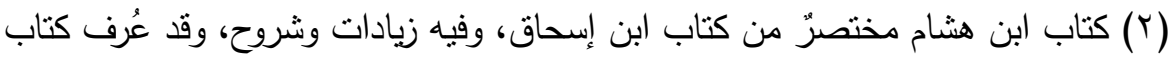

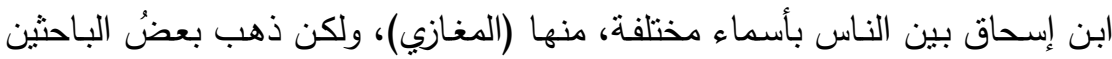

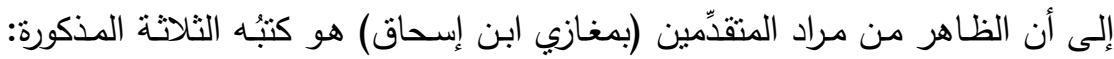

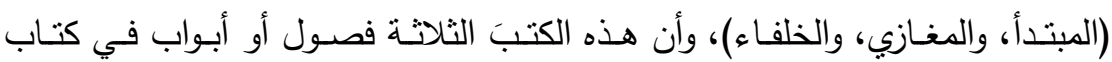
المغازي (انظر : رواة محد بن إسحاق بن يسار في المغازي والسير وسائر المرويات،

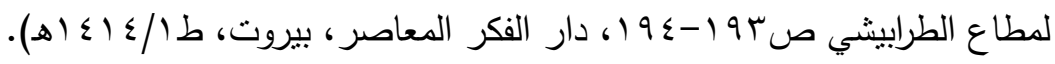


وقد رأيت أن هذه الظاهرة لهذا العهد حَريَّةُ بالدراسة في سياقين: سياق

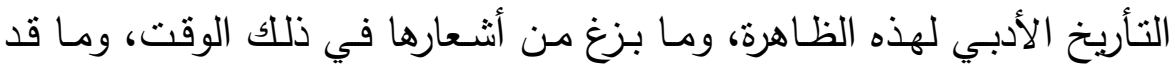
خلقَّته من آثارٍ في المجال الأدبي؛ وسياقِ تحليل مـا جاء في غضون هذا الثعر من خطابٍ إقناعيّ -وهو من أجلى خصائص ذللك الشعر - يُريد بذلك

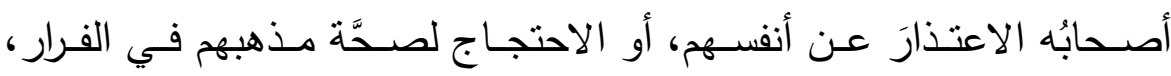
متّخذين في ذلك الوسائل التأثيريَّة المختلفة: الأسلوبية والعقلية والنفسية؛ تحليلًا يظهرنا على القُدرة الفكريَّة والفنبِيَّة لدى شعراء ذللك العهد.

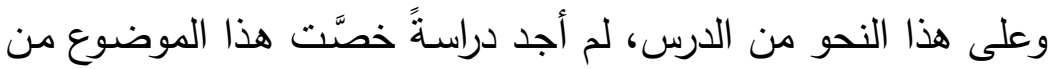
قبل، فيما وقفتُ عليه من البحث (1)، و الله أعلم. وخُطَّة البحث أن أبدأه بمفهوم (الفرار) في اللغة، ثم بتمهيد عن الفرار في الثعر الجاهلي، ثم حديثٍ عن الفرار في الإسلام وخطره وحُكمه.

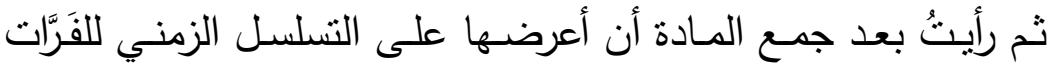
الحادثة في العهد النبوي، فَرَّة فرَّة؛ وهذا هو السياق التاريخي؛ فإذا ما عرض الخطـاب الإقتـاعئٌ في أي موضـع مـن مواضـع الثـعر ؛ وققت عليـه بالدرس

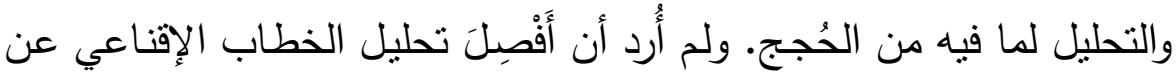
السياق التاريخي لكيلا أكرّر الأشعار في البحث؛ فيطول من غير كبير طائل،

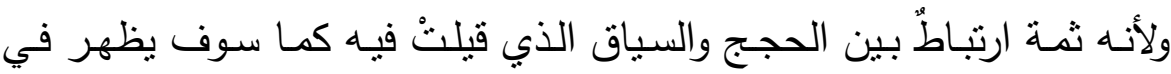
البحث.

فيكون البحث مستدعيًا في الدراسة منهجين: المنهج التاريخي، وذلك في دراسـة السياق، وأدوات مبحث الحِجاج الذي يمتاز بكثرة الحقول المعرفية

(1) مهـا كتب في شـعر الفرار ولكن في العصر الجاهلي: الفرار في الثـعر الجـاهلي:

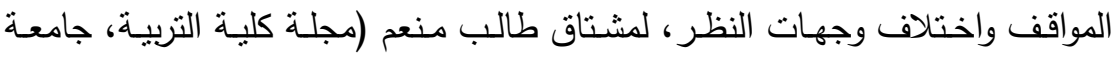

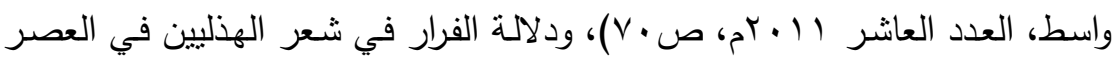

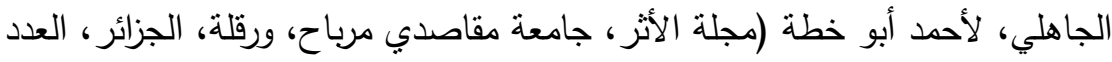

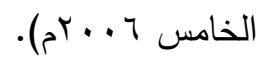


الني تتتاوله، كالفلسفة والمنطق واللسانيات ونظرية النواصل وعلم النفس وغير ذللك من الحقول. والمقاربة الحجاجية أوفقُ المقاربات لتحليل منل هذا النوع من الثـعر الذي يُعـالج مسألة الإقناع: إقناع الآخرين، وإقناع النفس في بعض الأحيان. ثم أختم البحث بخاتمةٍ بها أهم نتائجه. ولم أرد أن أترجم لكل شـاعر في البحث لكي لا تتنفخ الهوامش، بل اكتقيت بترجمةٍ مختصرة لبعضهم بما يخدم متن البحث وسياقه. وأيضًا لم أفيّرِ جميع ألفاظ الثـعر الغريبـة إلا ما وقر في قلبي أنـه

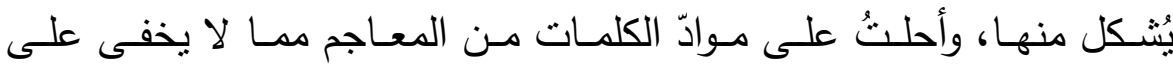
متخصص، وقد أحيل على بعض الكتب التي شرحت معنى الثعر . وينبغي أن أشنير هنا إلى أن أهم مصدرٍ من مصـادر الثعر الذي هو

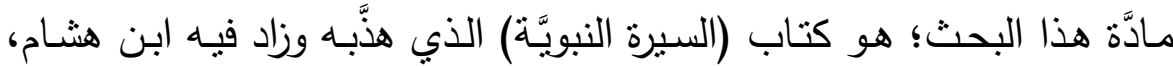

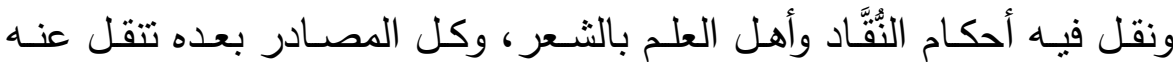
نصوص هذا الثـعر؛ وقد حرَصت على أن يكون الثـعر المدروس في هذا

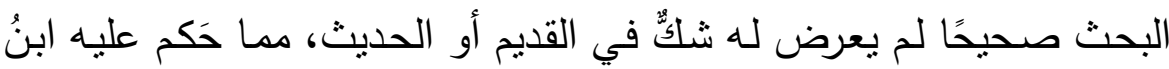
هشام أو غيرُه ممن نقل عنهم في كتاب (السيرة)، أو في غيره من الكتب.

\section{في التهَهُهوهر:}

يأني مفهوم الفرار في اللسـان العربيّ دالَّا على الرَّوغـان والَهَرَب ،

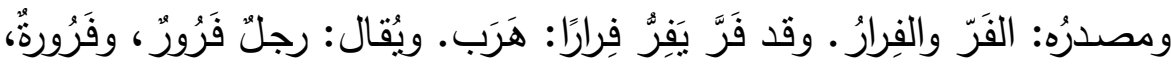

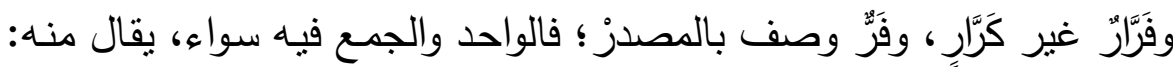

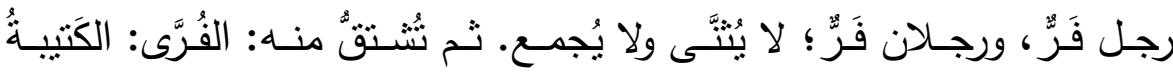

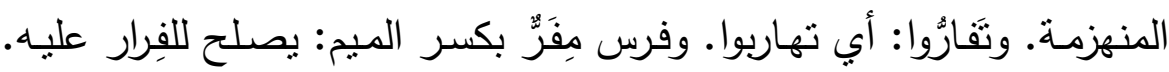

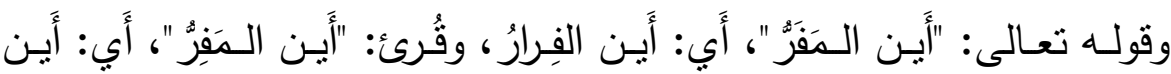




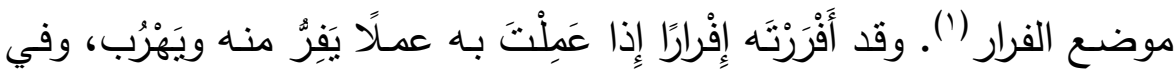
خبر عاتكة بنت عبد المطلب أنها قالتُ:

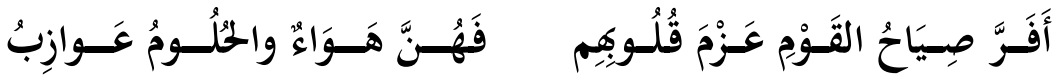

أَي حَتَاها على الفِرَار ، وجعلها خائفةً بعيدةً، غائبة العقول (r).

\section{(-)}

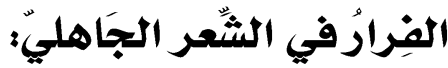

الفرارُ مذمومٌ عند العرب حتى قبل أن يُشترق عليهم نورُ الإسلام، إذ لم

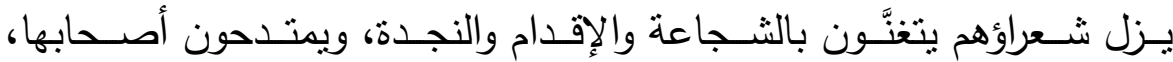
ويفتخرون بذلك في قصائدهم، كقول الحُصين بن الحُمام(ّ) يذكر إقدام قومهه،

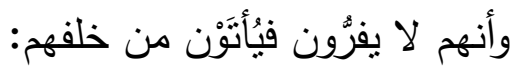

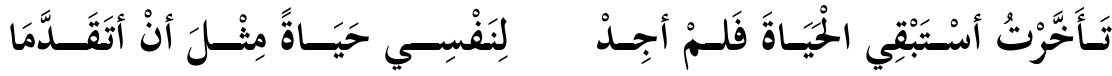

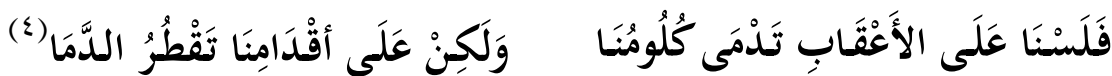

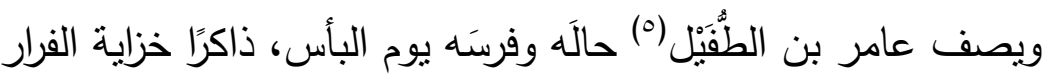

( (1) انظر : لسان العرب، لابن منظور، جمال الدين محمد بن مكرم بن علي الإفريقي، مادة: فرر 0.10 (تحقيق عبد الله علي الكبير وزميليه، دار المعارف، القاهرة).

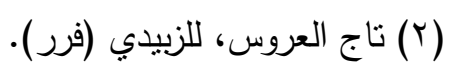

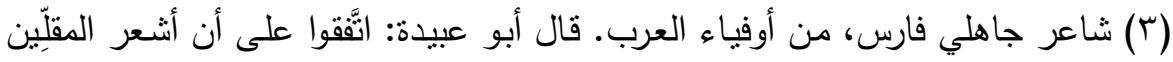

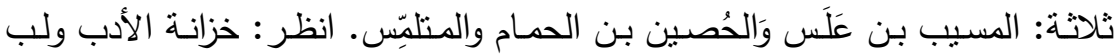

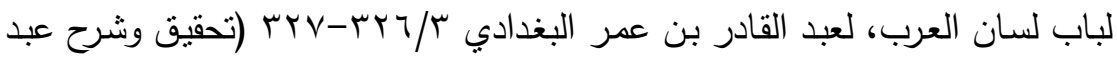

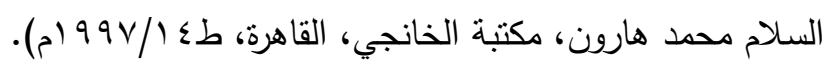

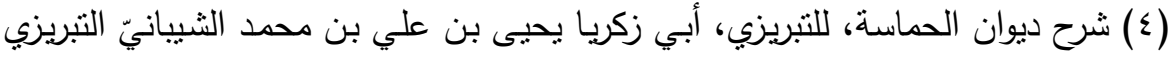

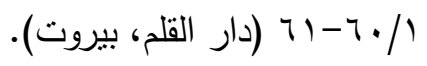

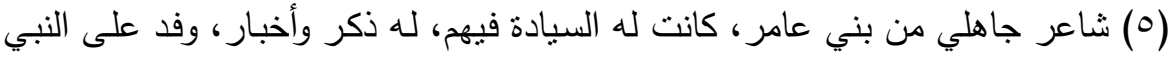

$$
\text { ) }
$$




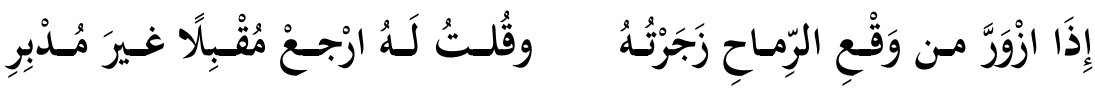

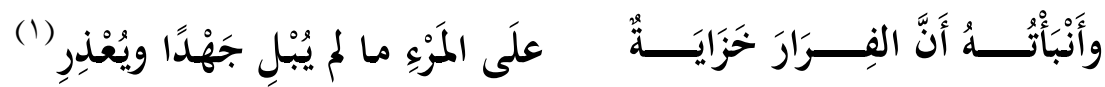

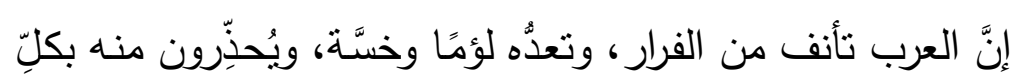

سبيل، ليس بالثـعر وحدَه، بل وجدناهم يصنعون هذا فيما وقع إلينا من قليل

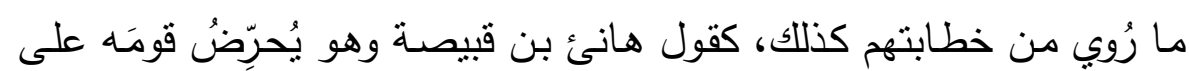

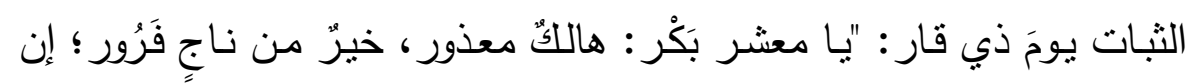
الحذر لا يُنْجي من القدر، وإن الصبر من أسباب الظََّّرَ. المنيَّة ولا الدنيَّة.

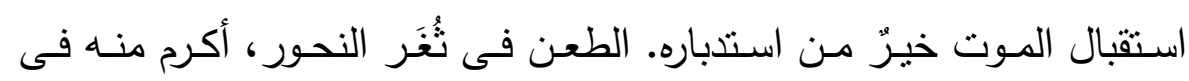

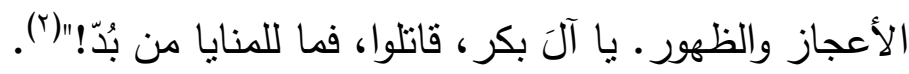

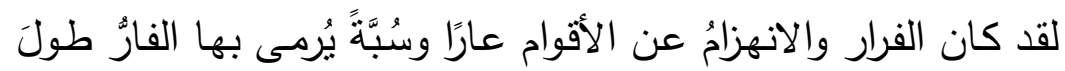
حياته، ولا يزالُ يُعيَّر بها عند العرب، ولا تُنْسى له. ولم يكن للفارِيِّن من حولٍ

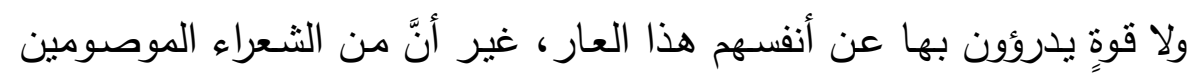

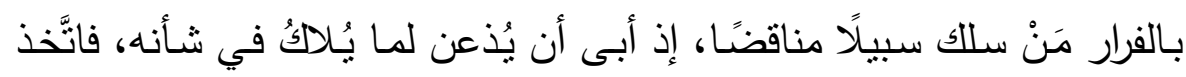

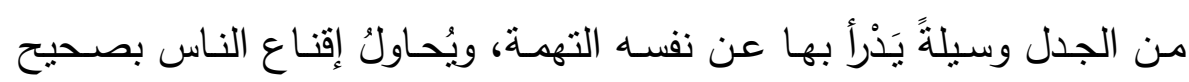

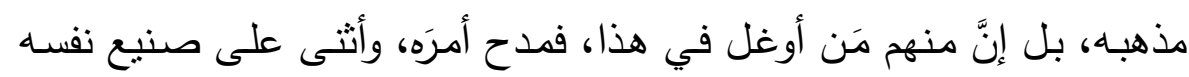

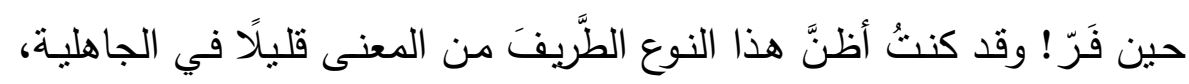

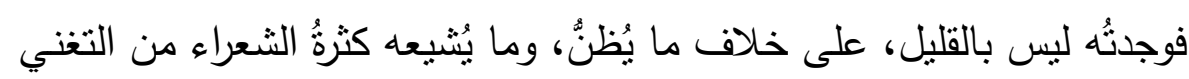
بالشجاعة والإقدام والاستبسال في المعركة، وقد تتبَّه الجاحظُ لهذا الأمر فقال: لهال

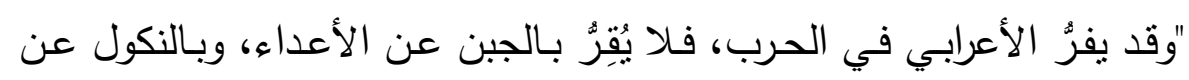

(1) المفضَّليات، للمفضل بن محمد بن يعلى الضبي ص آجس-r ب؟r (تحقيق وشرح: أحمد

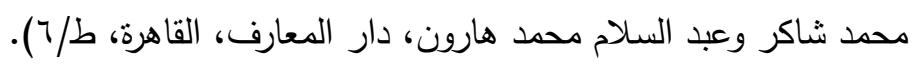

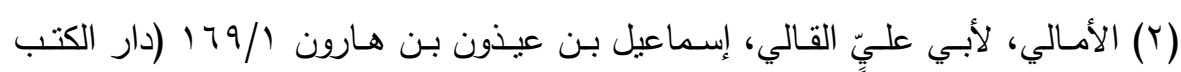

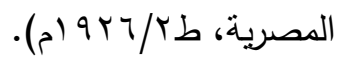


الأكفاء، بـل يُخرِّج لذلك الفرار معنى، ويجعل لله مذهبًا، ثم لا يرضسى حتى

يجعل ذلك المفخر شعرًا، ويشهره في الآفاق" (1).

نضربُ أمثلةًً لهذا الجدال الذي عُرض في الجهره في الجهلية في نحو قول أوس

بـن حَجَر وهو يـردُّ على مـن عيَّره في لقاء بني عَبْس، ولكنهه غيـرُ مـوقنٌ

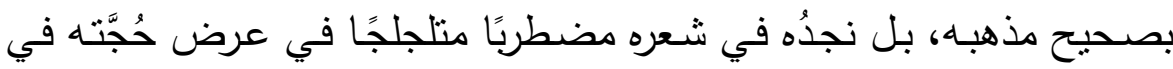

قوله:

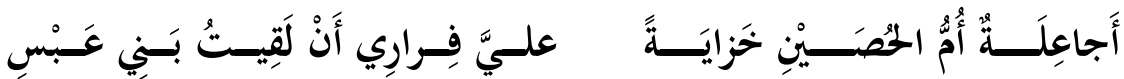

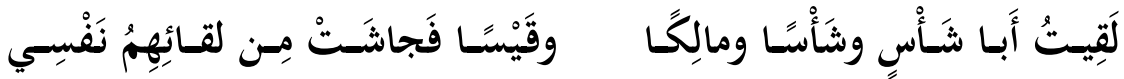

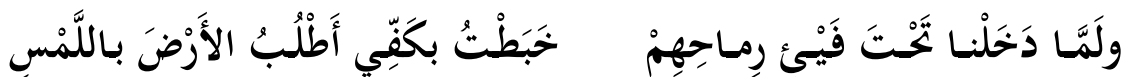

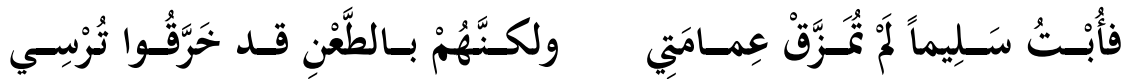

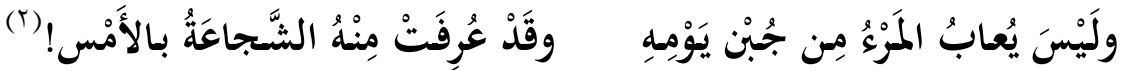

على أنَّ شاعرًا آخر هو سلمة بن الخرشب الأنماري يتعامى عن فَرَّته

ومـا تشتمل عليه من الخزي، فيجنحُ إلى مدح فرسـه التي نجا عليها، مدحًا

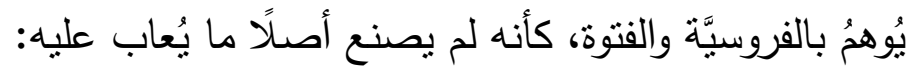

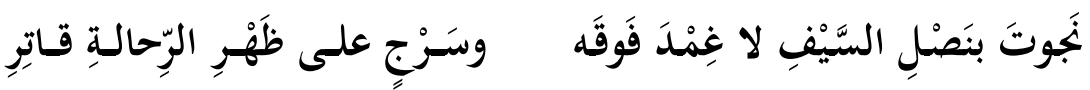

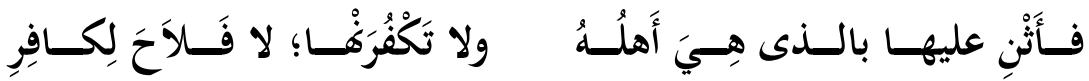

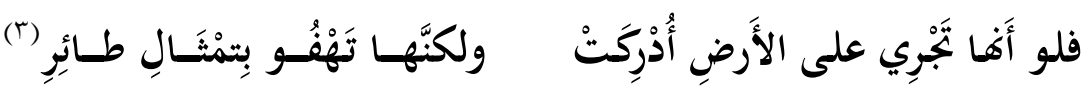

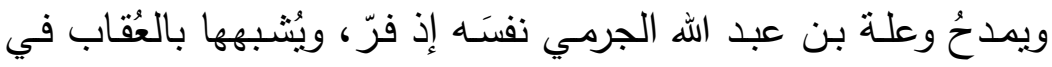

طيرانها وبأسها، وكأنه يصفُ هجومَه لا فرارَ، فيقول من شعرٍ له: له

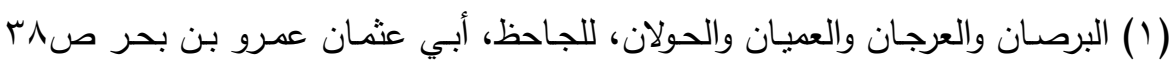

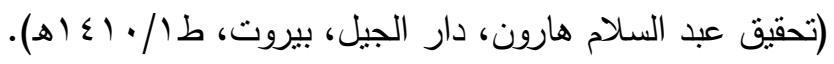

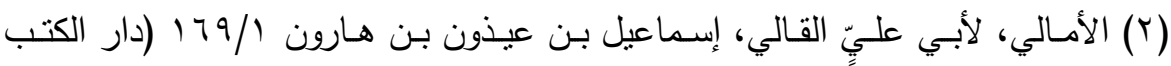

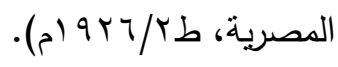

(ץ) المفضليات ص צr-r 


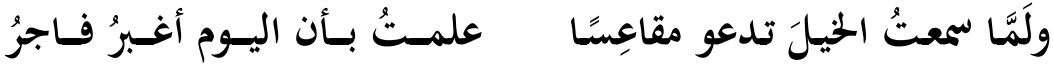

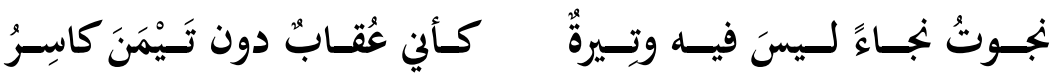
والتفسير عندي أنَّ الثعراء بَشْرُ من البشر ، يكرهون الموت حتى لو

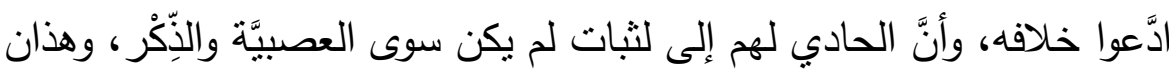

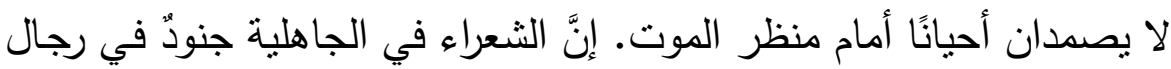

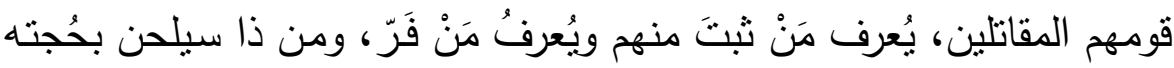

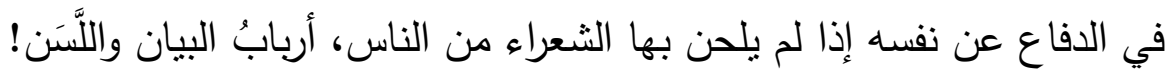

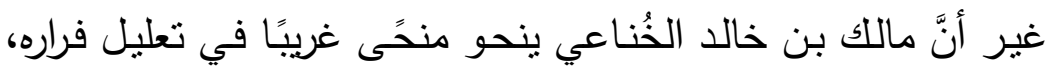
فهو قد فرَّ حين فر ليس خوفًا من الموت، بل من الأسر ؛ فإنه يأنفُ منه، ولا

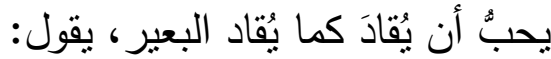

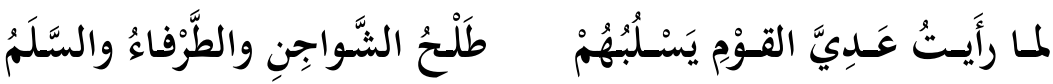

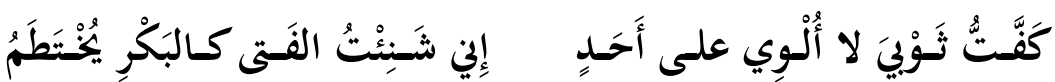

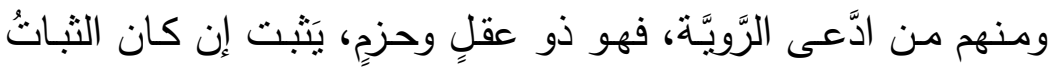

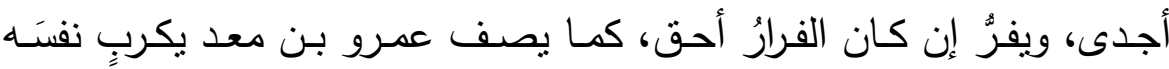

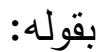

حســــذرَ المـــــوتِ وإِني لَفَـــــروزُ

حسينَ للـنفسِ مـن المـوت هُريسرُ

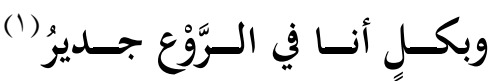

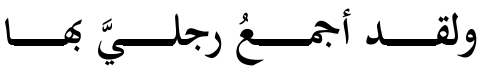

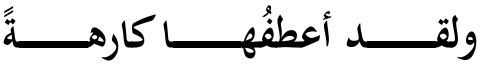

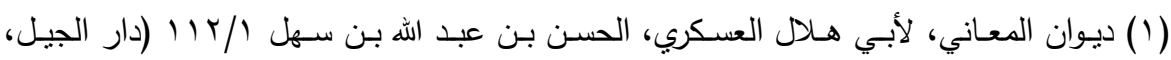

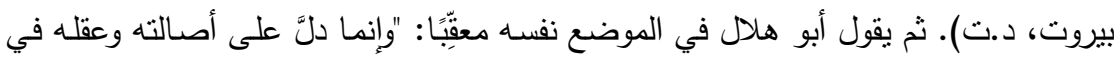
ثباته وقت الثبات، وفراره ساعة الفرار، وليس الثجاعة أن يحمل الرجل نفسه على الهلكة، إنما

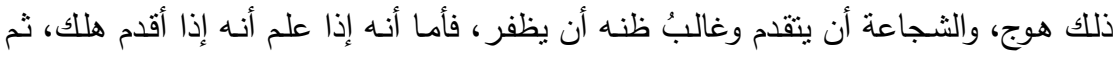

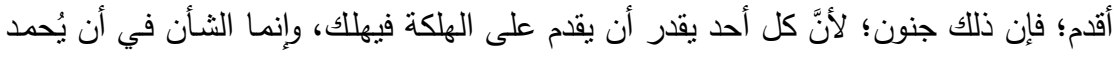

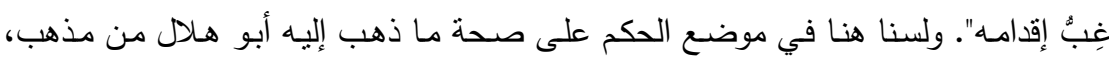
ولكننا بصدد الإثشارة إلى معنى من المعاني الدذكورة عند العرب في هذا الثأن. 
ويجمع ذللك ماللكُ بن أبي كعب في قوله:

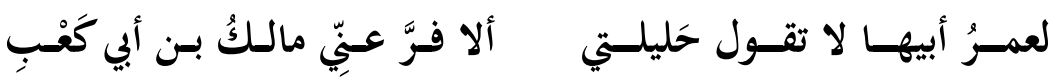

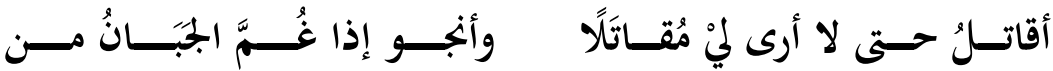

يقول: أنـا أهرب لأني شُجاع؛ لأنَّ الذي يُقتنل في مأزق هو الجبان الذي يُرْتج عليه! وهذا من عجيب المعاني، ومن قلب الحقائق من غير شك،

ولكنه الشعر .

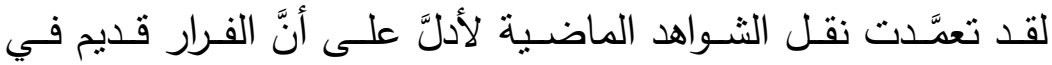

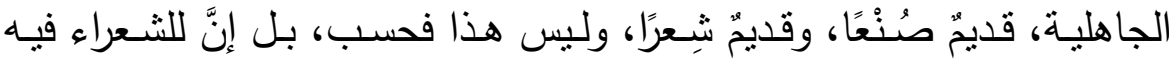
المذاهبَ في تسويغه أو الاعتذار عنه، أو المكابرة في جعله حصافةً وحِّمَة، وهذه ظاهرةٌ سلوكيَّة ينبغي أنْ تُبتَتَ في مكانها من فلسفة الأخلاق في بحث المجتمع الجاهلي، وفي بحث الأدب الجاهليّ كذلك، لا أقول إنها الأصل، بل بل كانت الثجاعة والإقدام والمحامـاة عن الثـرف والعرض والنفس والقوم هي الأصلـ، ولكنها ظـاهرةٌ كان لها وجود كمـا نقلنـا ذلك من أثـعار الجـاهليين

\section{$\{1$}

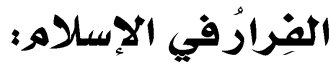

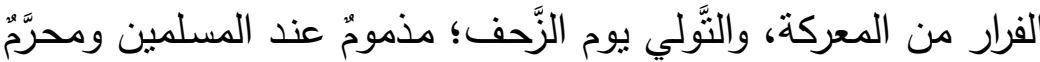

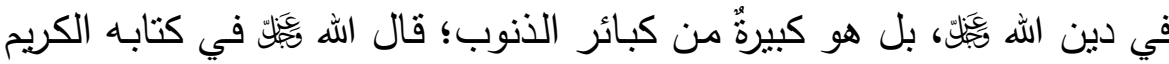

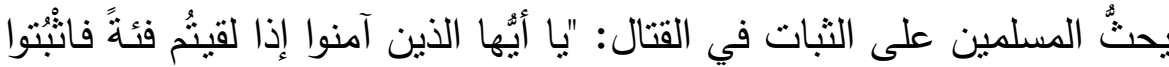
واذكروا الله كثيرًا لعلكم تُقلحون"(ז)، ويقول في آيـاتٍ أخرى محذِّرًا من الفرار وعاقبتِه، وعاقبتُه غضبُ الله: "يا أيُها الذين آمنوا إذا لقيتُم الذين كفروا زحفًا فلا

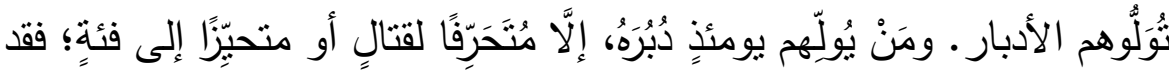

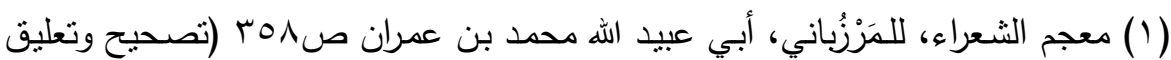

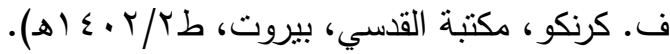

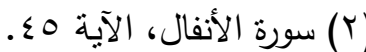




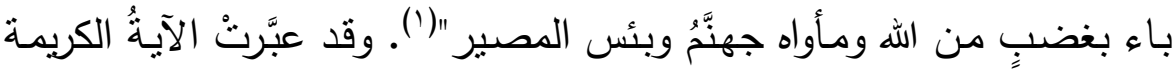
بلفظ (تولية الدُُّر ) وما يُوحيه من صورة الخزي والمهانة، تقبيحًا لهذا الصنيع، بهاه وتحقيرًا من شأنه.

إنَّ دواعيَ الثبات في القتال عند المسلمين أوثقُ من دواعي الجاهلية، فالمؤمن المجاهد في سبيل الله ظافرُ في كلا الحالين بإحدى الحُسْنيين: النصرِ

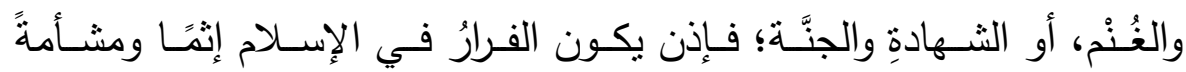

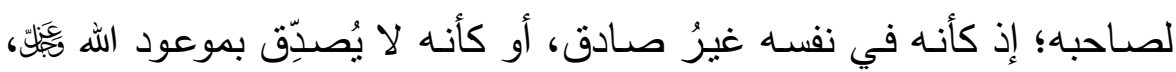
فكأنما قد ضعُف قلبُهه واهنزَّ إيمانُه ففرّ .

من أجل هذا يجد المؤمنُ الفارُ في نفسه ما لا يجده غيرُه من الضيق

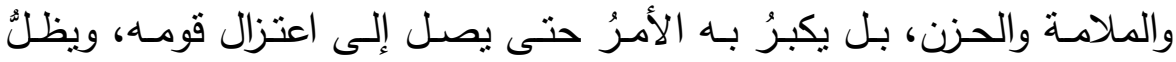

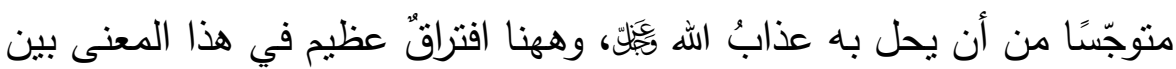
من يُحاجج عن فراره في الجاهلية، ومن لا يستطيعُ قولًا من المسلمين إذا هو فرّ ، إنه ليس بقبيل السفطة ذلك المسلمُ المجاهد في سبيل الله، فحاديه نُصرةٌُ

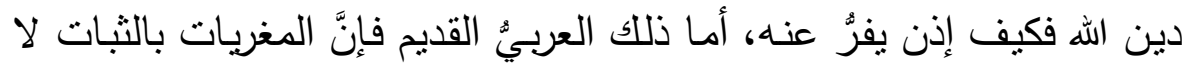

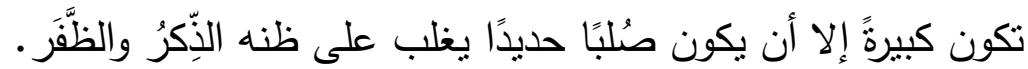
وقنْ على هؤلاء الجاهليين كفارَ مكة الذين حاربوا جيش المسلمين في صدر الإسلام، فهؤلاء أنشأوا أشعارهم ناريخيًّا في العهد النبويّ، إذا نحن أردنا تصنيف أشعارهم تصنيفًا زمنيًّا. إنـه إذن بـخلُ في إطـار دراستتا الأشـعارُ التي تتاولت تلك الظـاهرة لاى الفريقين: فريق المسلمين، وفريق المشركين، في ذلك العهد الزمني. على أنَّ الصراع الحربيُّ بين الفريقين لم يكن سبيًا في نتاج الثعر في هذه الظاهرة

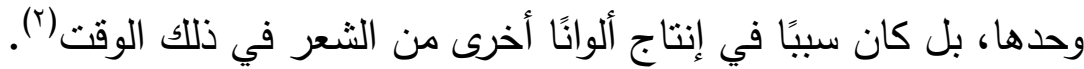

$$
\text { (1) سورة الأنفال، الآيتان: 10-17 (1) الظط }
$$

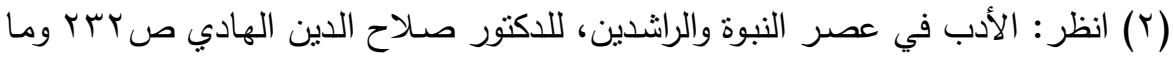

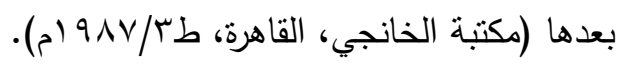


إنَّ دراسـة الثـعر في صـدر الإسـلام ينبغي ألَّا تقتصـر على أثـعار

المسلمين وحدَهم، بل بجدر أن تقصد إلى أشعار المشركين فتبحثَها كذللك(')؛ لكي يكتمل التصوُّر الأدبيٌّ عن العصر الإسـاميّ الأول في قضاياه وظواهره الثعرية، ذلك التصور الذي بقي منقوصنًا أو مشوَّهًا في كثيرِ من الأمر •

\section{$\{\hat{1}$}

\section{وَقْعَاتَ الامِرارن}

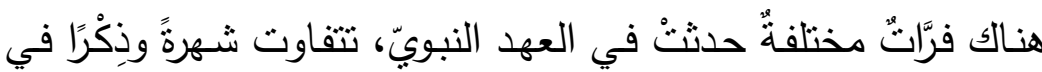
العـرب، ونتبـاين في مقدار التتاول الثـعريّ، وسـوف نرتبّهـا ترتيبًا زمنيًا في المجمل الأعمّ، ثم نحلِّل في خلهل ذلك الخطاب الإقناعي الذي يردُ في تلك الأشعار ، ونفصِّل القول فيما استعمله الثعراء فيها من الحُجج والمدافعة.

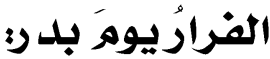

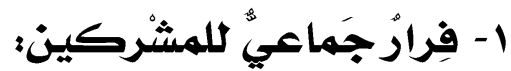

أحدثتْ غزوةُ بدرٍ (سنة بهـ) فخرًا عظيمًا عند الثـعراء المسلمين، وتعبيرًا

دائمًا لقريش، ولا سيّما من رُمسي بالفرار منهم ذلك اليوم، واتخذ شعراء المسلمين هذا الفرار مطيَّةً هيَّنة يخدشون بها بَطَرَ قُريشٍ ورجالاتهم حينًا بعد حين. لقد ذهب حسَّانُ بن ثابتٍ إلى أن الفرار يوم بدرٍ لم يكن فرار أفرادٍ، بل فرارًا جماعيَّا! وراح يذكر أسماء الفارِِّن من قريشٍ واحدًا واحدًا، منلذِّذًا بهجائهر، واصمًا إيـاهم بالعـار، معبّرًا عن ذلك بألفاظٍ مـن وادِ واحد، مـرةً بلفظ (الفرار)، ومـرةً بلفظ

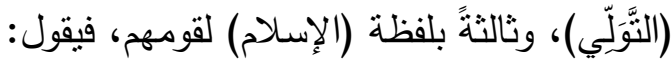

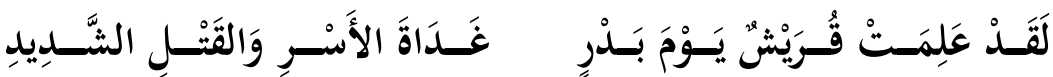

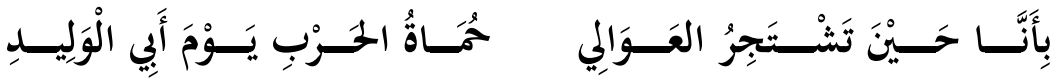

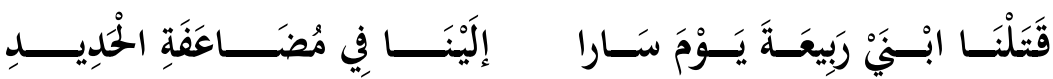

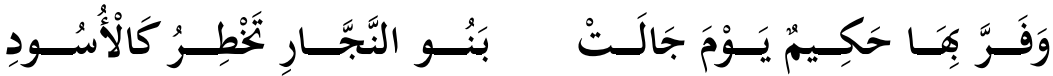
(1) انظر: الثعر العربي في القرن الأول الهجري، للدكتور محمد مصطفى هدارة صVV (دار العلوم العربية، بيروت 


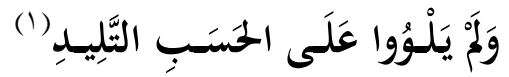

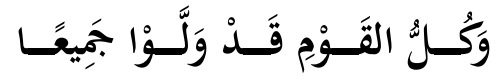

لقد سمَّى حسَّانُ قومًا من الفارِِّن يوم بدر، في سياقٍ لا يُرادُ بـه التحديد

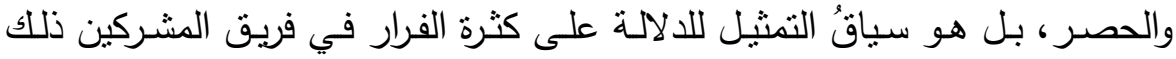

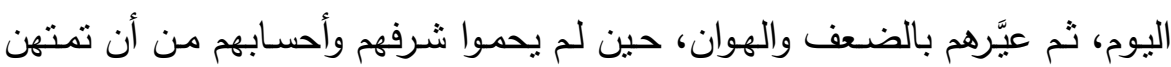
بسُبَّة الفرار .

وما زال بهم يذكر نقيصنَّهم، ويُضيِّق عليهم بها في قصيدة تلو قصيدة، وهجاءٍ بعد هجاء، ولفظةٍ من ألفاظ المهرب لَفقَ لفظة، فقد ذكر في الأبيات السابقة:

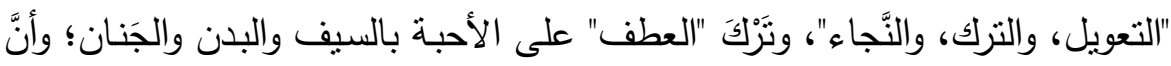

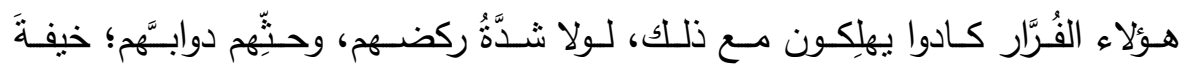
المسلمين، فهو يذكر ذلك في قصيدةٍ أخرى له فيقول:

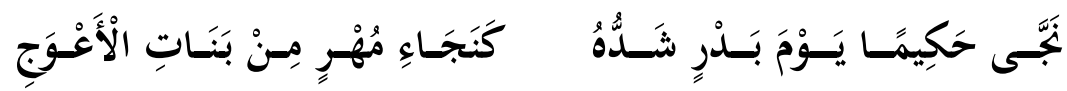

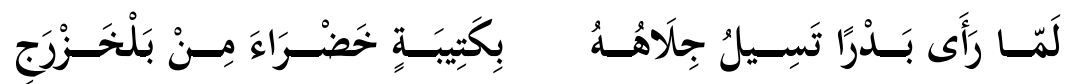

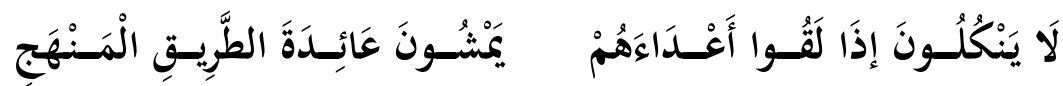

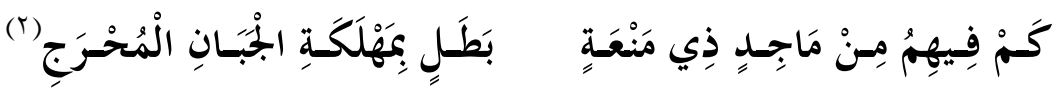

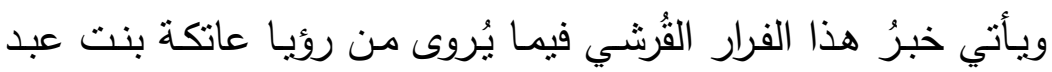
المطلب قبـل بـدر، مـن طريـق الزبيـر بـن بكـار عـن مصـعب بـن عبد الله

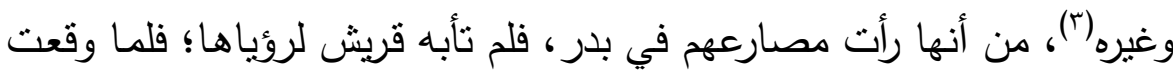

$$
\begin{aligned}
& \text { (1) السيرة النبوية r/ 19. }
\end{aligned}
$$

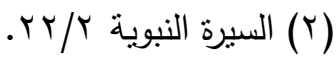

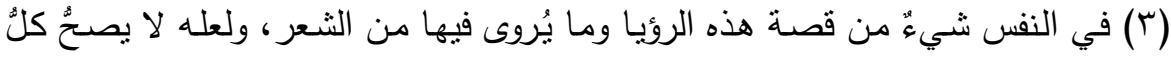

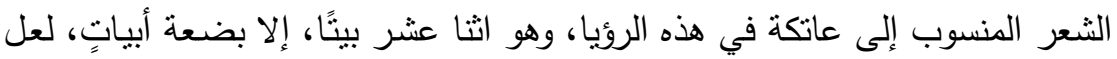

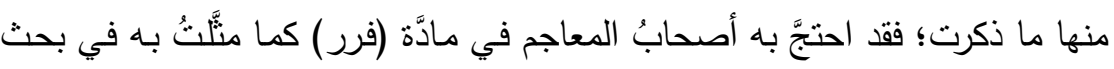
معنى (الفرار ) في مطلع هذا البحث. فئ. 
المصيبة بقُريش، وأتى الخبرُ أهلَ مكة؛ قالت في صدق رؤياها وتكذيب قُريشٍ

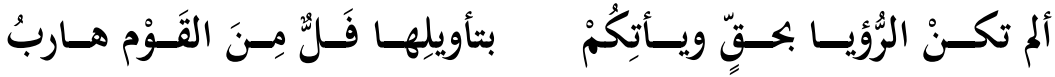

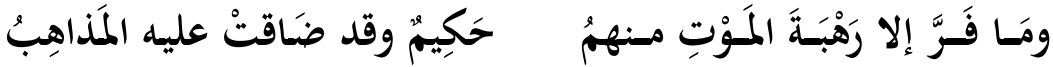

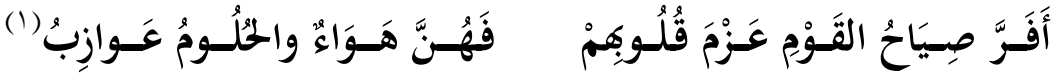

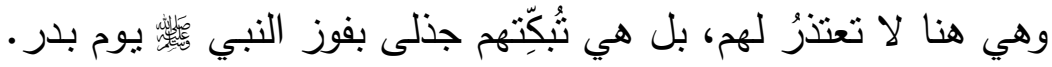

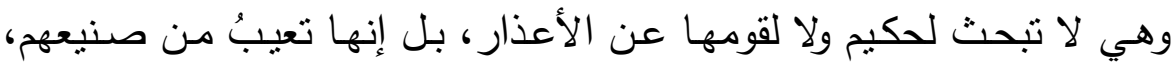

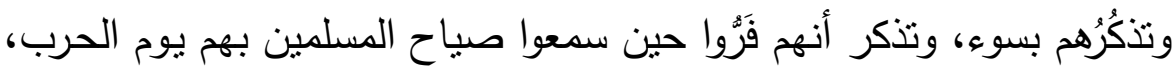

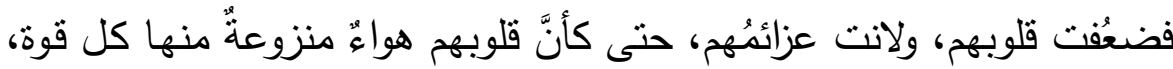
أو كأنَّ عقولهم قد طانتُ فلم بعدْ فيها رَثَدْ.

والعجيبُ أنَّ الوصم بالفرار في حقّ المشركين لم يأت من المسلمين

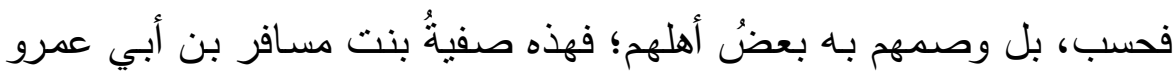

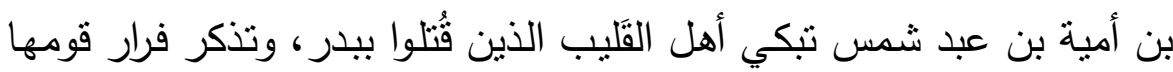

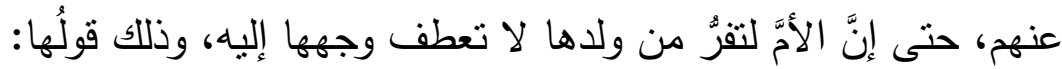

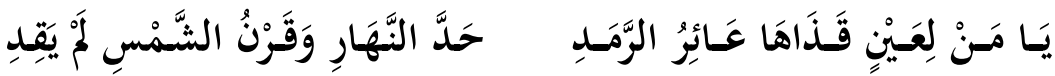

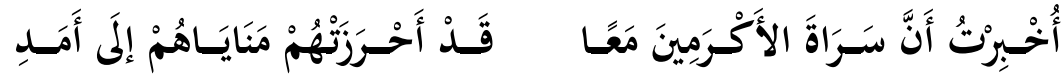

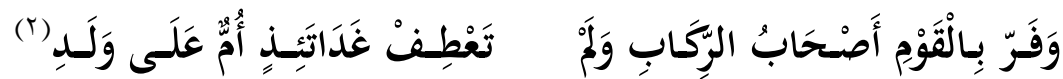

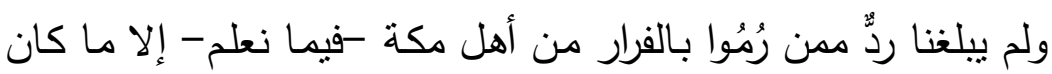
من أمر الحارث بن هثام، الذي فرَّ عن أخيه أبي جهلٍ وقومِه.

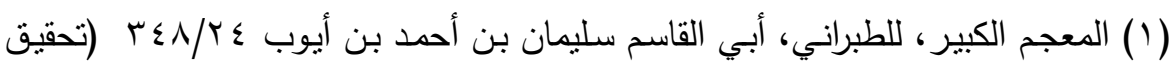

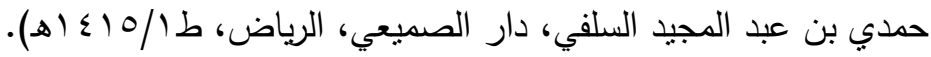

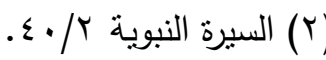




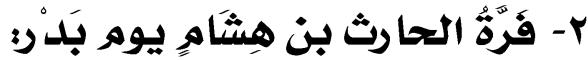

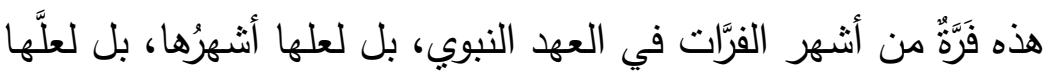

أنــهرُ فَرَّةٍ في تاريخ الأدب العربيّ، وذللك لسُمعتها التي طـارتْ في العرب، فتلقَّها شعراءُ المسلمين كحسان بن ثابت، الذي ما فتئ يذكرُها ويُعيذُها في كل

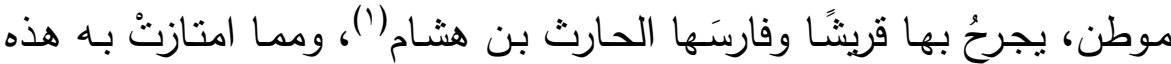
الفرة عن سواها أن الحارثَ صاحبها شاعرُ ، وقد دافع عن نفسه هجومَ حسان؛

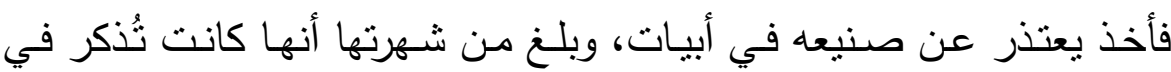
أشتعارٍ أخرى في غير معرض الهجوم والصَّدّ. ومع أنها كانت من فَرَّات المشركين في يوم بدرٍ ف فإننا نُفردها بحديثٍ خاصِّ بها لقيمتنْها الأدبيَّة والتاريخيَّة. يصفُ حسانُ مشهد هَرَب الحارث بن هثام في غزوة بدر (سنة بهـ)

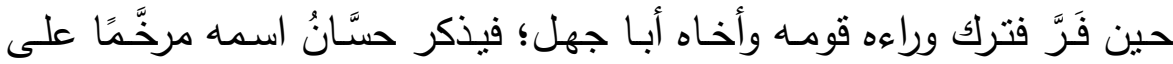

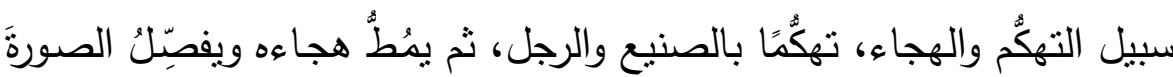
الثـعريَّة، وكأنـه يعرض لحظـة فراره بالحركة البطيئة؛ ليبالغ في إذلال نفس الحارث، وليُيْتي أثزهـا في الثـعر أكبر قدرٍ ممكن، وأطول وقتٍ مستطاع،

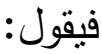

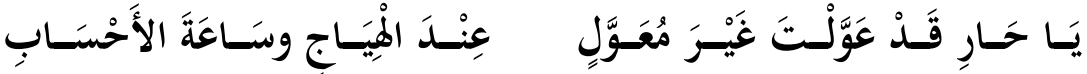

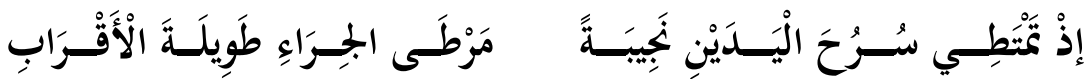

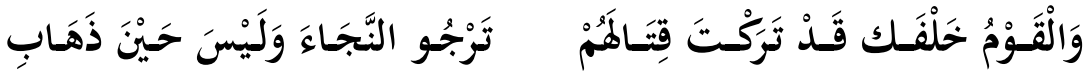

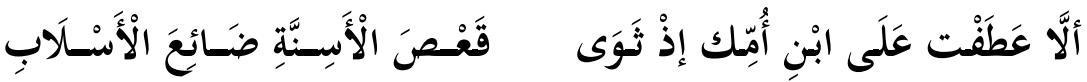

( (1) هو الحارث بن هشام المخزومي، شاعر قرشي، شهد بدرًا كافرًا مع شقيقه أبي جهل، وفرَّ حينتئذ وقد قتل أخوه، فعُيِّر بها. أسلم يوم الفتح وحسن إسلامه (انظر : الاستيعاب

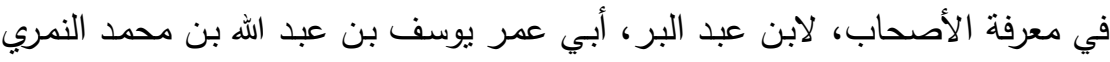

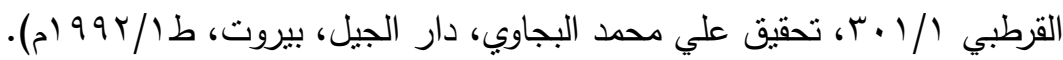




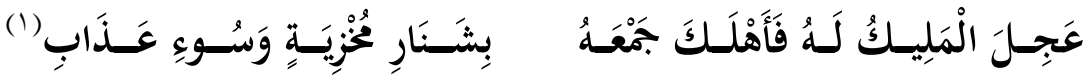
وحسان يصنع ذلك بالحارث بن هشـام على الخصوص لأنه شاعرٌ ،

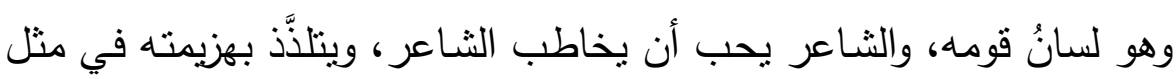
هذا المقام الحربيّ، الذي انتصـر في السِّنان، فبقي أن ينتصـر فيـه اللسـان. ولأنه أخو أبي جهل، وأبو جهلٍ هو عدوٌُ الله، وداعية قريشٍ إلى الثبات على

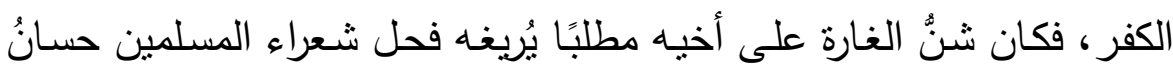
في تلك الساعة. ولذلك لا عجب حين نراه يُعيده، ويلوكه بلسانه كلما سنحتْ له فرصـة؛

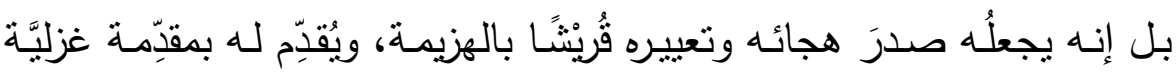
طويلة، من أحسن مقدِّمات حسان في قصائده، كأنه يتغنَّى بالنصر ، ويُغنّي منتشيًا بذكر المحبوبة، ويشمتُ بفعل الحارث، ويضحكُ مما صنع، فهو يبدؤها

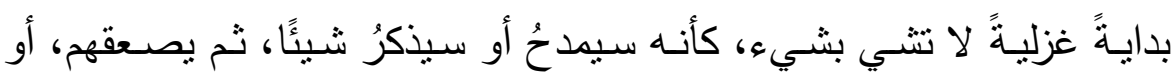

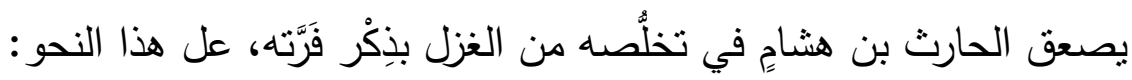

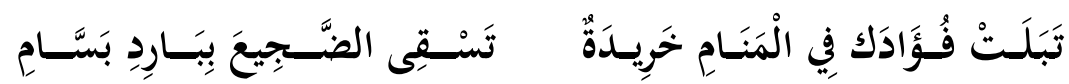

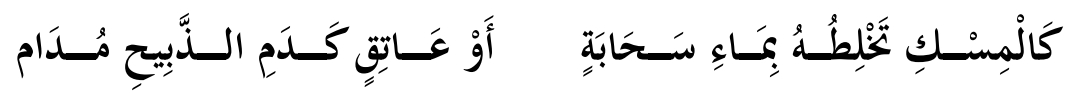

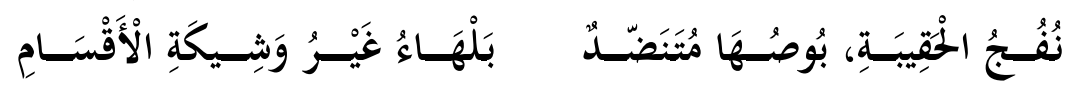

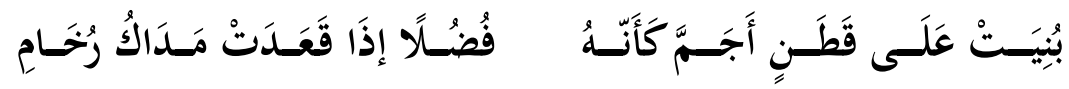

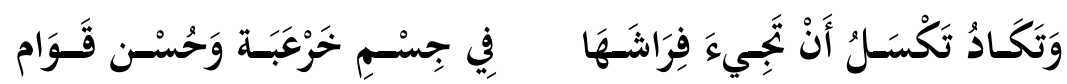

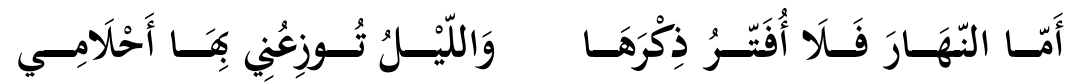

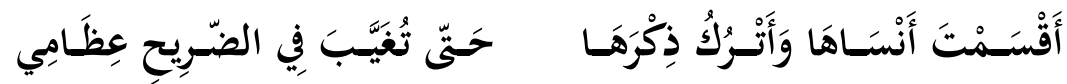

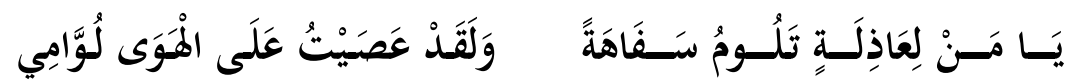

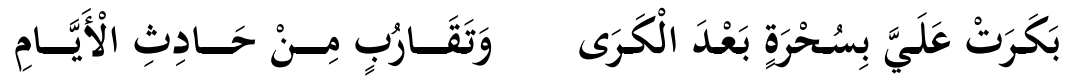




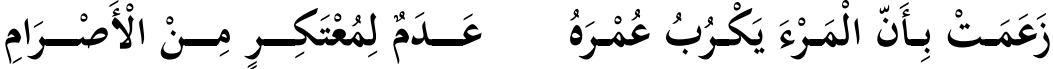

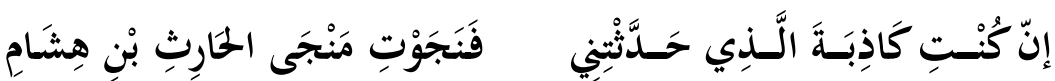

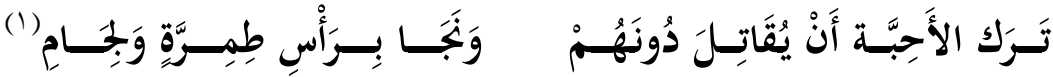

إنه هجومٌ مفاجئ، بعد هذا الغزل الجميل، وهو غزلٌّ لا نظنَّهُ خالصًا

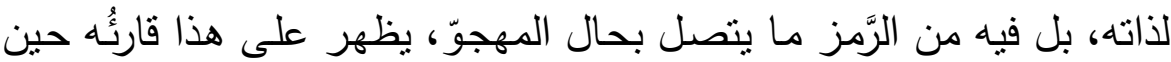
يقرأ الهجاء، ثم يعيد قراءة القصيدة بغزلها من أولها؛ إذ هو يُعرِض هفي في رأينا-

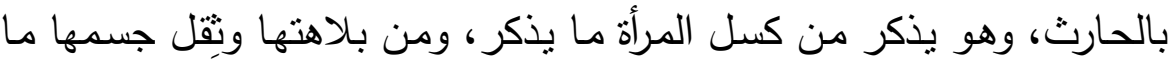

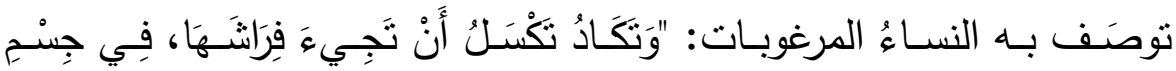

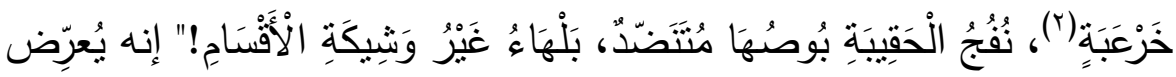
بالحارث؛ فإذا كانت هذه الصفاتُ من جمال المرأة عندهم؛ لإنها مقبوحةُ إن وُصم بها رجل من الرجال.

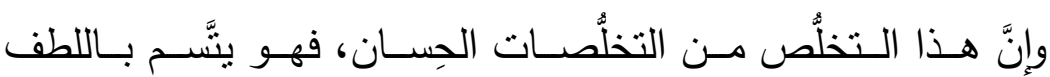
والرشاقة، وهو مدهِشٌ؛ إذ ينتقل من حديث المرأة إلى حديث الفرَّة، وهذا مما يَكتب لقصيدته الذيوع، ويدمغُها بالعَجَب.

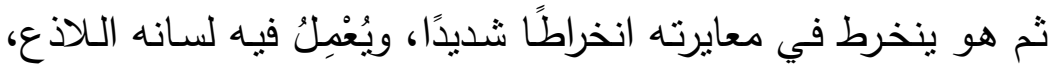
ويُفصِّل في طريقة فرَّته، ويُقبّح صنيعه؛ إذ كيف يترك أهلَه صَرعى، ويركض بفرسـه، التي لولاهـا لطُحن، ثم يأخذ مـن هذا خيطًا -كمـا يصنَع الثـعراءلينسج به مديح المسلمين، والهزج بانتصارهم، وبنصر الله لهم، في خـلال سلقه

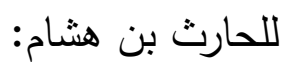

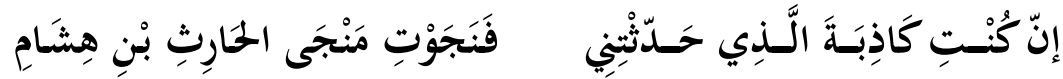

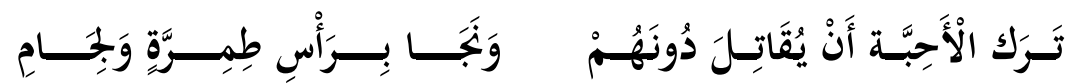

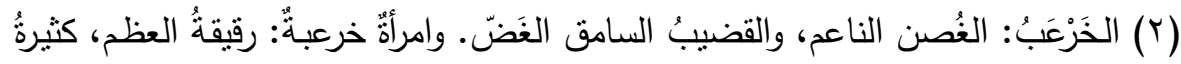
اللحم، ناعمة (انظر : لسان العرب: خرعب). 


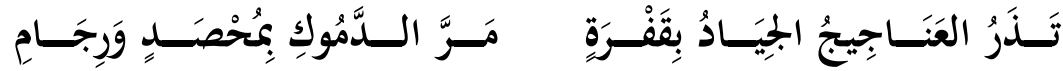

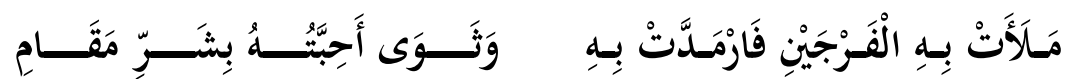

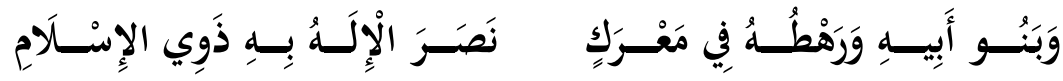

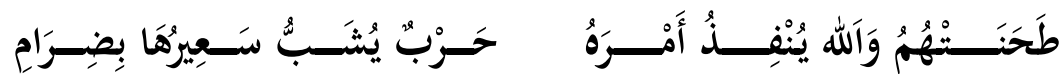

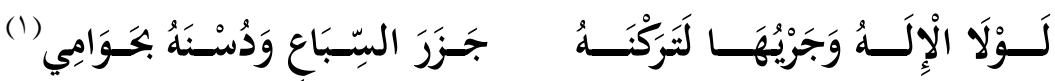

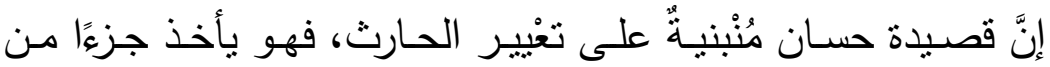

صورة هذا الفرار، ويبني عليه أجزاءه في هجاء الحارث بن هشام، أو مدح جيش المسلمين الثابتين، في عملٍ فَنٍِّ محدٍَِّ، واضح المعالم في ذهن الثـاعر الفنَّان. وهو في هذا يُطيل من ذكر هذه الحادثة، ويمطُهّا؛ إيذاءً منـه لنفس

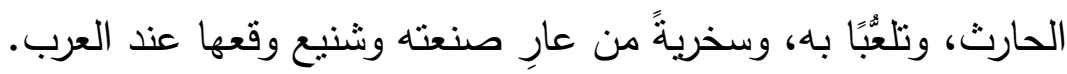

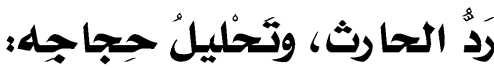

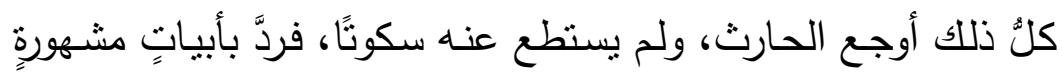
كذلك، يعتذر فيها عن فراره، ويذكر أسبابه، ويُدافع عن نفسـه سيلَ السِّهام

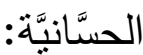

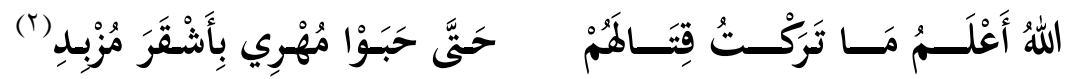

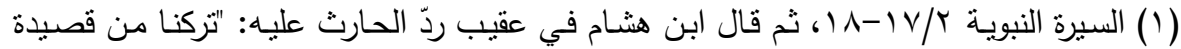

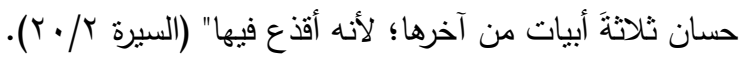

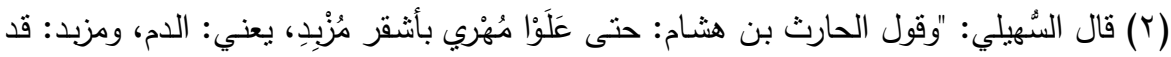

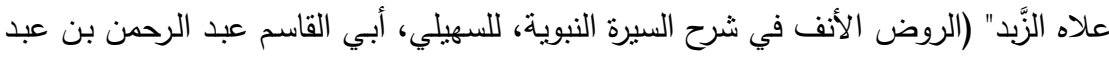

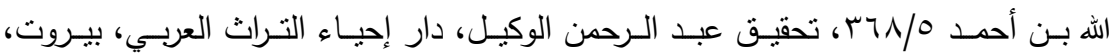

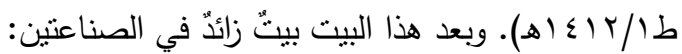

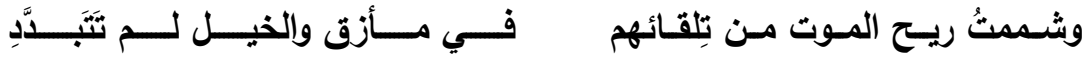
ثم قال أبو هـلال بعد إيراد الأبيات: "وهذا أول من اعتذر من هزيمـة رويت عن العربت

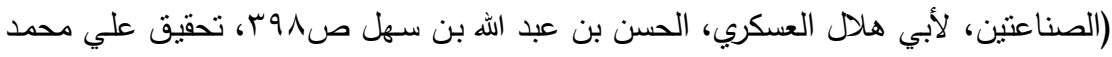

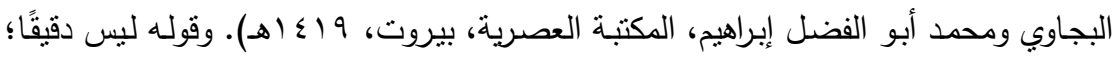
فققد نقلنا من قبل في هذا البحث مَنْ اعتذر من فراره من شعراء الجاهلية. 


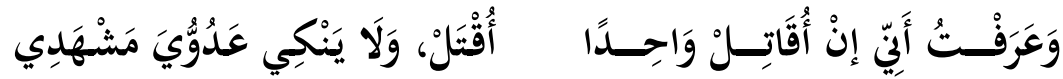

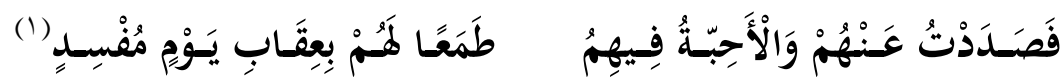

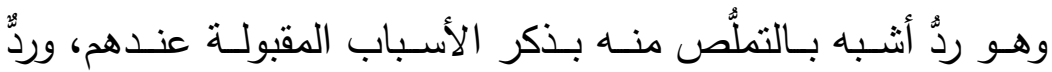

بالأمانيّ التي لا وجود لها في أرض الحقيقة، ولكنَّ الحارث ساق ردَّه بطريقته الفنيَّة، وهي طريقةٌ تعتمد على التجهيز والترتيب المعَدِّ من قبل، وبيان ذلك أنه

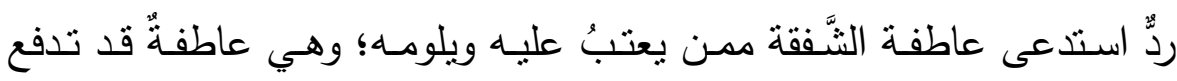
اللائم إلى أن يغفر للمذنب في بعض الأحيان. البداية بقوله: "الله أعلم"، بدايةٌ

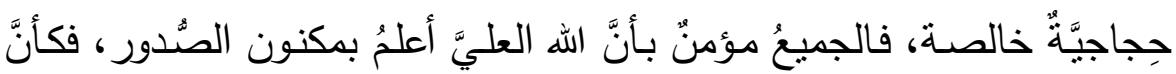
الثـاعر يقولُ: لا أُعاملكم أنتم، بل أعامل الله، وأنـا لم أكذب فيما أقول، والله

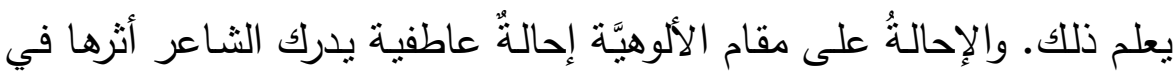

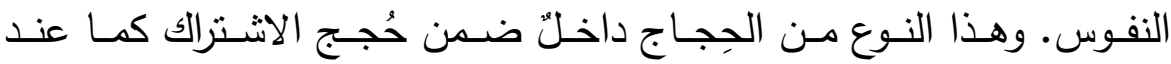
بروطون (r)، أو (الثَّهادة) كما عند أرسطو (r). إذن هي بدايةٌٌ تلامس القلوب وتستجلب العاطفة، وتستمطر منهم تصديقه.

يقول: "قاتلتُ حتى الموت، حتى تلوَّن مُهري بالدم المنتثر الذي علاه الزبد،

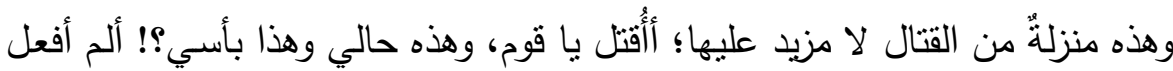

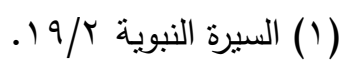

(Y) نستـعي حجـ الاشترالك عند بروطون: "المعتقدات أو القيم المشتركة مـع المتلقي،

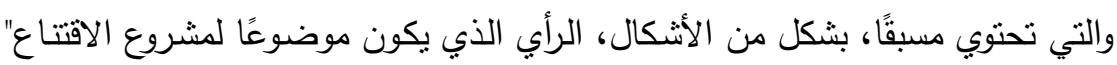

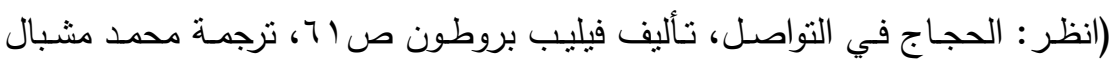

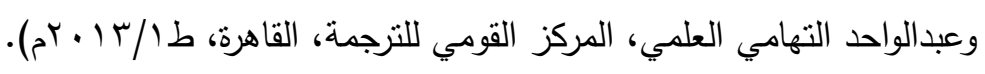

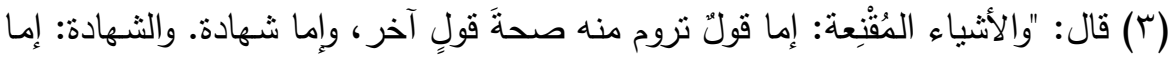

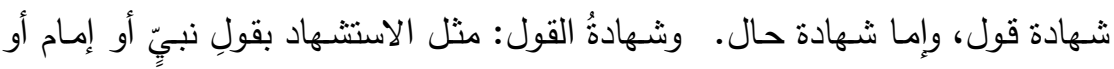

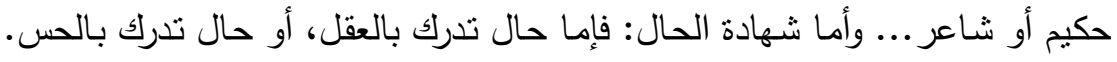

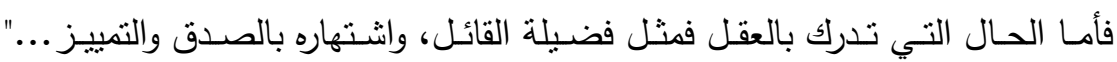

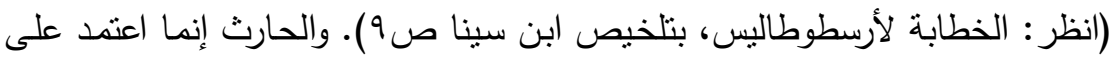

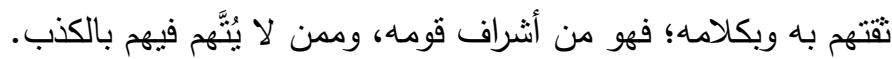


من أمور القتال ما يشفعُ لي؟"، وهو هـنـا يُحرِّك عاطفةً الثفقة فيهم، بل عاطفة

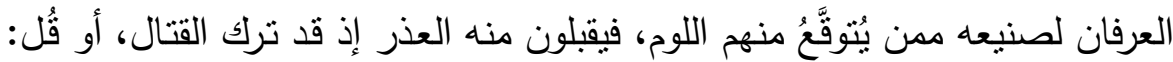
توقَّت عنه.

ثم هو في خـلال ذللك يقلب القضية، فيجعل مـن التههـة سبيلًا للدفاع،

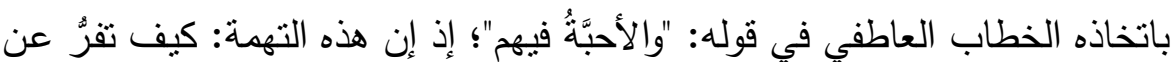

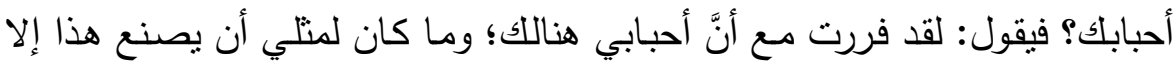
لثدة الموقف؛ لأن مثلي ما كان له أن يفرَّ إلا لما لا يُحتمل أو يُطاق. لقد عمد الثـاعر إلى حصر المعنى في هذه الصـورة: صـورة المهر

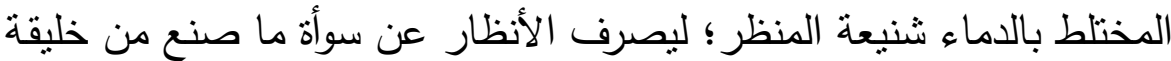

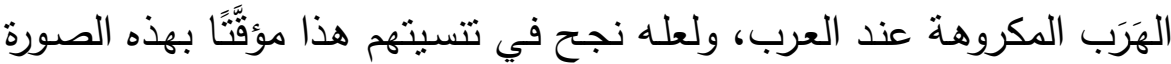

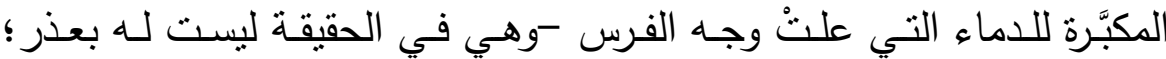
فالقتال جميعُه لا يخلو مـن الدماء- وهـو مـا يُسـَّى في المحاججـة بطربقـة

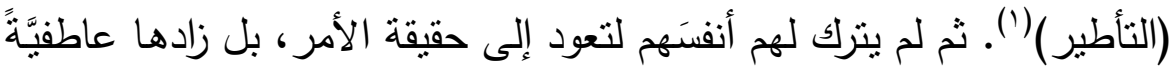

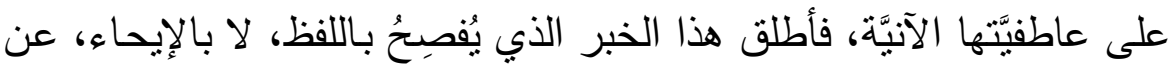

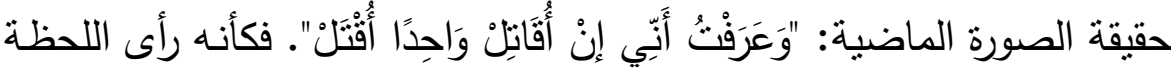
مناسبة -والقوم فيما هم فيه من الانشغال بصورة المهر المضرَّج- أن يبوح بما كان يخاف أن يبوحَ به من قبل، فلعل القوم عاذروه حينتئذ، أو لعلَّهم لن يلتفتوا

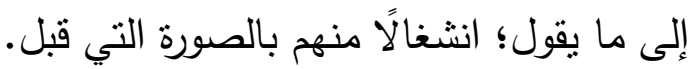

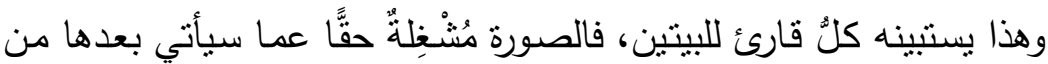

(1) وهي تقوم أساسًا على "عرض الواقع من وجهة نظر معينة، بتفخيم بعض المظاهر

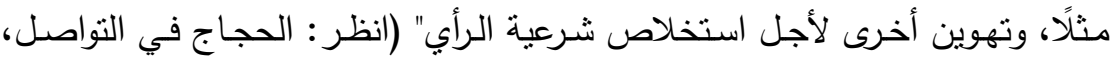

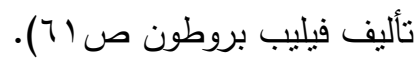


لقد وُفِقِق الحارثُ في إيراد هذه الحُجَّة بهذه الطريقة، أو وُفِّق في الدفاع عن صنيعه في هذا الثـعر ، بغضِّ النظر عن حقيقة صحة مـا صنعَ في

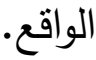

ثم أخذ الثـاعر يتسلسل في الحُجج، بحجةٍ أخرى مستولدةٍ من هذه

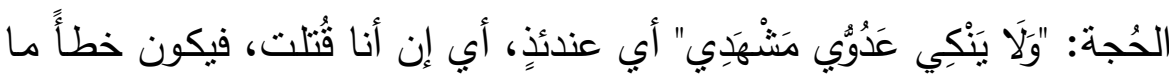

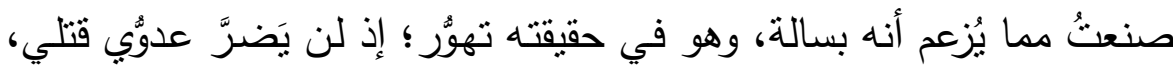

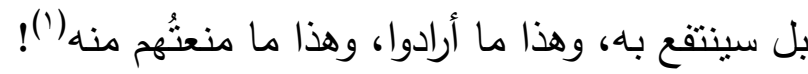

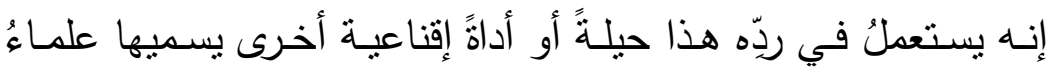
النفس (العقلنة) أو (التبرير) (r)، وهي حيلةٌ دفاعيةٌٌ معروفةٌٌ من أدوات الدفاع عن النفس، يبحث بها صـاحبها عن تسويخ فعلٍ لا يليق بـه أو فعل يحمل صفة الثَّناعة ويدعو إلى الإنكار ، في"يرّر المره بهذه الحيلة سلوكه ومعتقداته

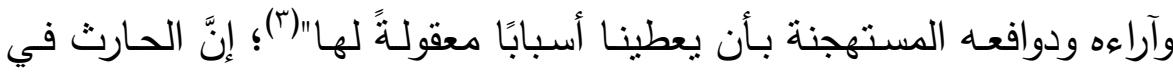
خطابه قد استخدم عقله في موضعين: موضع انفراده في القتال وأنه سيُقتل لا لاءله محالة إن واصل القتال، وموضـع أنـه نجا بنفسه ليعود إلى قتالهم في موقفٍ

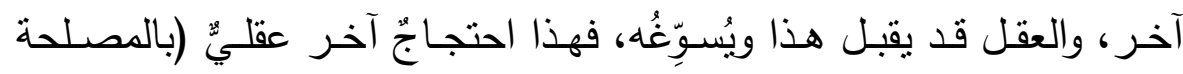
الراجحة).

(1) إن من المستقِّ المتعارف عليه أنَّ الأصل في القتال جَبْهُ العدوِّ وإزاحتُه، فإِذا كان

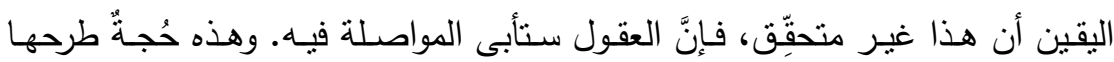

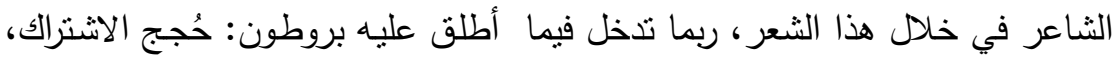

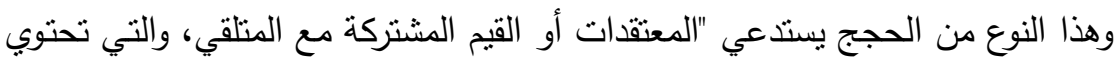

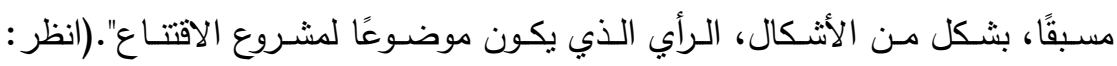

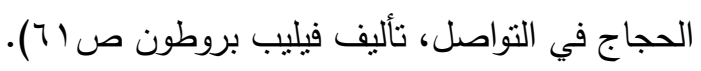

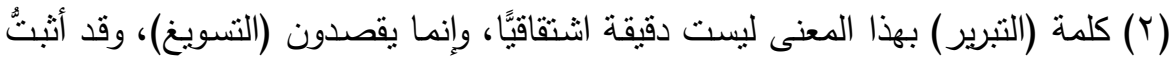

$$
\text { الثائع في علم النفس. }
$$

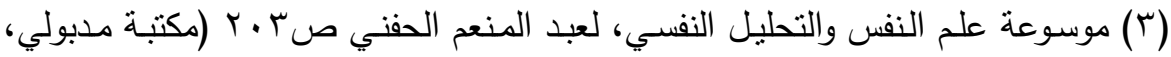

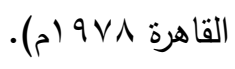




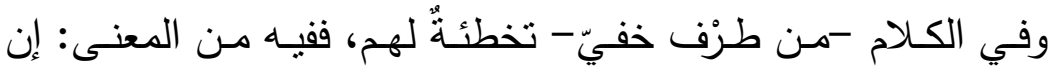

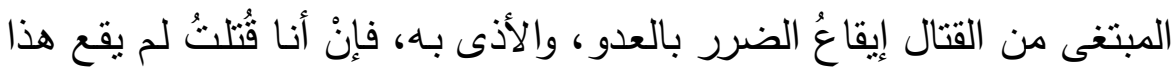

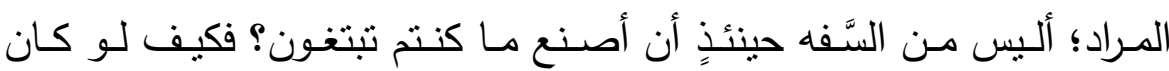
المبتغى من هربي من هذا الموضع الذي قُتل فيه الأحبة أو أوذوا أو أُسروا؛ أن أعود لأنتقم لهم؛ فليس المقصود أني أهرب من أجل الهرب، كلا، بل إني قد غادرثُهم لأعود:

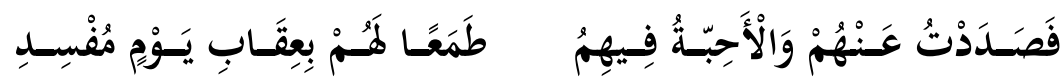

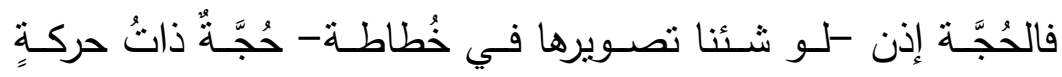

دائريَّة: (تركهم، ليعود)؛ فلا بأس حينئذٍ من هذا الترك؛ لأنه سيعود، فهو ليس

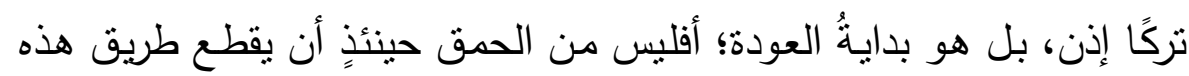
العودة بإيقاعه نفسَه في مهاوي الزَّدى!

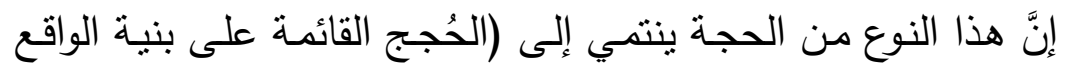

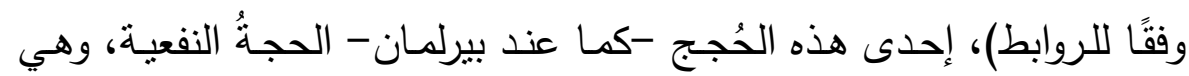
التي تربط قيمة السبب بقيمة نتائجه، كهذا المثال: "هذه السياسـة جيدة؛ لأن

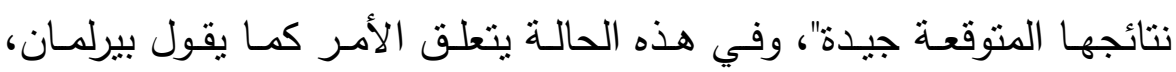

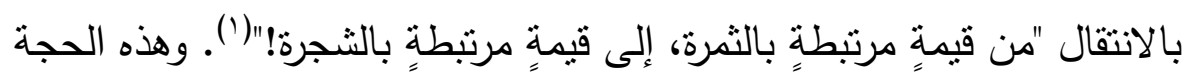

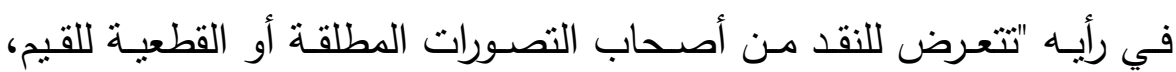
خاصةً الأخلاقية"(؟)، كشناعة الفرار في الذوق العربيّ العامِّ إذ ذاك. لك.

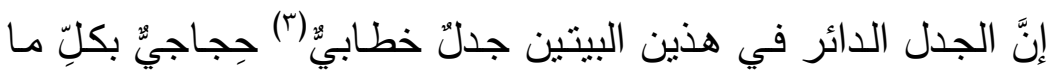

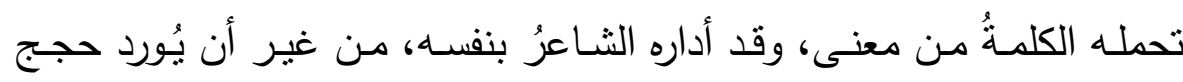

(1) انظر : تاريخ نظريات الحجاج، لبروتون وجوتييه ص •0. (1)

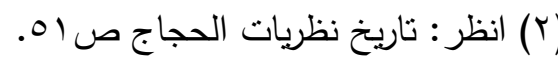

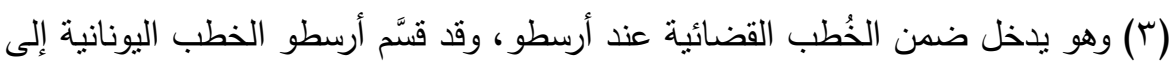

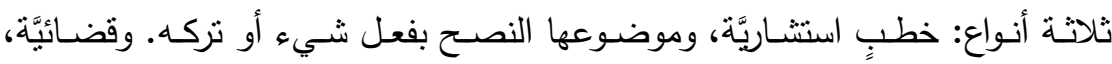

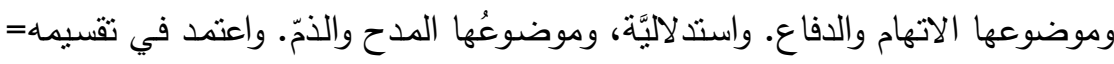


المخالفين، إلا ما استقرَّ في النفس من معرفة سوء تللك الفِعلة. وهو يعتمد على الى وجود (الجمهور) المترقّب كيف سيجيب الثاعر عن خطيئةٍ في ظاهر عُرْف

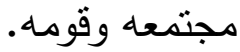

إنَّ الشعر هنا يجنح إلى استعمال الاستعارة في دعم الحُجج العقلية، وللقوم وَلَعْ بمثل هذه الإجراءات الثعرية كالتشبيه والاستعارة والكناية ونحوها،

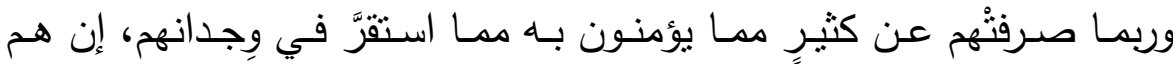

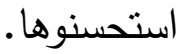

وليس غائبًا عنَّا أن الثـاعرَ قد تباعد كل المباعدة عن أن بستعمل لفظتي (الفِرار) أو (النجاء) التي وصدَه بها حسَّانُ وهو يُعَبِّره ويشتفي منه، في قوله:

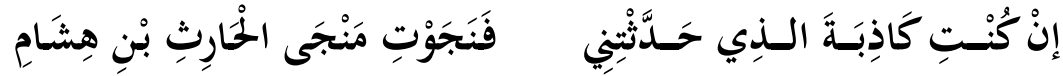

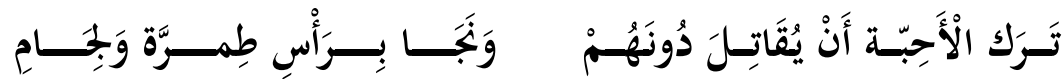

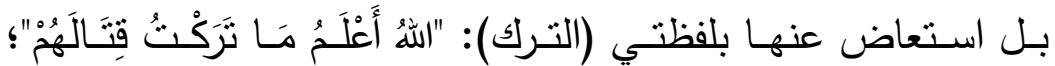

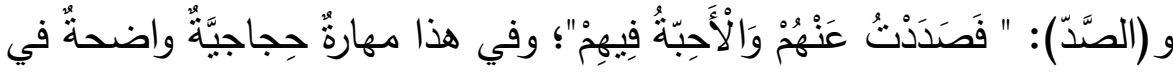

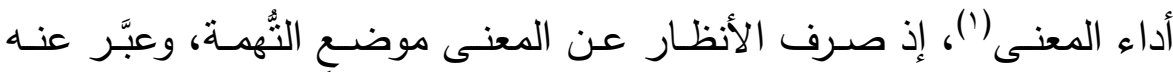

$=$

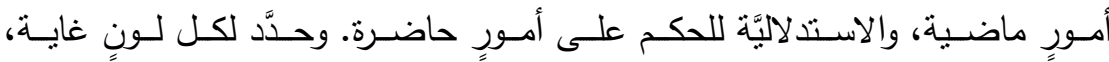

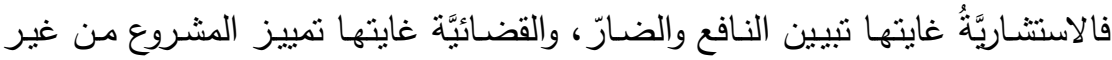
المشروع، والاستـلاليَّة غايتُها بيـان الجميل أو القبيح من الأفعال (انظر : الخطابـة،

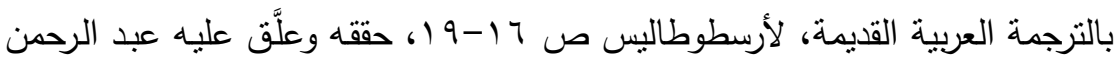

$$
\text { بدوي، دار القلم، بيروت } 9 \text { (9 ام). }
$$

(1) يرى بعضهم في دراسة الثشعر "أن اختيار لفظةٍ دون مرادفها قد يكون على أساس شكليّ، فهو

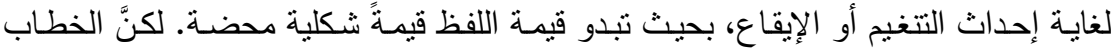

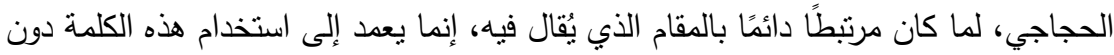

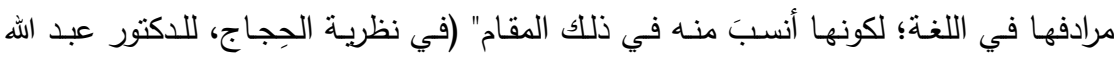

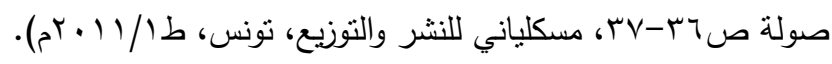


بلفظتين أُخريين: لفظةٍ مخفَّةةٍ من المعنى الأصليّ هي (الترك)، ولفظةٍ بعيدة السبب عنه هي (الصَّدود)، والصدودُ والإعراض يكونـان عن اختيارٍ لا إكراه فيه، أو لا إكراه عليه.

جاء في (العِقْد الفربد): سُئل بعض علماء الثُعر : من أشعر الناس؟ قال الذي يُصوِّر الباطل في صورة الحق، والحقَّ في صورة الباطل، بلُطف

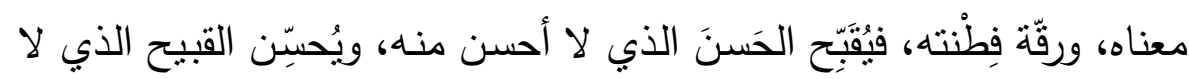
أقبح منـه. ثم قال ابن عبد ربـه: فمن تحسين القبيح قولُ الحارث بن هثـام

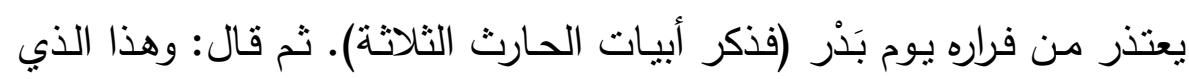

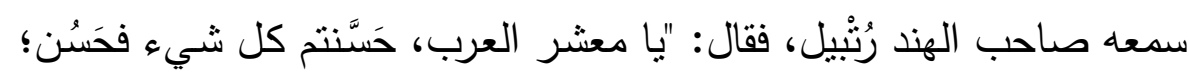

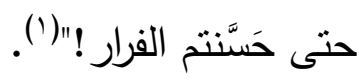

\section{-}

ومما يتصل بسياق فَرَّة الحارث يوم بدرٍ ، وما ولَّدنْهُ من أشنعارٍ أخرى

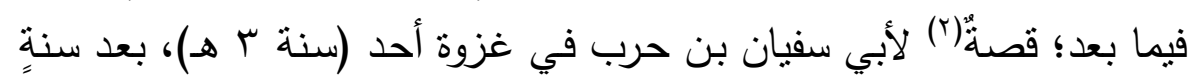

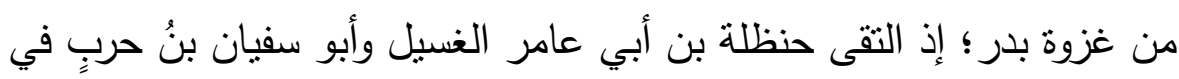

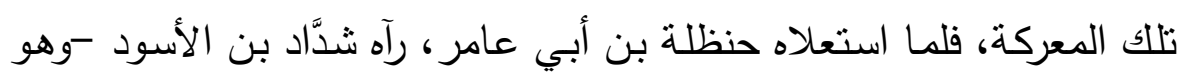

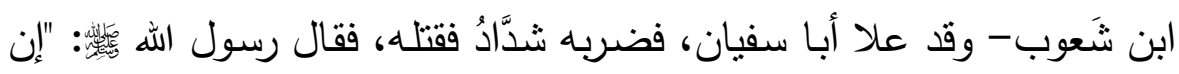

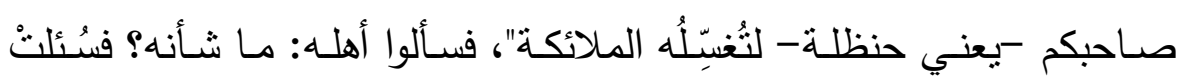
صاحبتُه فقالت: خرج وهو جُنُبُ سمع الهاتفة، قال ابن إسحاق: فقال رسول الله فقال شدَّاد بن الاسود يذكر إنقاذَه لأبي سفيان بن حربٍ وقتلَه حنظلة، مرتجًٍِا:

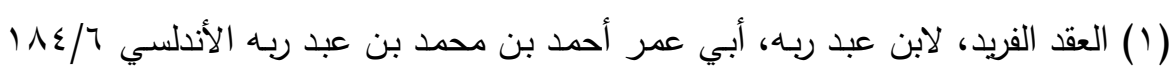

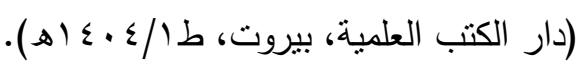

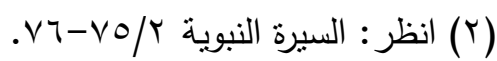




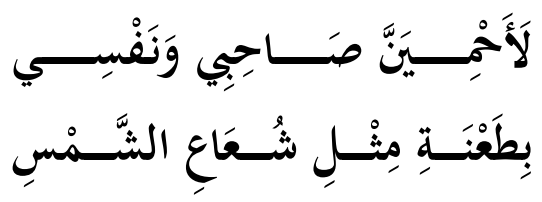

فقال أبو سفيان بن حربٍ وهو يذكر تلك الحادثة، ويعترف بالفضل لابن شَعوبٍ في إنقاذه، ويُعَرِِّ -وهذا هو الثَاهد- بالحارث بن هشام الذبي

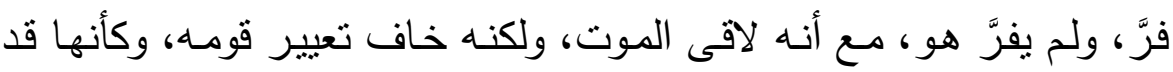

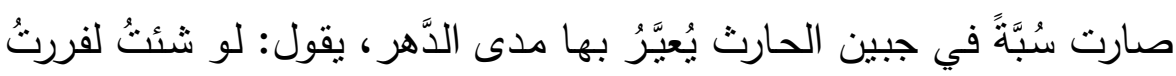

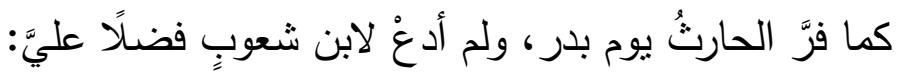

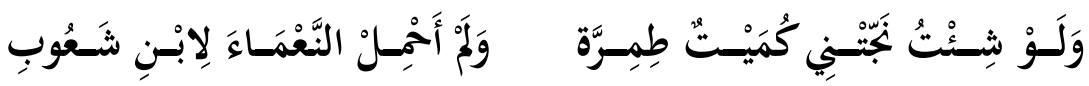

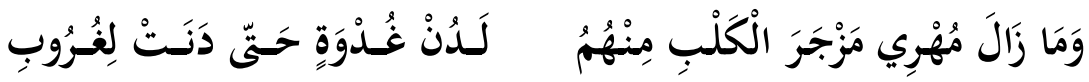

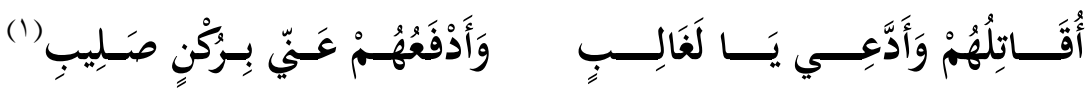
إنـه يذكرُ لفظـة حسـان في وصف فرس الحارث الفارّ : "طمرَّة"، ثم يذكر لفظـة الحسارث نفسـه في وصـف فرسـهـ بـ"الـمُهر"، معرِضِّا بـه، وبهجـاء حسَّان إياه.

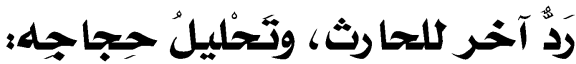

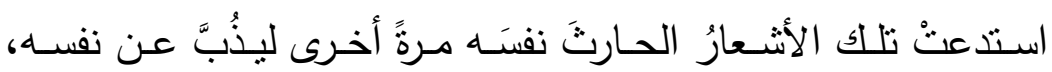

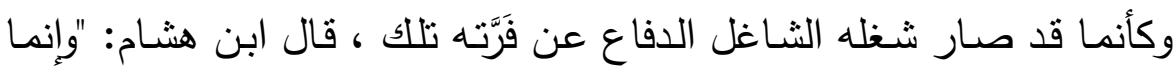

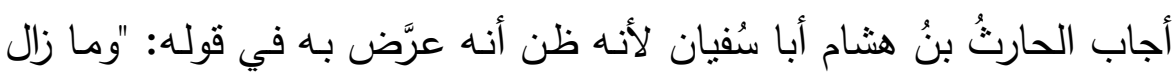

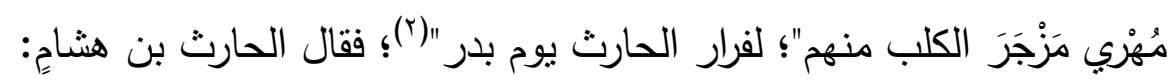

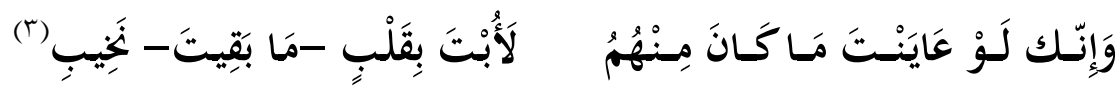

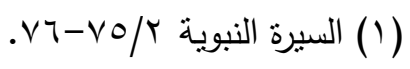

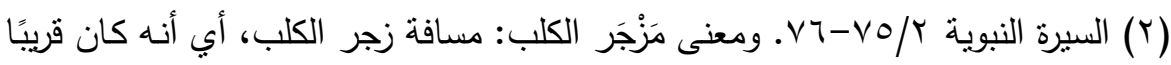
لم يفرّ . (r) النخيب: الجبان الذي لا فؤاد له (لسان العرب: نخب). 


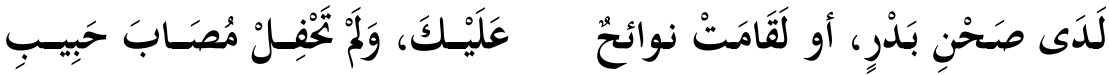

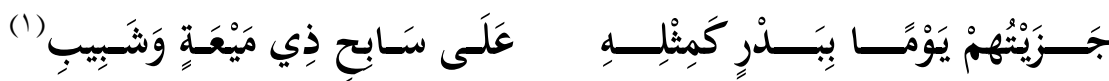

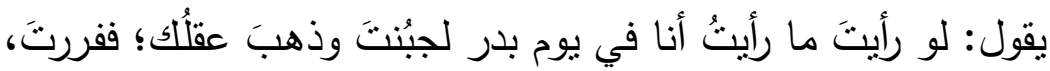
ولم تحفل حينها لموت حبيبٍ قد مـات، وإلّا تفعل فإنك كنت ستُقتل وتتوح عليك النوائح. والفرار محذوفُ مقدَّرُ يقتضيه السياق، وفي البيت تقديمٌ وتأخير يُفهم من الكلام.

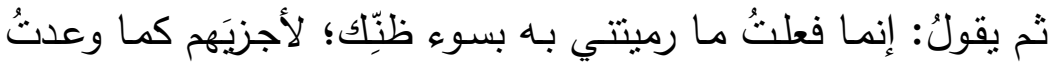

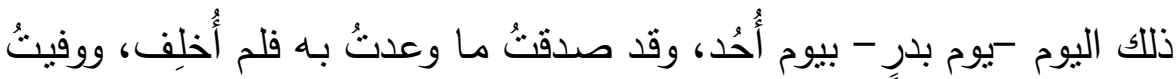
بما قلت. وقد سـاعد الحارث في الردّ مـا كان في يوم أحدٍ من تقدم لجيش الكافرين، مـا جعل حجاجه الأول يبدو كالصـيح، ولذلك أشنار إليهه هنا في

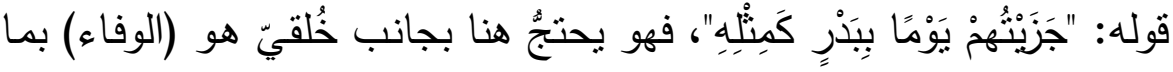
يُنبئ عن صدقه والثقة فيه واستقامة حُجَّنَه. وقد اسـتخدم الحـارث في ردّه على أبسي سـفيان بـن حـرب القضـية

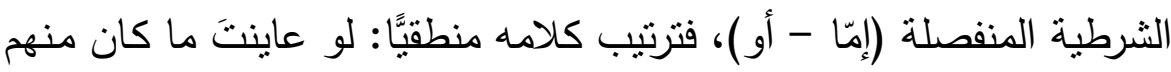

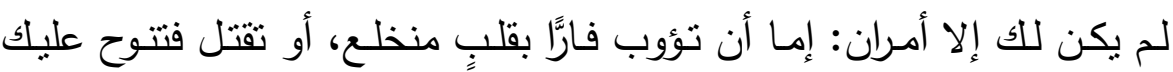

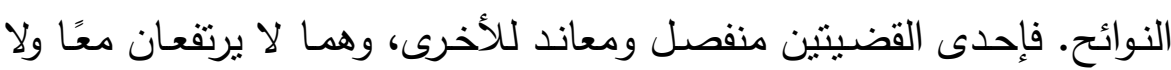

(1) هذه رواية الطبري (انظر : تاريخ الرسل والملوك، لأبي جعفر محمد بن جرير بن يزيد

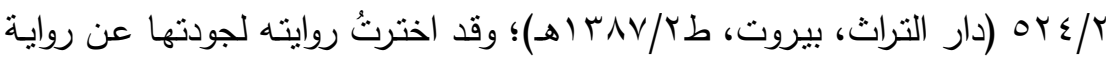

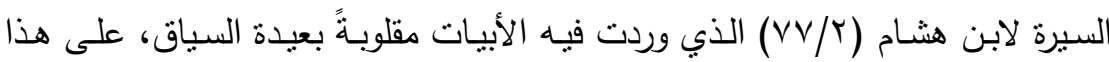
النحو :

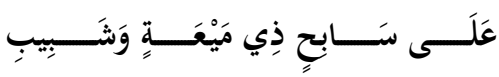

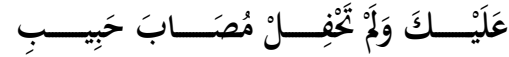

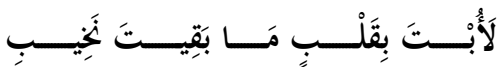

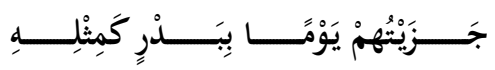

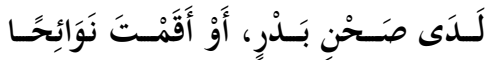

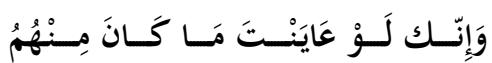




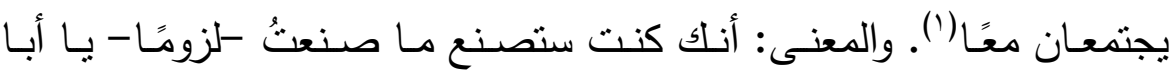
سفيان.

لقد أراد الحارث لا الرد على أبي سفيان بمثنل هذه الحجج، بـل أراد إبلاغ رسالة إلى قومه وإلى كل من يسمع ممن يلومه ليقنعهم بصواب موقفه،

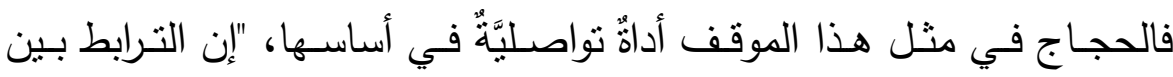
الحجاج والتواصل يتوسع ليشمل ذللك الذي يقوم بين الحجاج والإقناع، فالحُجَّة

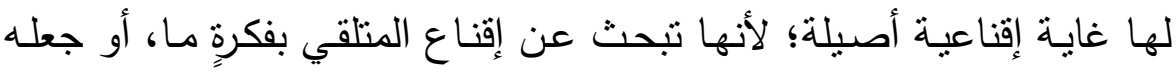

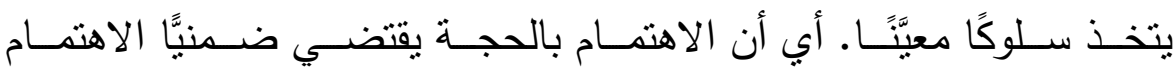

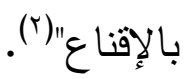
والثاعر هنا أيضًا يستخدم أداةً إقناعيَّة أطلق عليها المناطقةُ (شههادة

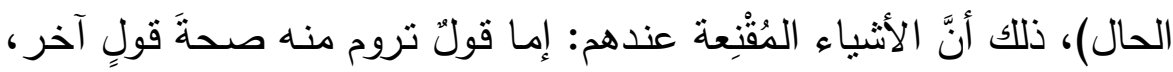
وإمـا شـهادة. والثـهادة: إمـا شـهادة قول، وإمـا شهادة حال، وأمـا شهادة الحسال فمنها ما يُدرك بالعقل، ومنها ما يُدرك بالحسّ، والحال التي تُرك بالحسّ فإما

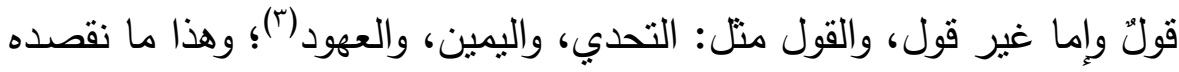
هنا؛ إذ قطع الحارث عهدًا على نفسه، ووفى بـه؛ هذا ما يحتجُّ به في البيت الأخير من شعره؛ وهو خطابُ إقناعه.

وهو هنا يعيد ما ابتدأه من حُجَّة للافاع عن نفسِه، ومن استخدام حيلة

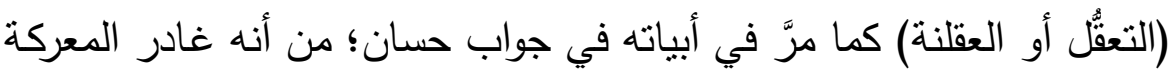
في تلك الساعة لثدَّة ما رأى، لقد رأى الموت، وهو إن لم يفعل لألقى بنفسـه النه (1) انظر : المنطق، لمحمد رضـا المظفر صبr با (دار التعـارف للمطبوعات، بيروت

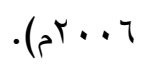

(r) تاريخ نظريات الحجاج، تأليف فيليب بروتون وجيل جوتييه صع ا (ترجمة الدكتور

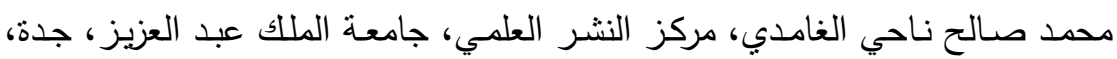

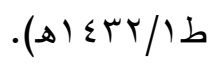

(r) انظر : الخطابة، لأرسطوطاليس (بنائيص وشرح ابن سينا) صو 9. 
في التهلكة، فلم تُمْكنه العودة إلى أعدائه للانتقام منهم، كما قد صنع الآن،

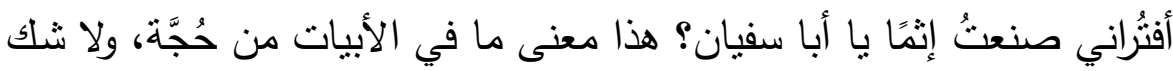

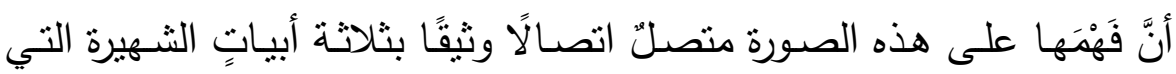

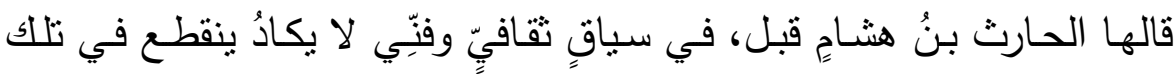
الحرب الدائرة بين الفريقين في تلاك الأيام الثديدة من صدر الإسلام.

-

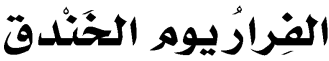

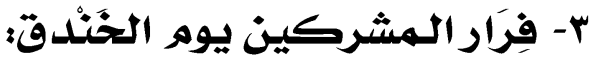

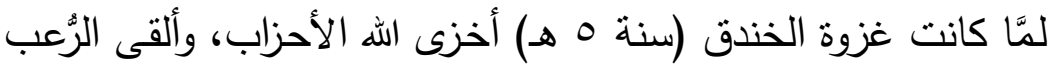

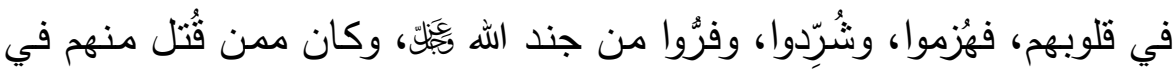
تلك الغزوة فارس قريشٍ عمرو بن وُدٍٍ الذي دعا للنزال في رهطٍ معه، فنازله

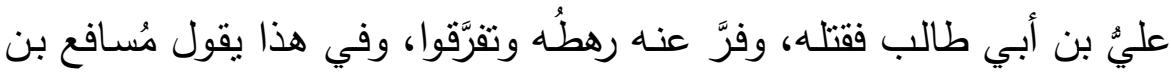

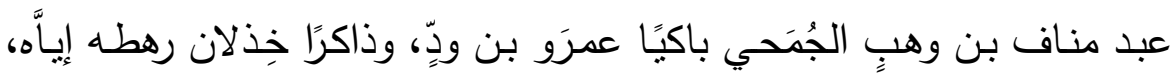
وفرارهم عنه:

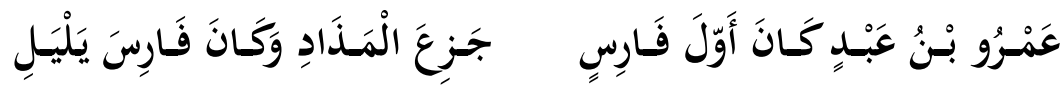

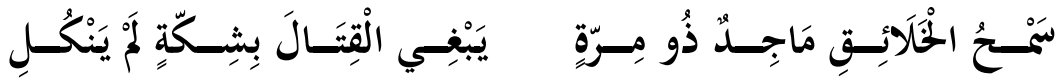

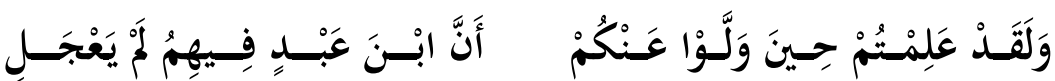

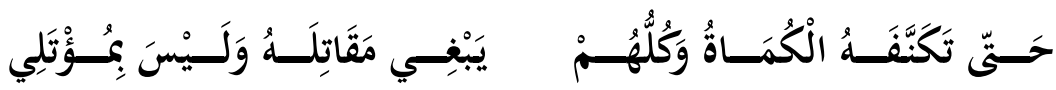
ردُ هُبَيْرة بن وَهنبِ، وتَحْليلُ حِجاجهـ

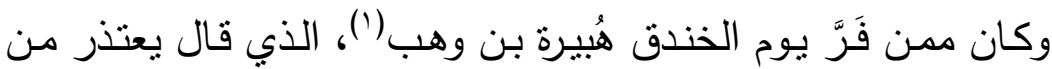

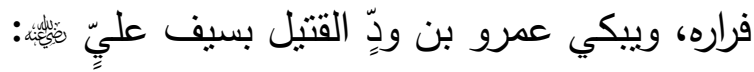

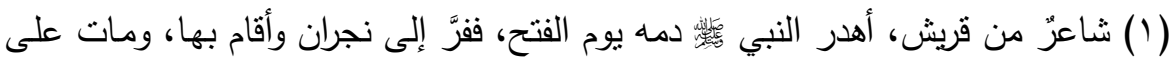

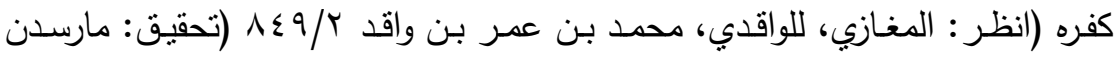

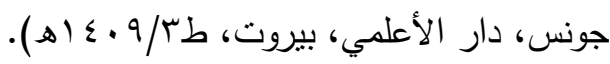




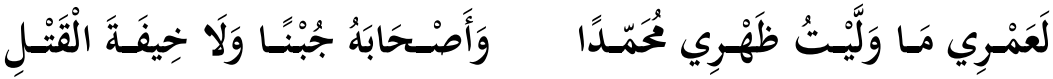

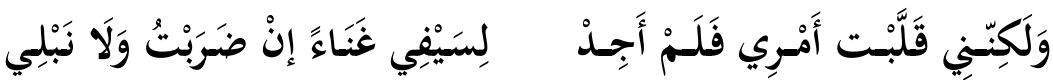

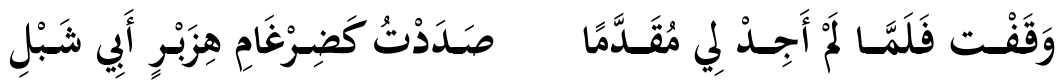

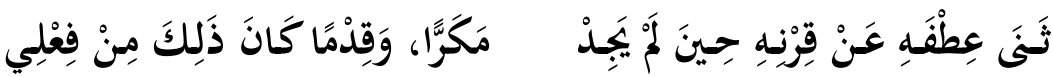
إن الحُجَّة هنا زعمُ (التعقَّل) لا الطَّبش والسَّفَه، يقول: ما فررتُ جُبنًا

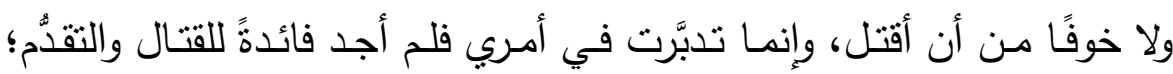

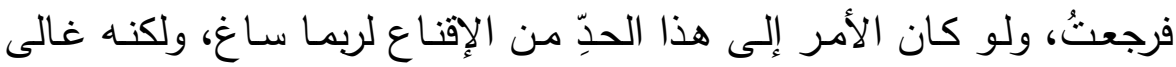
ودخل في حالة من حالات (الإنكار) (') لأن يكون قد جبُن، فقال: حين تدبَّرت الأن

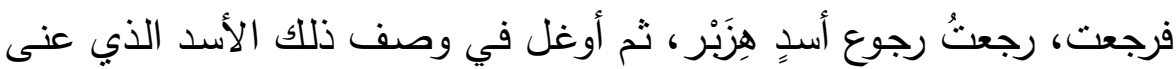

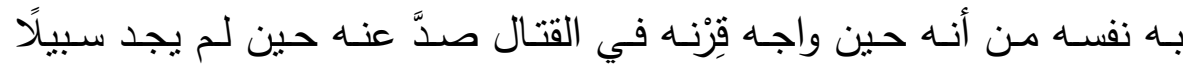

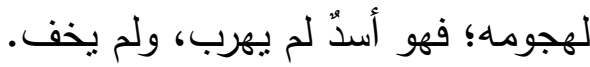

وهذا الإيغال في مدح النفس والتفاخر بها في موضع التهمة والتشنيع نوعٌ من (التعويض) النفسي، يملأ به المنَّهم بالعيب ما نقص من أخلاقه أمام

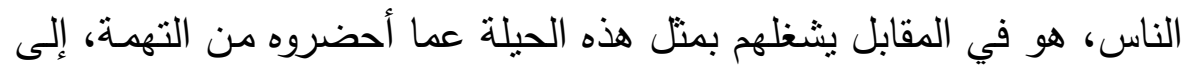

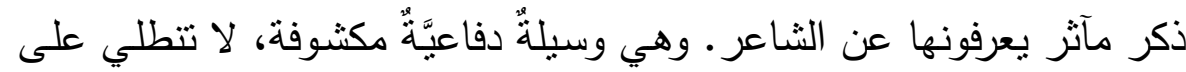
كثيرٍ من الناس.

وقد نُقل في (عيون الأثر) عن الأصسمي أنسه كان يفضِّل اعتذار

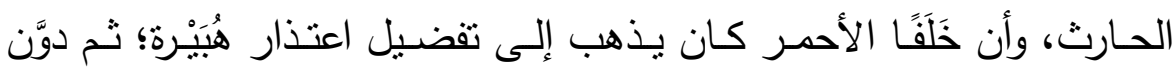
صاحب الكتاب رجحان قول خلف، وأسباب تقديم شعر هبيرة، فقال: إنها وإن هان "تقاربـا لفظًا ومعنَّى، فليس ببعيدٍ من أن يكون الثاني أجودَ من الأول؛ لأنـه

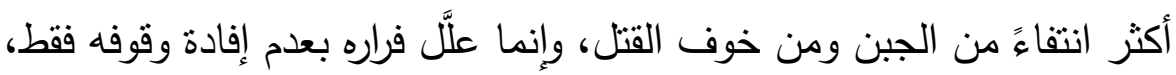
وذلك في الأول جزءُ عِلَّته، والجزء الآخر قوله: أقتل، وقوله: رموا مهري بأشقر

(1)The Ego and The Mechanisms of Defence, Anna Freud, Karnak books, Exeter, 1993. P. 70. 
مزبد، يعني الدم. ويحتمل أن يكون ذلك مقيَّدًا بكون مشهده لا يضرٌّ عدوه، ومع ذللك فالثاني أسلم من ذللك معنى وأصرح لفظا ومعنى "( ').

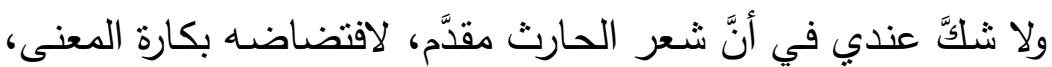

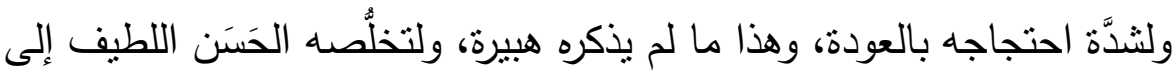

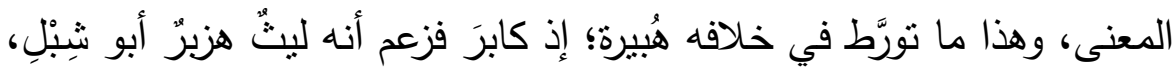

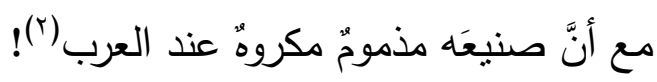
وحتى لفظة (الصدود) تشي بأخذه المعنى من الحارث، ثم تباطر فيه -وهذا لم يصنعه الحارث- بأنه صدَّ كالضـرغام الهِنَبر ، ولم يذكر مـا ذكره الحارث من أنه فرَّ ليعود؛ فالحركة الدائرية لم تكتمل هنا. وبين شعر الحارث في بدر، وشعر هُبيرة في الخندق ثناث سنواتٍ فحسب، وكلاهما رجلّ قرشيّ، فلا شكَّ -عند تدقيق النظر - في استنفاد هُبيرة أبياتَّ الحارث بن هشام.

(1) عيون الأثر في المغازي والبِّيَر، لابن سيد الناس، محمد بن محمد بن محمد بن أحمد

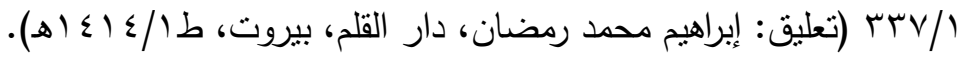

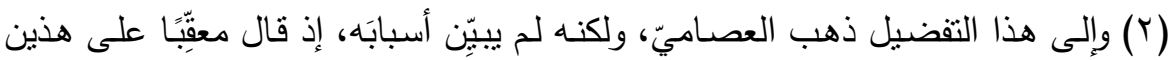

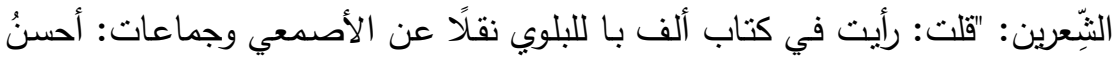
ما قيل في الاعتذار عن الفرار، قول الحارث بن هشام هذه الثلاثة الأبيات. وخالفه من

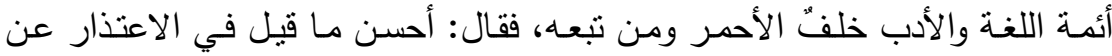

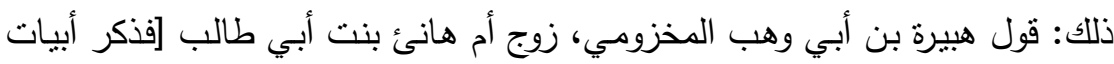

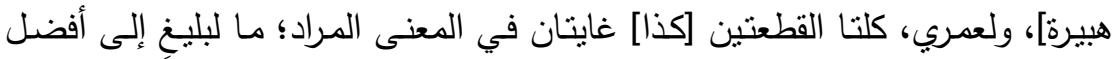

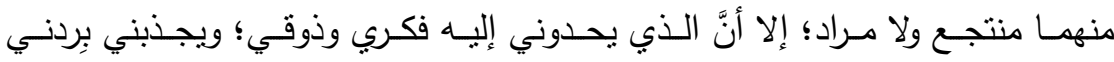

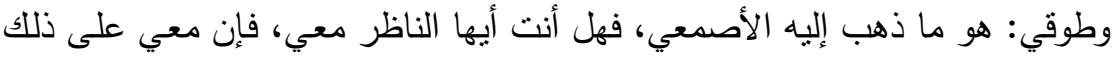
شهودًا معدَّله؛ تثبت لعبد الملك الفخر لـه". (سمط النجوم العوالي في أنباء الأوائل والتوالي، للعصامي، عبد الملك بن حسين بن عبد الملك المكي / 1 • ا، تحقيق عادل

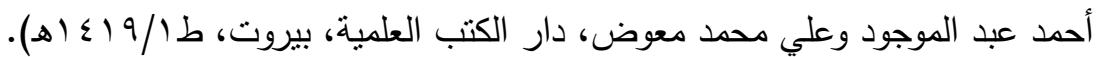




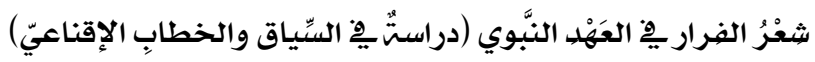
حوليتة كليتة اللغت العربيت بإيتاي البارود (العدد الثالث والثلاثون)

وهذا جدول يُظهرنا على هذه الفروق الثِِّعرين:

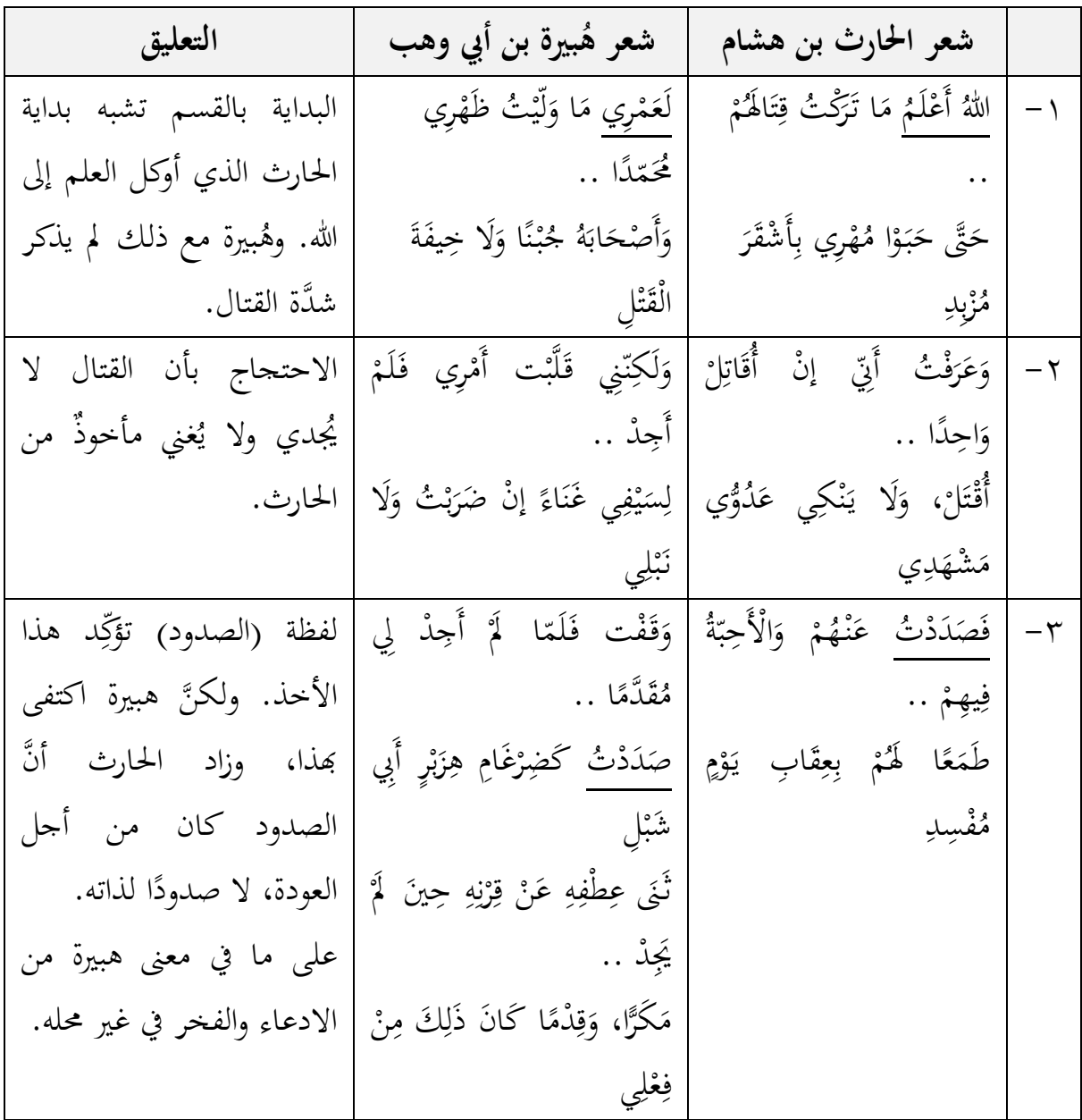

ثم يخرج هُبيرة من فخره هذا إلى رثاء عمرو بن ودّ في محاولة لإبعاد

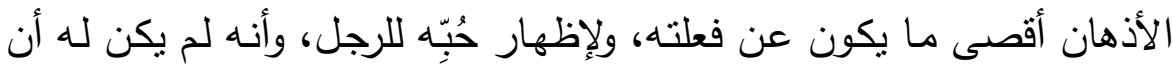
يفرَّ عنه:

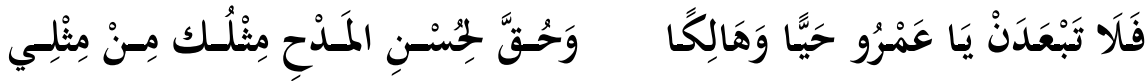

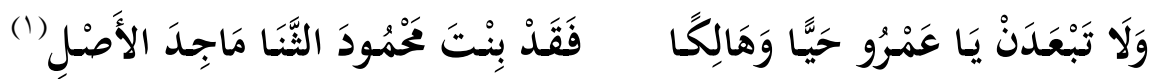
إلى آخر تلك القصيدة. 
ولم يزل هُبيرة بن أبي وهبٍ يبكي عَمْرو بن وُدِّ في قصيدِه، ويذكرُ

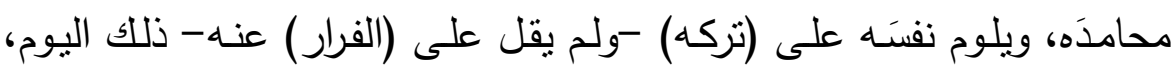

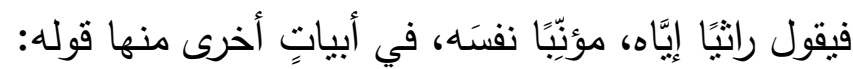

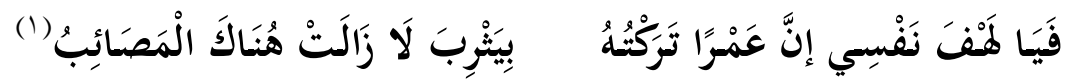

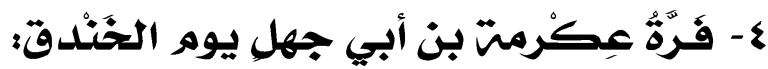

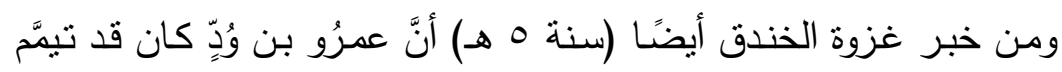

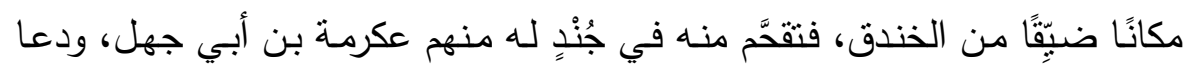

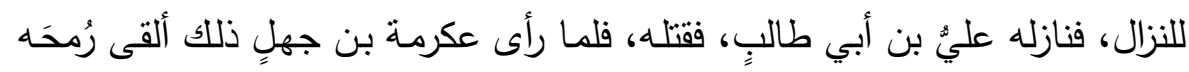

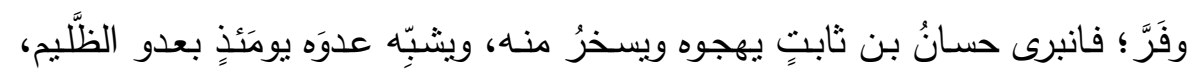

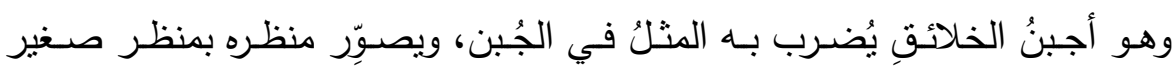

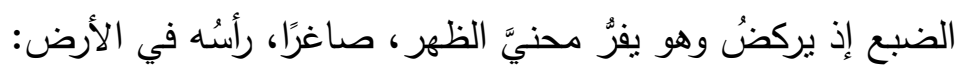

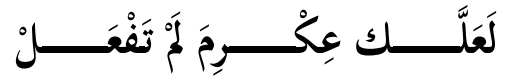

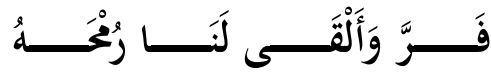

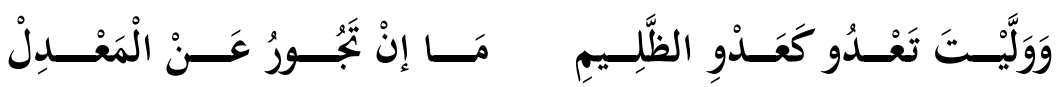

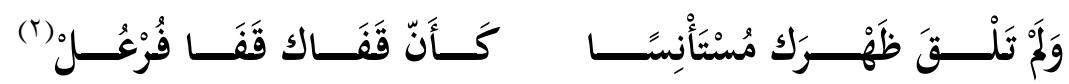
ولم يبلغنا -فيما نعلم - ردٌّ من عكرمة على هذا الشعر .

\section{-}

ه- فِرارُ يُيهود خَيْبر:

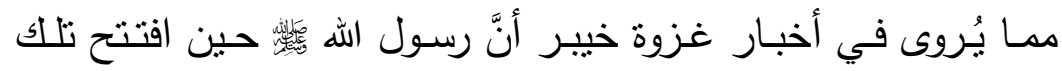

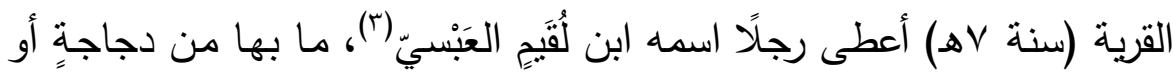
داجنٍ، فأنثأ ابنُ لُقيم يقول في تلك الغزوة:

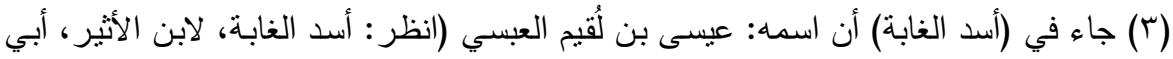

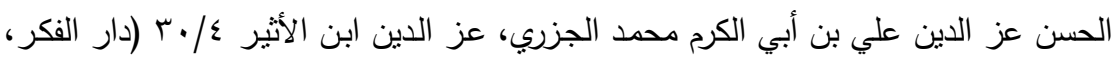




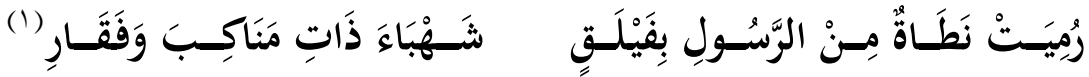

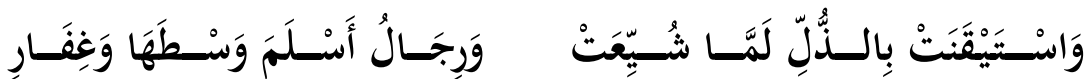

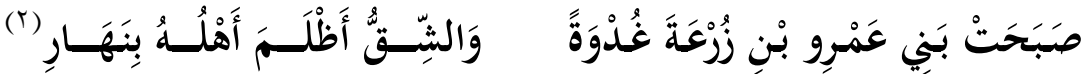

ثم راح يحكي لنا مشاهد مما رآها في ذلك اليوم، يصور بها حال فرار

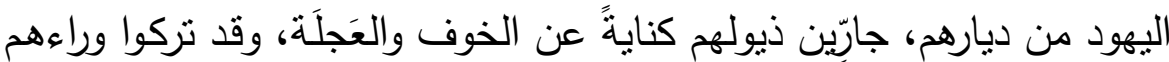

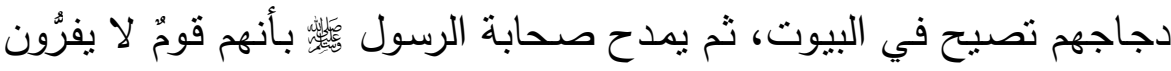
كما فرَّت يهودُ خيبر : تهن

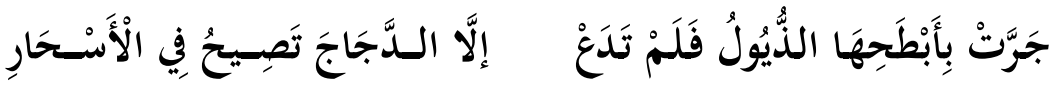

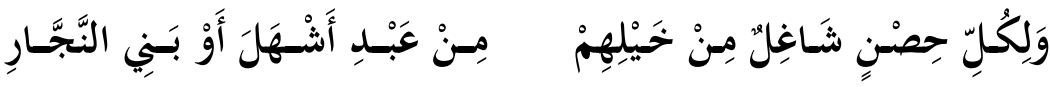

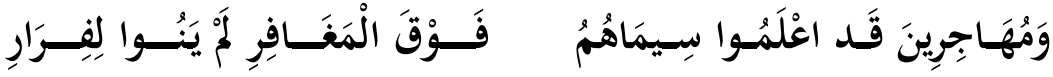

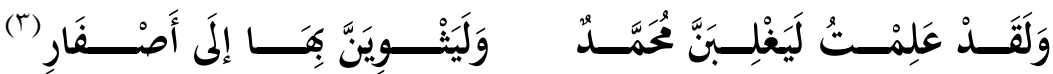

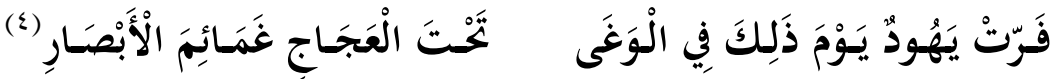
وقد ذهب ابنُ هشام في تفسير البيت الأخير في الثعر مذهبًا بعيدًا

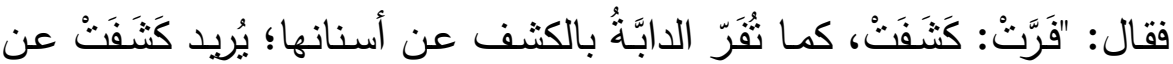
جفون العيون غمائحَ الأبصار ، يريد الأنصار "(ه). هذا تفسيره، غير أنَّ السُّهيلي

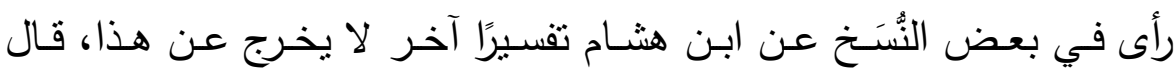

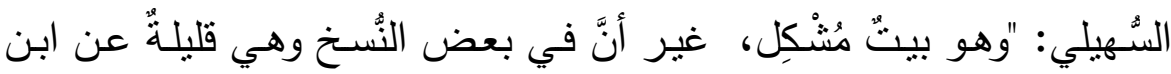

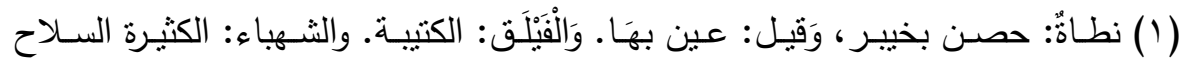

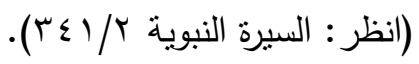

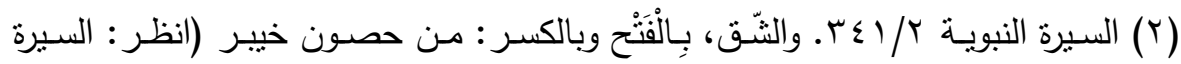

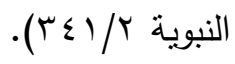

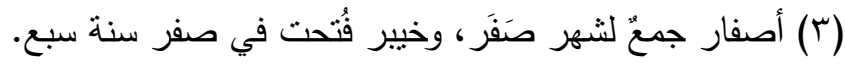

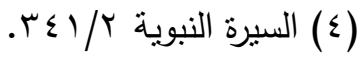

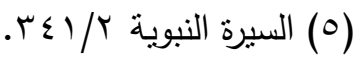




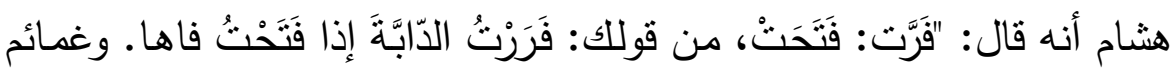

الأبصار هي مفعول فَرَّت، وهي جفون أعينهم، هذا قول" (1).

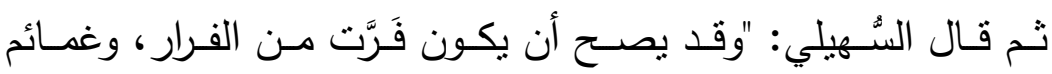
الأبصسار من صفة العجاج وهو الغبار، ونصبُه على الحال من العجاج وإن كان لفظُه لفظً المعرفة عند من لبس بشاذٍّ في النحو ولا ماهرٍ في العربية، وأما عند أهل التحقيق فهو نكرةٌ لأنه لم يُرد الغمائم، وإنما أراد منل الغمائم...."(r). ولعل ما ذهب إليه السُّهيلي أقوى؛ وذلك لذكر الثـاعر الفرار قبلُ في

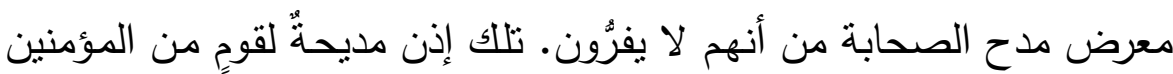
معروفين بالثجاعة والإقدام والثبات، هم المهاجرون، وقد قال فيهم من قبل

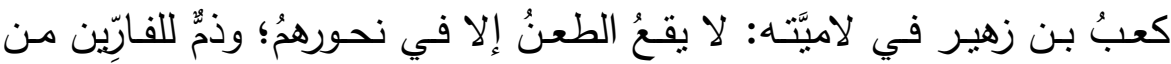

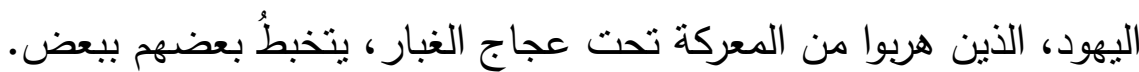

\section{-}

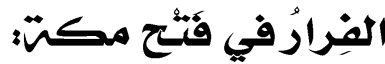

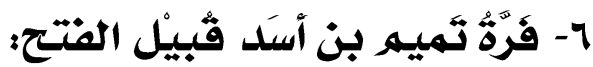

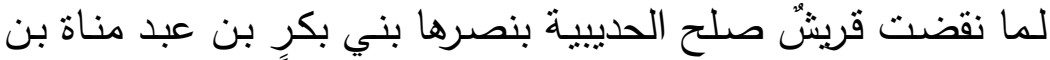

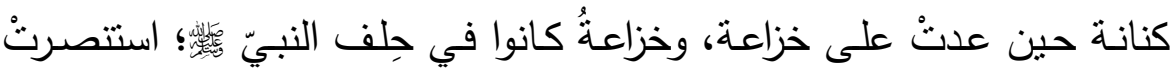

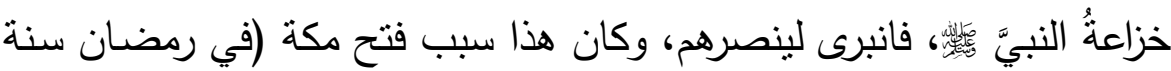
^ هـ). وكان هذا النقض قُبيل الفتح بقليل.

وكان من حديث ذللك أنَّ أحد المقتولين من خزاعة كان اسمه مُنَبِّهًا،

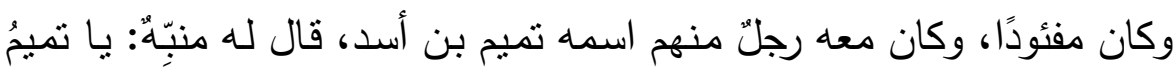

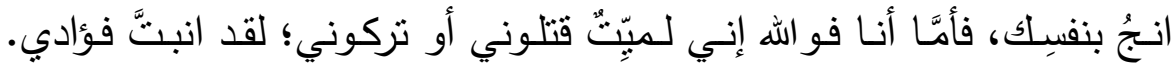

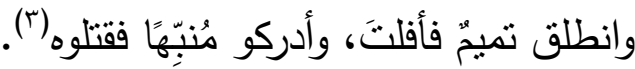

$$
\begin{aligned}
& \text { (1) الروض الأنف، للسهيلي 14/71/. }
\end{aligned}
$$

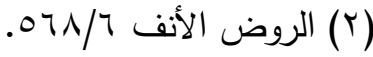

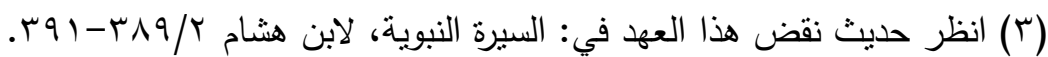




\section{دفاعُ تمييه بن أسَد ، وتحليلُ حِجَاجه:}

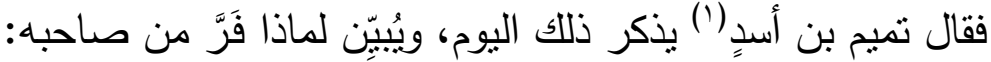

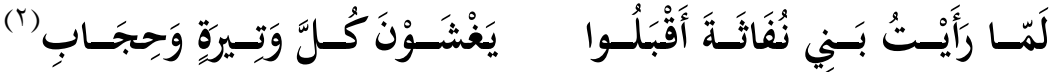

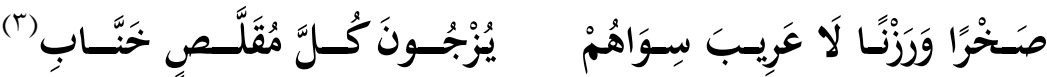

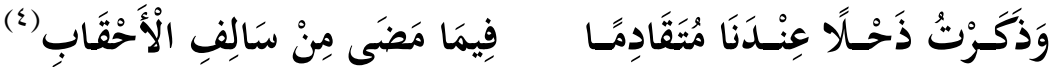

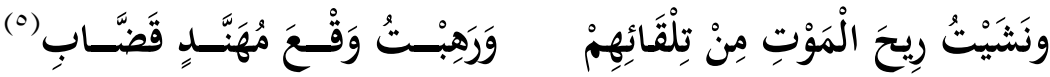

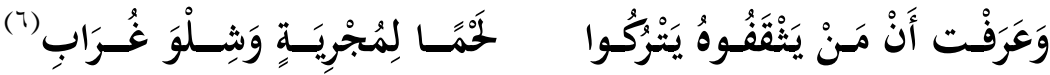

إنها ثمة تهويل للصورة في الأبيات السابقة لكسب عاطفة المخالفين، وتهيئتهم للنتيجة الآتية في البيت التالي:

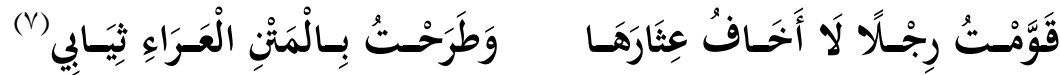

هنا اعترافُ بالهرب، من غير مواربةٍ أو تملُّص أو تقلسف. إنه يقول: هربتُ لئلا أموت، فقد شمت رائحة الموت، وخفت وقع المهند الذي سيُهلكني. وهذا تصريح نفعيٌٌ بحت بحب الحياة وتجاهل المحامد المعنوية من الإقدام

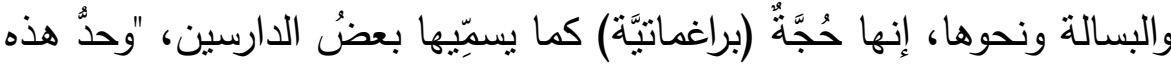
الحجة أنَّها الحجة التي يحصل بها تقويٌُ عمل ما أو حدثٍ ما باعتبار نتائجه الإيجابيـة أو السلبية... إن مدار هذه الحجة كما قلنـا على تثمين حدث مـا

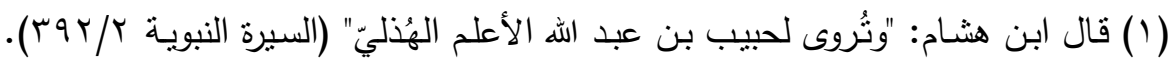

$$
\begin{aligned}
& \text { وشرح غريب الأبيات الذي سيأتي بعد من المصدر نفسه. }
\end{aligned}
$$

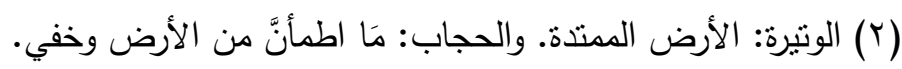

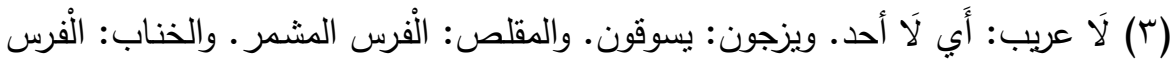

$$
\text { الوَأبسع المنخرين. }
$$

(ع) الذحل: طلب الثار . والأحقاب: السنون.

(0) نشى: شم. والمهند القضاب: السَّيْْ الْقَاطِع.

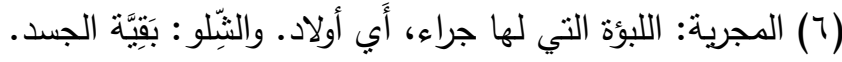

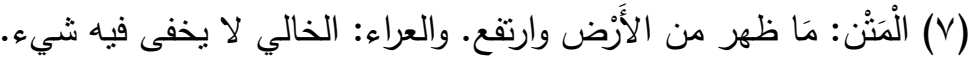


بذكر نتائجه، فعلى هذا لا يكون المقصود من هذه الحجة مجرد التثمين، بل

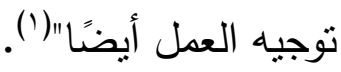

إنه ييني خطابه إذن على مقدمةٍ مطولة يذكر فيها الأسباب، ثم يقرنها بالنتيجة التي جعلها صالحةً يمليها العقل السليم. ثم إنه وضع في حجاجه لبنةً ثالثة، بعد لبنتَيْ الأسباب والنتيجة، لبنة التخويف بالافتراض، إذ يقول للائمته: ثم إنك لو شهدت لدخلك الرعب حتى بلت من الخوف؛ والمعنى أن (نجائي) هو عين العقل والتصرُّف السليم هع أن القوم يعلمون أن لا أترك صاحبي عن طِيب نفس، إنه نداء العقل (البراغماتي)

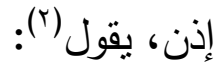

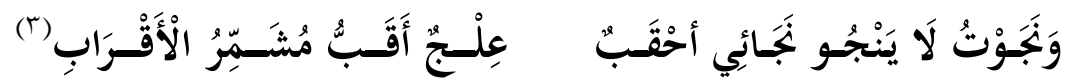

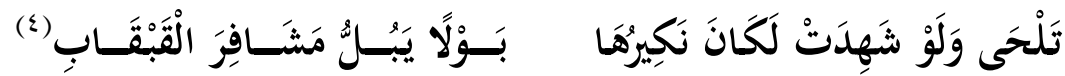

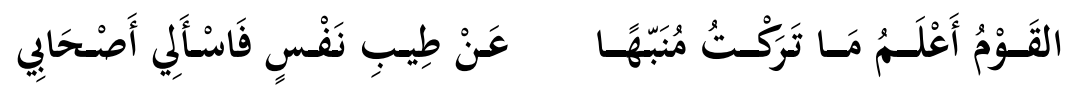
إن في البيت الأول من هذه القطعة تجاهلًا للإثتم، وطمرًا له بالإيغال في الفخر؛ وذلك ليَّا للأعناق عما هو فيه من الخطأ، وهذه طريقة تتخذ مبدأ: (التجاهل والحيدة عن المسألة)(0)، فمن دفاعٍ عن النفس يعمد الثـاعر عمدًا إلى ذكر محامدها، متغـافلًا عما يُرمسى بـه من النقائص؛ وكلُّ هذا للتعميـة والإلهاء.

$$
\begin{aligned}
& \text { (1) في نظرية الحِجاج، للاكتور عبد الله صولة ص •0. }
\end{aligned}
$$

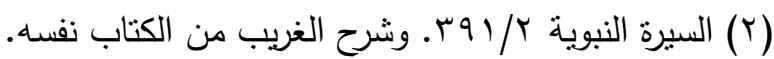

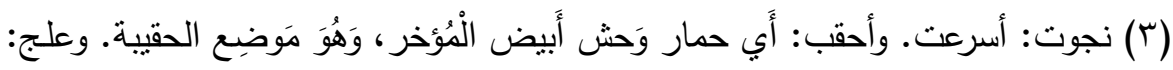

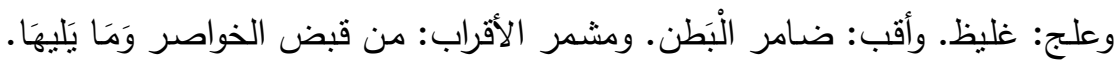

$$
\text { ويروى: "مقلص الأقراب"، وَهُهَ بِمَعْنَاهُ. }
$$

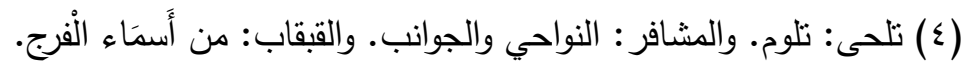

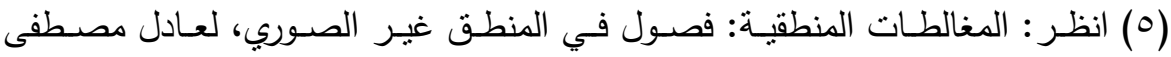

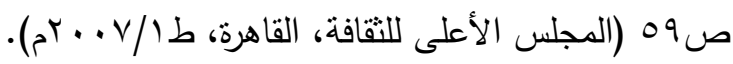


ثم إن الثاعر يتجاهل ذكر لفظ (الفرار)، ويذكر لفظة (الترك)؛ تتائيًا بنفسه وحاله عن هذه النقيصة، فهو نوعٌ من الدفاع النفسي الذي يصوره لغويَّا باختيار ألفاظه.

\section{$\hat{n} \hat{n}$}

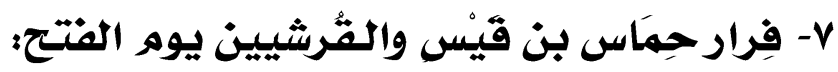

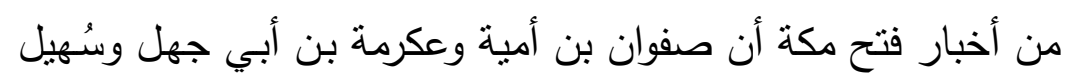

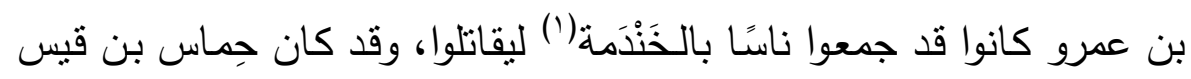

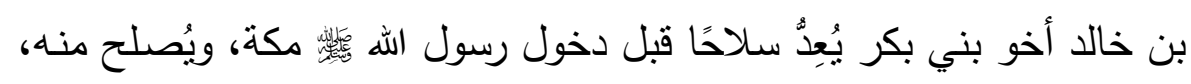

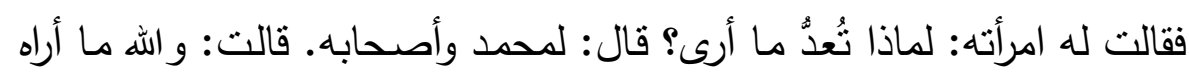

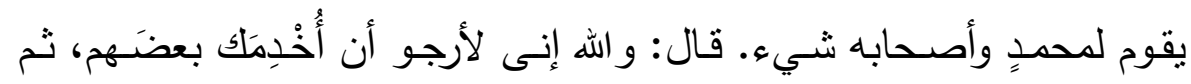
قال:

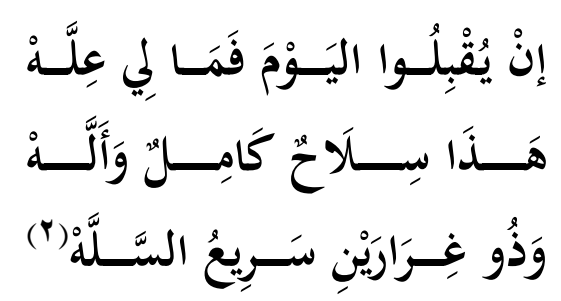

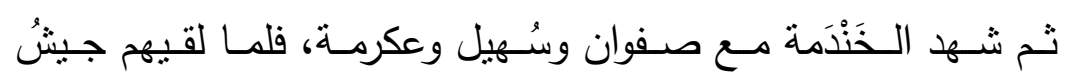
المسلمين انهزموا، فخرج حِماسٌ منهزمًا فـارًا حتى دخل بيتَّه، ثم قال لامرأتها: أغلقي عليَّ بابي. قالت: فأين ما كنت ثقول؟؛

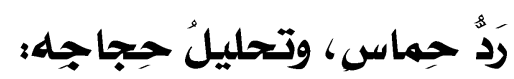
فقال حِماسُ بن قيسٍ يردُّ على امرأتهاهُ ويُحاجج عن نفسه:

(1) الخَنْدمة: جبل معروف عند مكة، كانت بـه وقعـة يوم فتح مكة، ومنـه يوم الخَنْدَدَة

$$
\text { (انظر : لسان العرب: خندم). }
$$

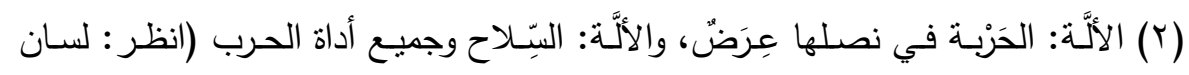

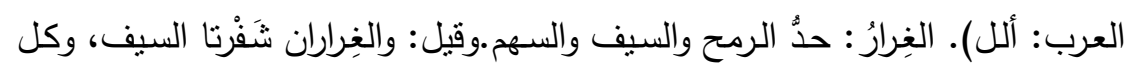

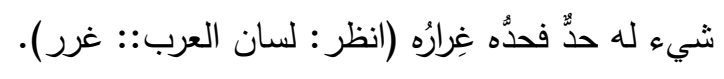



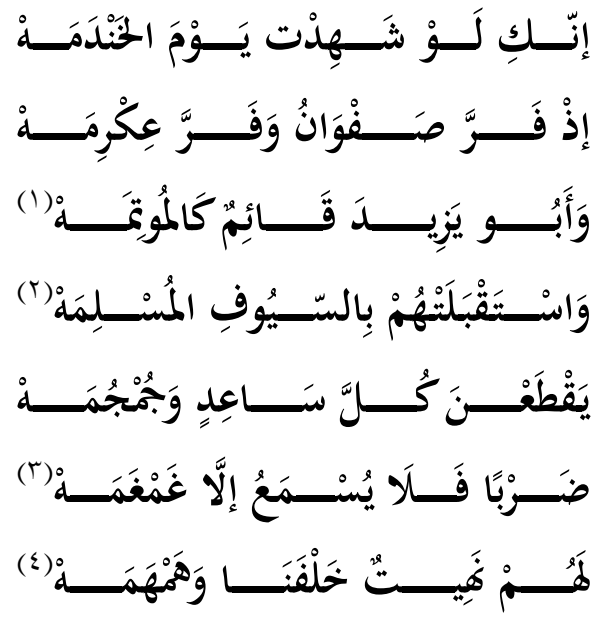

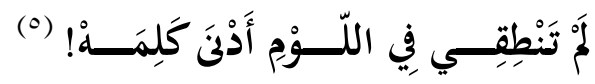

(1) أبو يزيد هو سُهيل بن عمرو المذكور في الخبر، من سادة قريش، أسلم عام الفتح

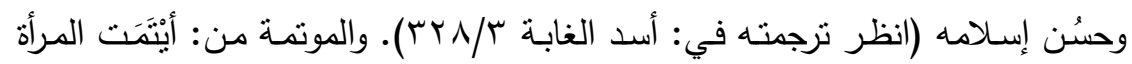

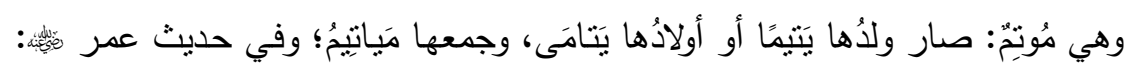

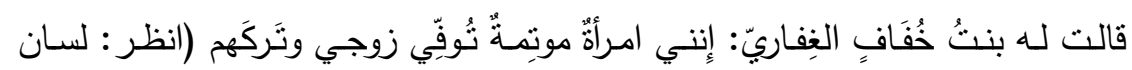

$$
\text { (Y) العرب: اليتم) المسلمون. }
$$

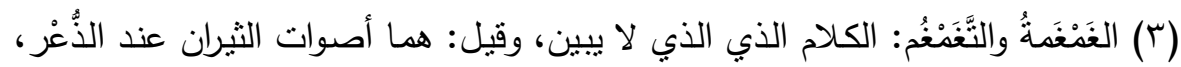

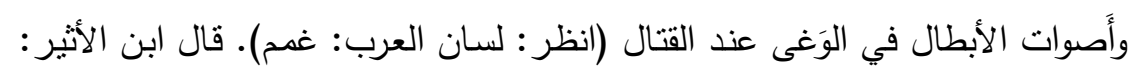

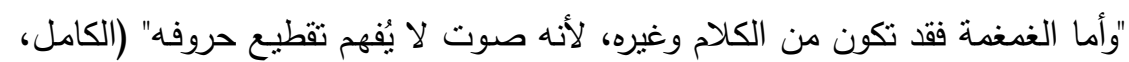

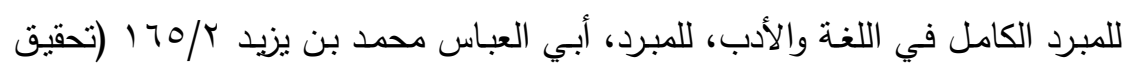

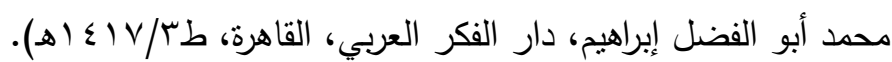

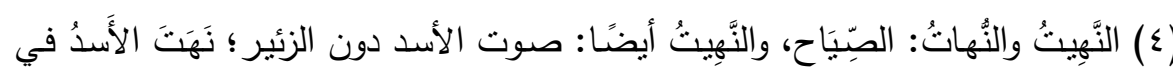

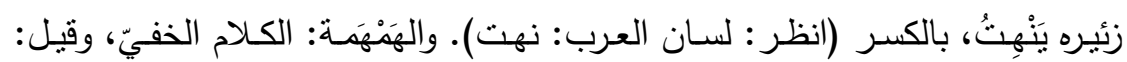

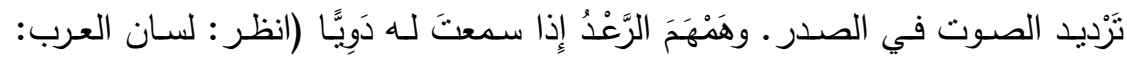

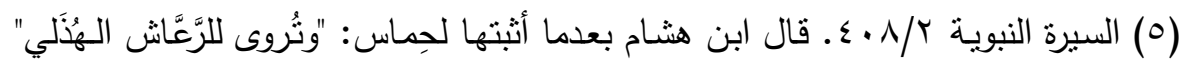

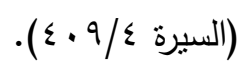




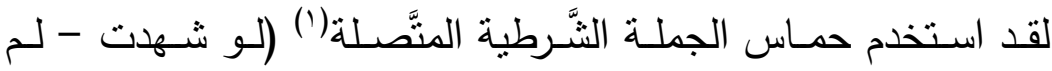
تتطقي)، وباعد بين جُزأيها -وهي جملة في طبيعتها الاتصال - ليشدَّ السامع فيسمع رغمًا عنه تهويله للموقف.

إن الثـاعر يينـي خطابـهـ الإقنـاعي على مقدِّمـة طويلـة يُهوِّل فيهـا

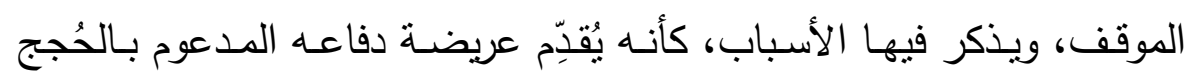
والقرائن؛ لينتهي إلى نتيجة مؤدَّاها: وجوب الاقتتاع بما صنع، وعدم الإنكار

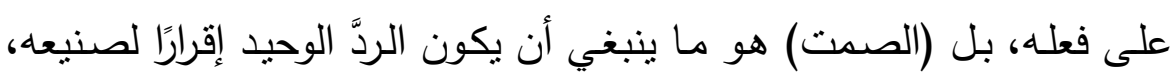
وامتثالًا لكل ما ذَكر.

وقد جـاء في حيـل دفاعـه احتجاجـه بفـرار كبـار القوم ورؤســائهم،

كصفوان وعكرمـة، وقد تعمَّد أن يذكر لفظة (الفرار) مسندًا إليهمـا في هذا الموضع لسببين: أن ينسب الفرار إلى غيره، وأنهح كانوا القدوة الذين تبعهم مَنْ

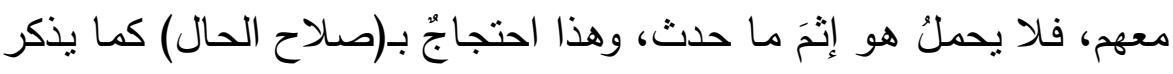
أرسطو (r)؛ إذ كيف نخالف عن أمر قادتتا الكبار؟ والسبب الثاني في ذكره لفظ (الفرار) منسوبًا إلى غيره: نفيُه عن نفسه هو ، فكأنَّ ما تدَّعون من حَدَث الفرار صنَعَه هؤلاء أولًا ولم أبتدئه أنا.

وفي دفاعه جانبٌ عاطفيٌّ تأثنيريّ، فهو يُهوِّل مشهـد القتال تهويلًا عظيمًا

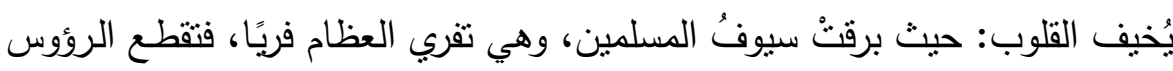

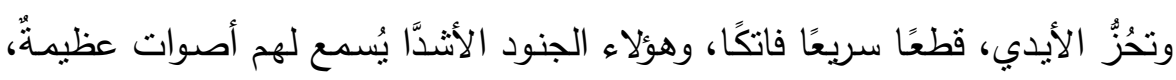

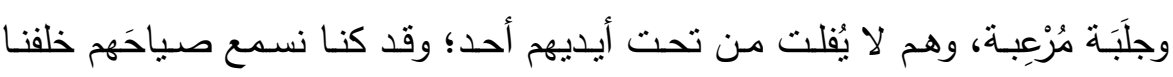

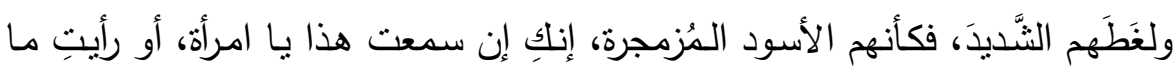
قد رأيتُ، "لم تتطقي في اللوحِ أدنى كلمة".

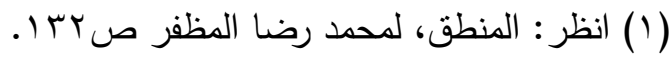

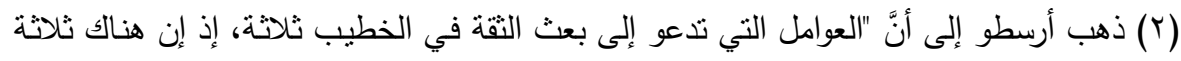

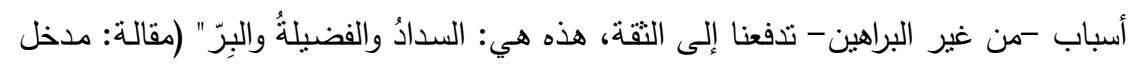

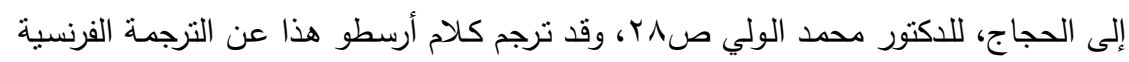

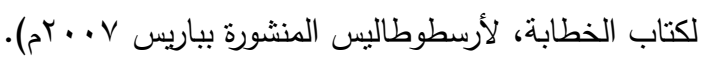


إنـه يُنتير شفقة المخاطَبين -لا امرأته وحدها- بهذا المشهـد المَهُول، شفقتهم عليه، وهذا ليس فيه احتجاجُ كلامي، بل هو حُجَّةٌ عاطفية لا برهانيَّة، إنها (بلاغة مشاعر)، أكبر منها (بلاغة استدلال) (').

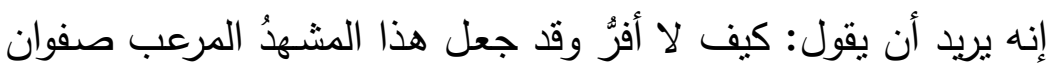
بن أمية وعكرمة بن أبي جهل، وهما من سادتتا؛ يفرَّان، وجعل أبا يزيد سُهيل

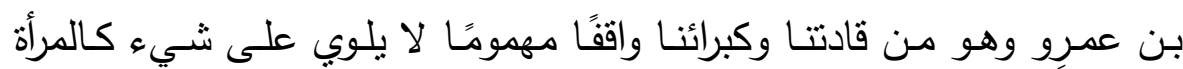
الموتمة، وهي ذات العيال التي مات زوجها عنها. إنَّ هذه الأبيات تدخل ضمن ما يُعرف في الأدب العربي بـ(الـنْنصفات)

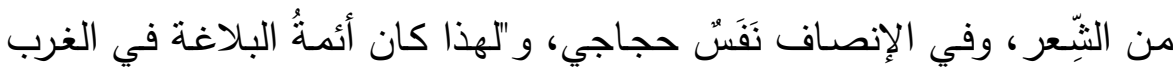
ينصحون الخطيب... بأن يمتدح خصال الخصم الخطابيَّة، وأن يُخفي أو يُهوِّن من خصاله هو في ميدان الخطابة، وذلك من أجل ألَّ تحدث قطيعةٌ بين الشكل

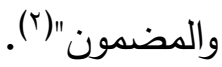

إنَّ ههنا نوعين من الحُجة عند المنظِّربن: حجة السلطة، وحجة التأطير.

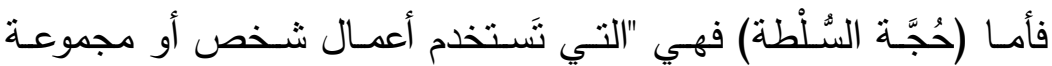

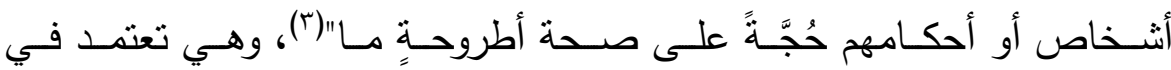

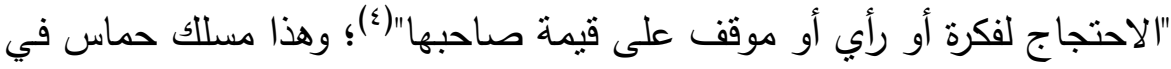

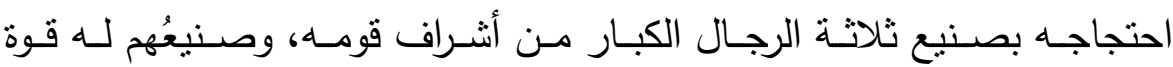
احتجاجية يسنطيع أن يحتَّ بها من بريد الاحتجاج، فهم نموذجِ يُحتذى به، وقدوةٌ

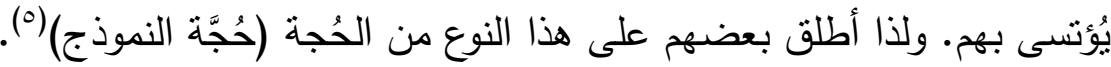

( (1) تاريخ نظريات الحجاج، لبروتون وجوتييه صو ب.

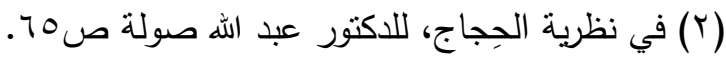

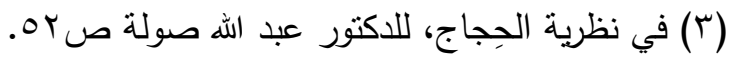

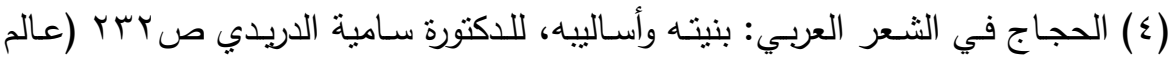

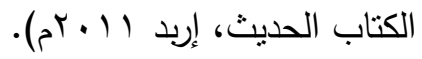

(0) انظر : تاريخ نظريات الحجاج، لبروتون وجوتييه صـ آن. 
وأما (حُجَّة التأطير) كما بُسمّيها بعض الباحثين (')، فهي التي تتجه إلى جزءِ ما فتعظِّهه وتكبّره بُغيـة التأثير العاطفي في نفوس المخاطبين. وإننا نتوخَّى في عرض هذا النوع من الحُجَّة "كثرة الإشـارات إلى الدقائق والرقائق المتعلِّقة بذلك الموضوع، تكثيفًا لحالة الحضور التي نريد أن بيتَّم بها موضوعُنا في ذهن السامعين، ولإحداث الانفعال أيضًا؛ إذ بقدر ما بكون الموضوع مخصوصًا يكون أبعتَ على الانفعال، ونصل إلى هذه الخصوصية بواسطة ذكر الدقائق والرقائق تلاك.... إنَّ مما بساعد على الإشعار بمدى حضور الحدَث ذكر مكان ذللك الحَدَث

وزمانه، مع ميلٍ إلى استخدام اللفظ الحِيّي المجسَّد دون اللفظ المجرَّد"(؟). إنَّ هذا ما نشهده عند حماس وهو يصف نلإك الوقعة، فيعتمد التشبيه(r)، ويختار أن ينقل لنا صورة الصوت لا لفظَه، لكي نعيش في أحداث تلك اللحظة الصعبة كما أرادها أن تكون، فهو يصفُ أصوات المقاتلين الذين هرب منهم -

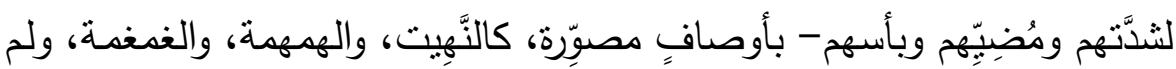
يقل: "لهم صوتُ شديدٌ أو مرعب"؛ إلى ما في الثَعر من صورٍ تهويليَّة أخرى لقطع السواعد والجماجم، ومـا وراء ذلك ممـا يمكن تخيُّله قياستًا على مـا اختار الثاعر ذكره.

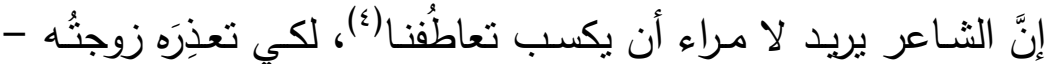

ونعذِره نحن - فيما صنع من نلاك الفَرَّة.

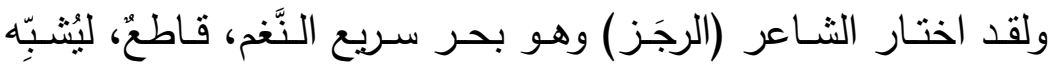
صورةَ السُّرعة في قطع الجماجم والسَّواعد، ولئلا يكون ثمـة مجال في البحر

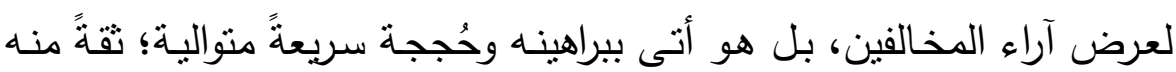

$$
\begin{aligned}
& \text { (1) انظر : الحجاج في التواصل، تأليف فيليب بروطون ص الج. } \\
& \text { (Y) في نظرية الحِجاج، للدكتور عبد الله صولة صهب- (r) }
\end{aligned}
$$

(r) انظر في الأثر الحجاجي للنتبيه والاستعارة: الحجـاج في الثـعر العربي، للدكتورة

$$
\text { سامية الدريدي صبرهr. }
$$

(ع) انظر في استدرار العطف: المغالطات المنطقية، لعادل مصطفى صبه 9. 
في نجاح أثزهـا في قلـوب المخـاطبين. وحتى القافيـة المنتهيـة بهاء السكت الصامتة الساكنة، تفي بما أراد الثاعر أن بيلِّغه من رسالة.

-

الثفرارُ يوهر حُنين:

\section{1- قَرَّةُ قُارب بن الأسود وقومِه يوهر حُنين:}

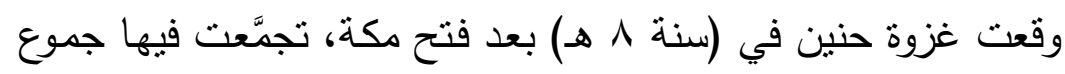

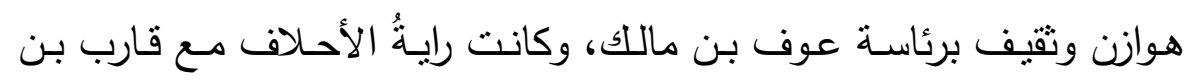
الأسود، فلما نصر الله نبيَّه وانهزم هؤلاء أسند قاربٌ رايتَه إلى شجرة وهرب هو هوبه

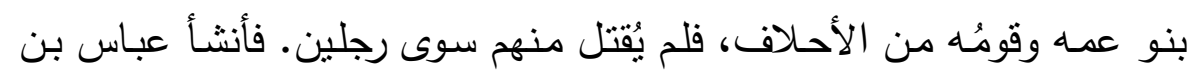

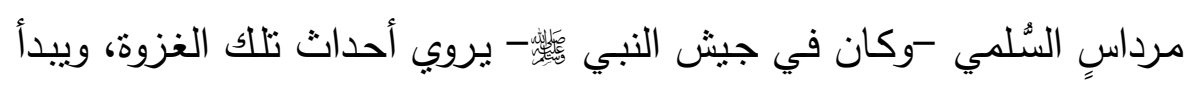

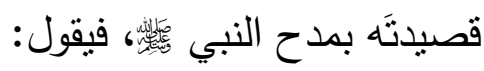

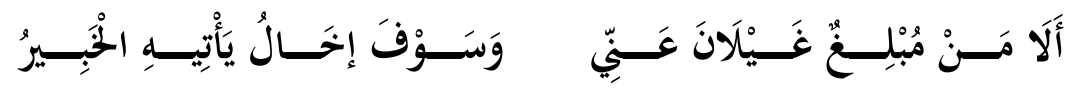

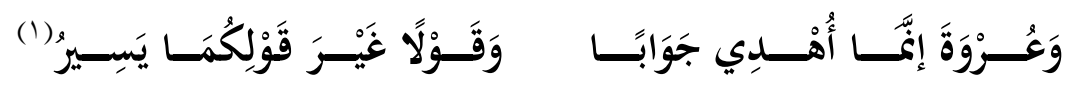

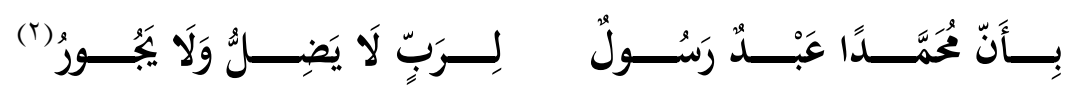
ثم يهجو قاربَ بن الأسود ويذكرُ فرارَه من بني أبيه، ونجاءه بنفسـ ومَن معه، فيقول من أبيات القصيدة:

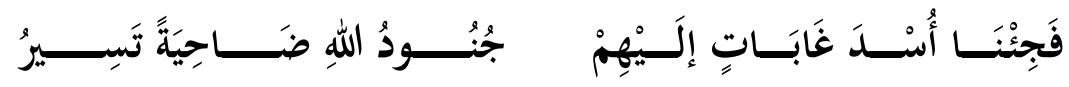

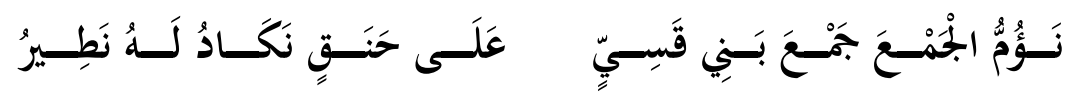

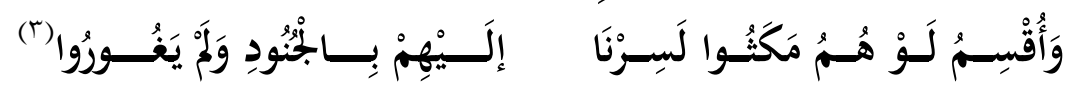

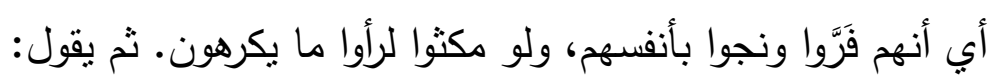

(1) غيلان: هو غيلان بن سلمة الثقي، وعروة: هو ابن مسعود الثقفي (انظر : السيرة

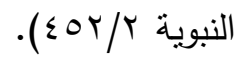

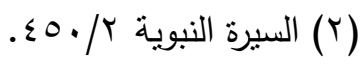

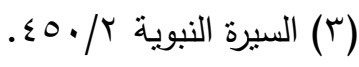




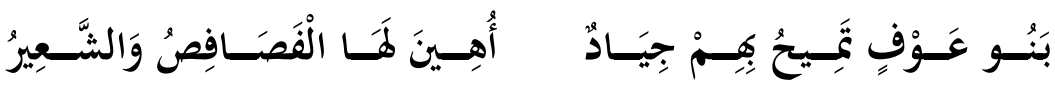

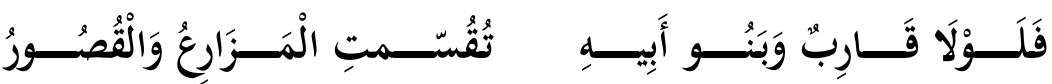

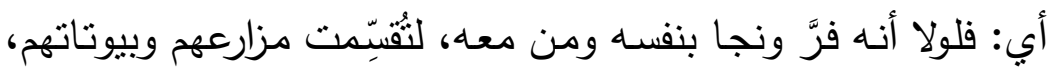

ولكنه نجا. ثم يُتبع ذلك بقوله:

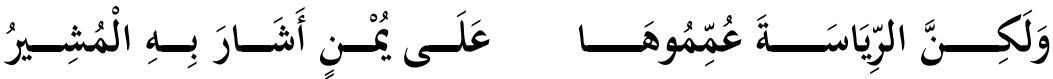

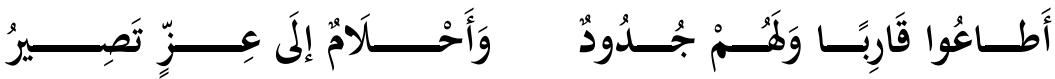

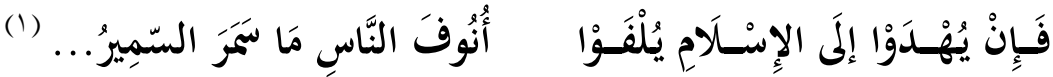

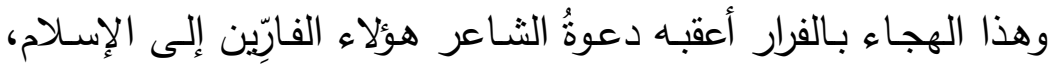

وهذه هي الغايةُ من القتال عند المسلمين، كأنه يقول لهم: إن كنتم قد أنجاكم الله بالفرار - -على ما فيه من العار - فانجوا بأنفسكم حقًا وأسلموا.

ولم يبلغنا ردّ على هذا الثّر .

\section{(-)}

9- فرَّة مالك بن عَوْفِ في حنين، وردُه، وتحليلُ حِجَاجه:

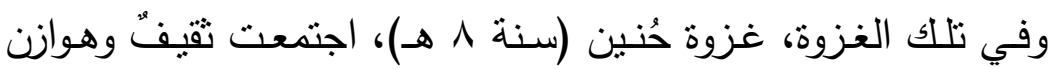
على حرب رسول الله

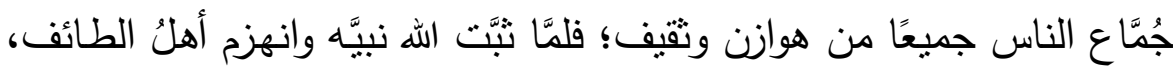
فرَّ ماللك بن عوفٍ من تلك المعركة، وأخزى قومـه، فقال قصبدةً ميميَّةً بعد

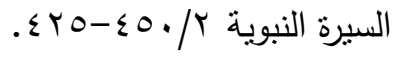

(Y) هو مالك بن عوف من بني نصر بن معاويـة، من هوازن، كان رئيس هوازن وهم يحاربون مع تَفيفٍ رسولَ الله

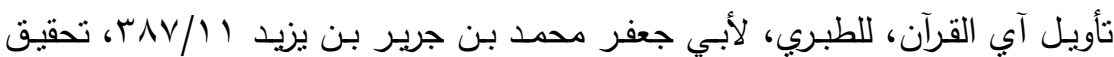

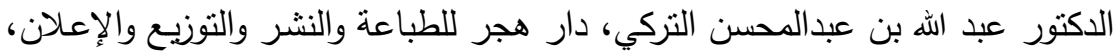

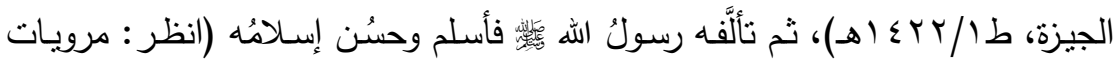

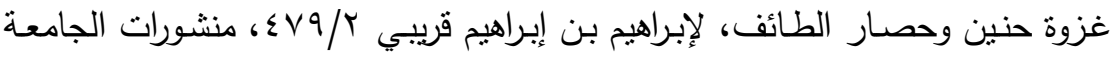

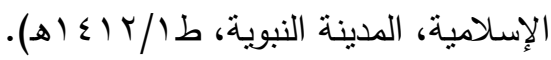


ذلك يعتذر فيها من فراره ذلك اليوم، وهو يبدؤها بهذا الغزل المقتضب المقرون بالفخر :

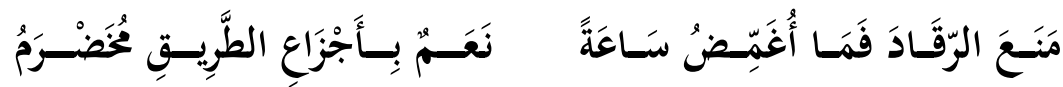

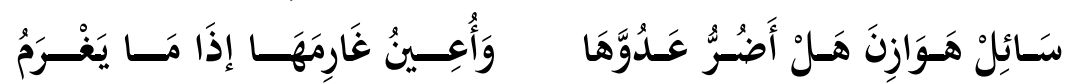

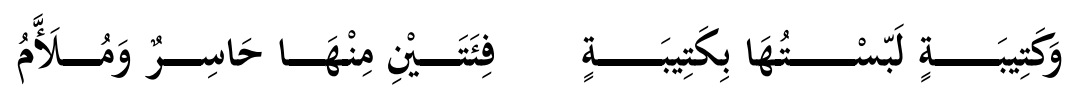

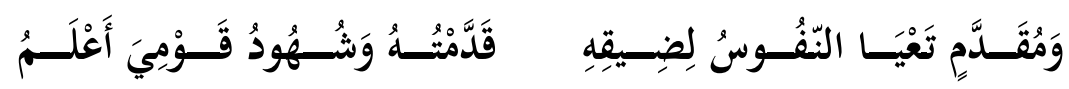

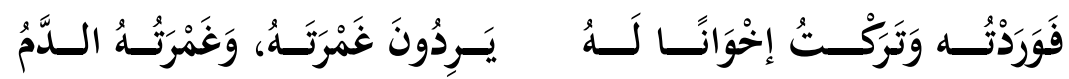

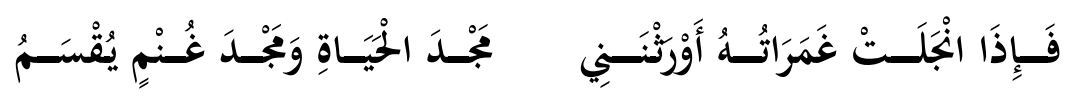
ثم يذكرُ ما رماه به قوه من فراره يوم حُنين من جيش النبيّ محمدٍ

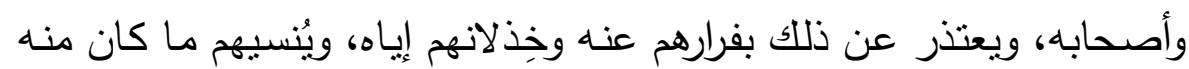
ذلك اليوم بإلقاء اللوم عليهم، من أنه يبني وهم يهدمون، يبني لهم مجدهم وهم

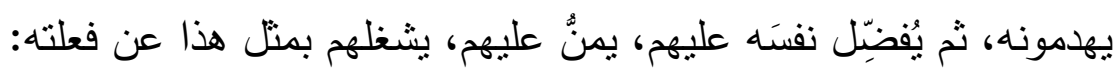

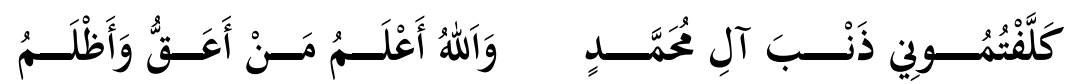

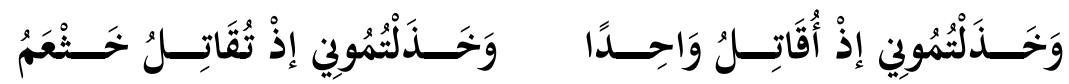

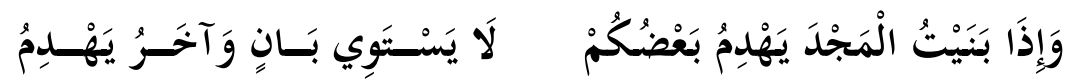
والحقيقة أنه كان سببًا من أسباب هدم ذلك المجد لقبيلته حين فر من المعركة فألبسهم العار ، وهذا النوع من الدفاع يُسميه علماءُ النفس: (الإسقاط

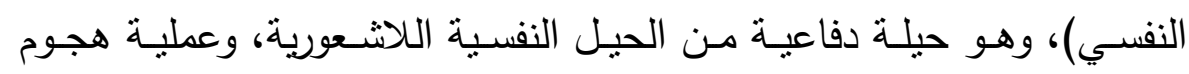
يحمي الفرد بها نفسه بإلصاق عيوبه ونقائصسه ورغباته المحرَّمة أو المستهجنة ونه

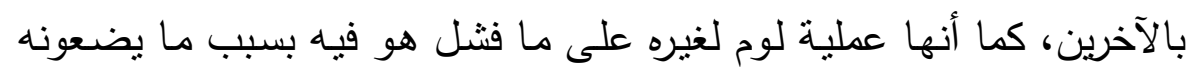

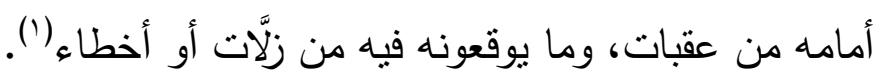

Sigmund Freud, Case Histories II (PFL 9) p. انظر : (1) 
ثم إنه يتمادى فيذكر صنائحَه ويفخر بنفسـه، وكأنَّ لسان حاله يقول: إنـه تخرق زلتي في غمـار أمجادي، ولا ينبغـي أن تُذْكَر ، فهو يبدأ قصبيدَّه بفخر ، ويُنهيها بفخر، يقول بعد الأبيات السابقة متفخرًا بنفسه:

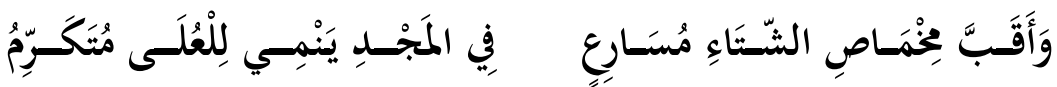

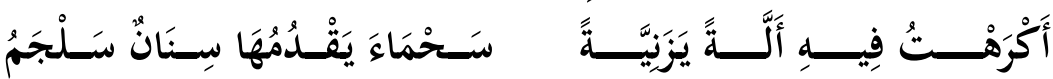

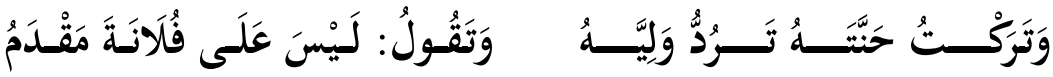

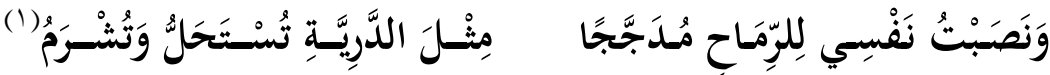

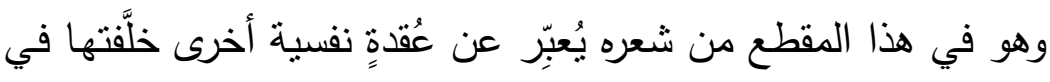
نفسه فَرَّتُه تللك، هي عُقدة العظمة في مقابل إزراء قومه عليه؛ فيدافع عن نفسه بحيلة دفاعية يسمِيِها علماءُ النفس: (التكوين العكسي)، وهي حيلة نفسية يتخذ فيها الفرد أسلوبًا بعبر عن عكس الدافع الموجود عنده، وتكون غالبًا ردة الفعل مبالغًا فيها، فـالتكوين العكسي يعمل على قمـع الدافع المثير للقلق والثـعور بالذنب، وبذلك يستريح صاحبه مؤفتًا من القلق والتوتز المرتبط بـه. ومن أمتلة التكوين العكسي: الزهو والتكبُر الناتج عن الثُعور بالنقص، وكالذي يخاف ولا

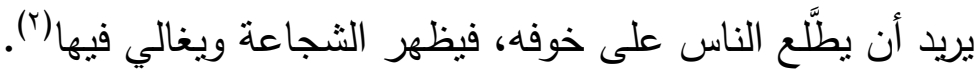

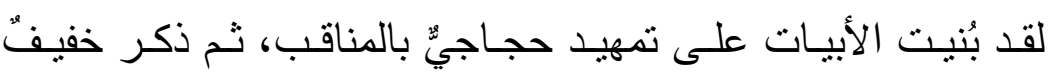

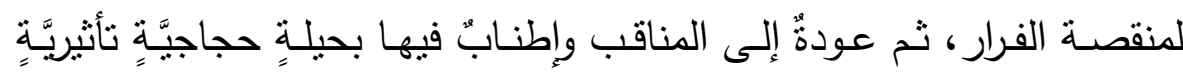
عساها تطمسُ أو تُسينا ما كان منه من مَعَرَّة الفرار .

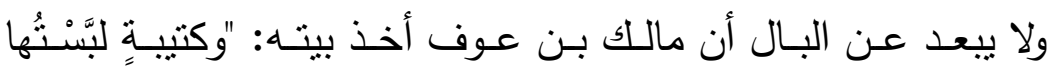
بكتيبةٍِ..."، من قول الفرَّار السُّلَميّ:

حتَّى إذا الْتَبَسَتْتُ نَفَضْتُ بِعَا يَدِي

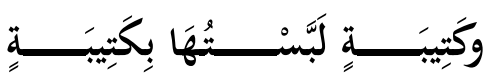

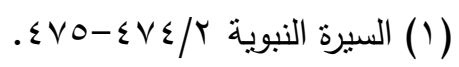

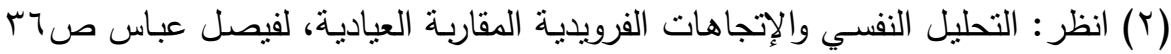

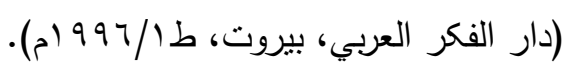


والفرَّار شـاعرٌ مخضـرم، لا ندري متى قال هذه الأبيات، ولا في أي

مناسبة قيلتْ، ولكنها من أشهر الأبيات المُنْنَدَة في هذا الباب.

\section{$\{\hat{-10}$}

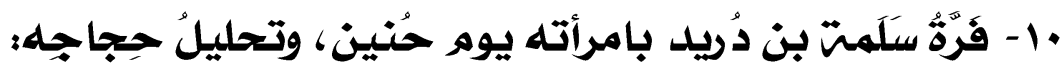

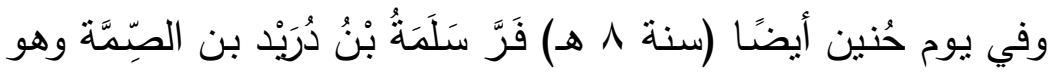

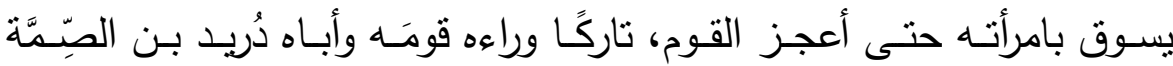
الشاعر ، الذي قُنل في نللك المعركة، فقال بعتذر عمَّا كان منه:

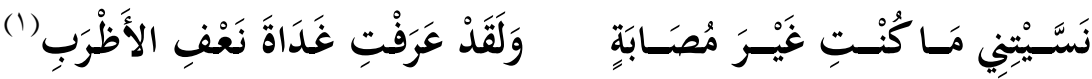

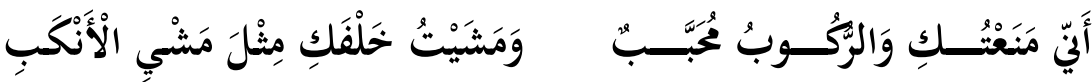

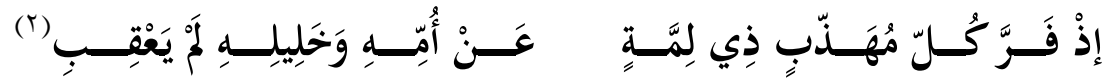

إنه يمنُّ عليها ليُنسيَها -أو لينسى هو - شؤم ما صنع، وهي حيلة التتسية. وفي الثـعر خطابُ إقناعِ بـ(حُجَّة السُّلطة) كما مرَّ معنا؛ إذ فَرَّ هؤلاء من

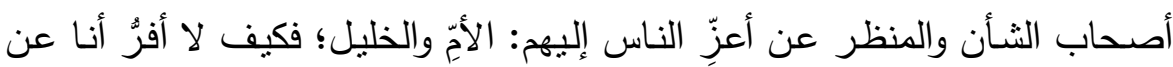
قومي وأبي؟! وقد جاء بلفظ "الأمّ"، في مقابل فراره عن "أبيه" عمدًا، كأنه يدفع عن نفسه مغبَّةَ تلك التُّهمة، فاللفظة لم تأتِ عَبًَا في شعره.

\section{-}

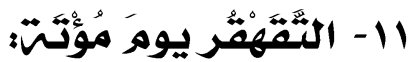

وقعت غزوة مؤتة (سنة ^ هـ)، وكانت تسمى غزوة الأمراء؛ لأنه قُتل فيه

أمراء الجيث الثلاثة رضي اله عنهم: زيد بن حارثة، وجعفر بن أبي طالب، وعبد

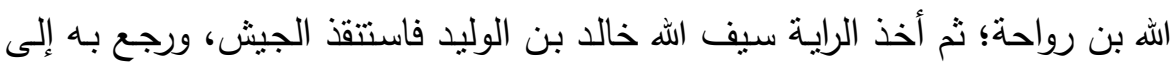

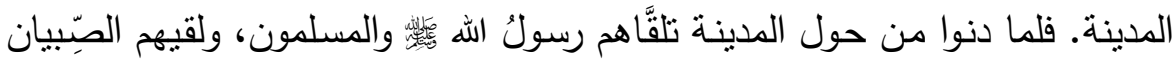

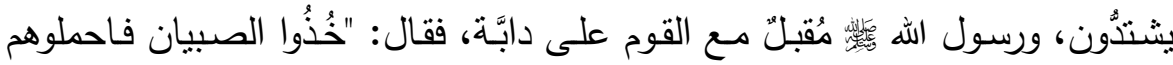

(1) نعف الأظرب: كذا في الأصل بالظاء المعجمة، وفي معجم ياقوت: الأطرب: بالطاء

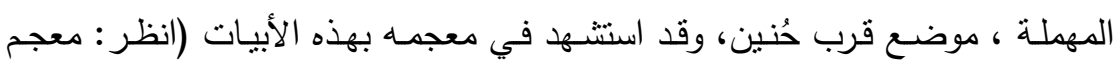

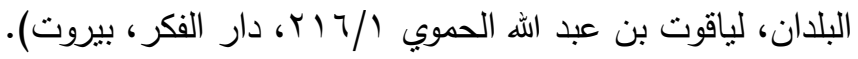

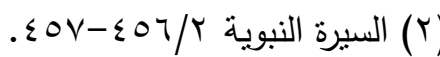


وأعطوني ابن جعفر"، فأُتي بعبد الله فأخذه فحمله بين يديه، وجعل الناس يحثُّون

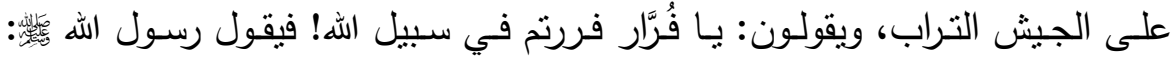

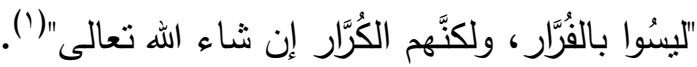
لقد ضاقت البسيطة على أصحاب مؤنة، وأظلمت الدنيا في أعينهم؛ للذي حدث ذلك اليوم؛ فقي (السيرة النبوية) عن بعض آل الحارث بن هشام، عن أم سلمة زوج النبي

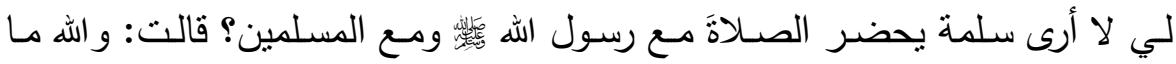

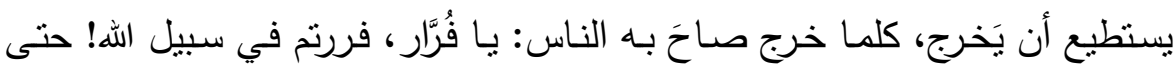

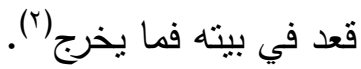

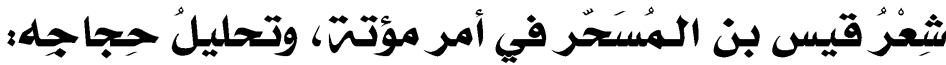

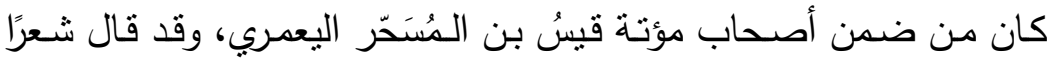

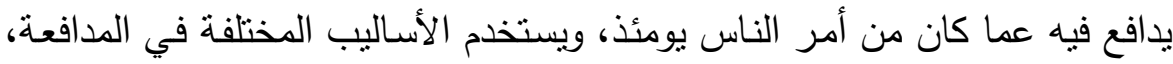

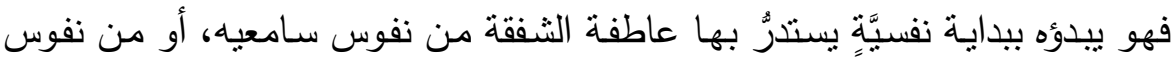

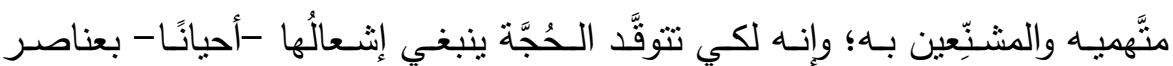

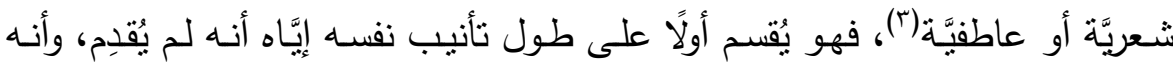

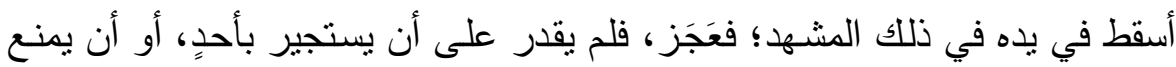

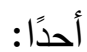

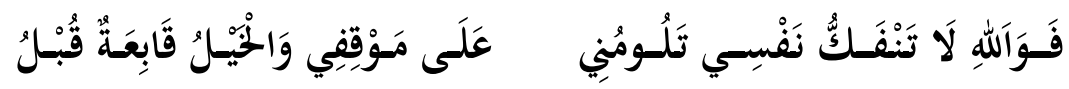

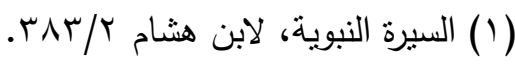

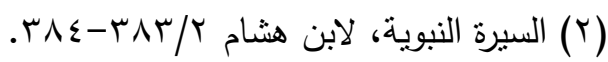

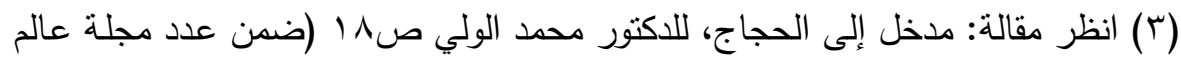

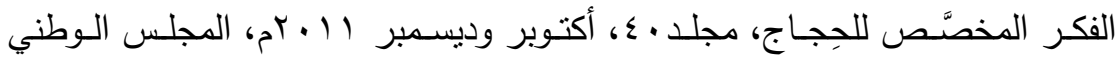

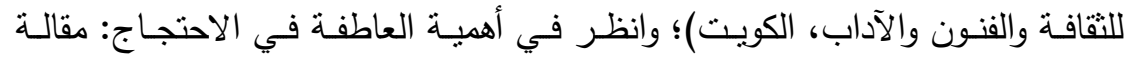

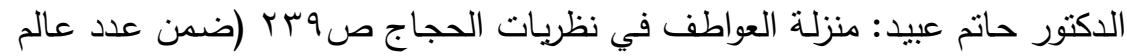

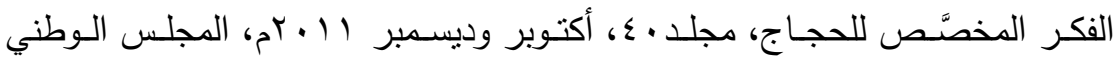
للتقافة والفنون والآداب، الكويت). 


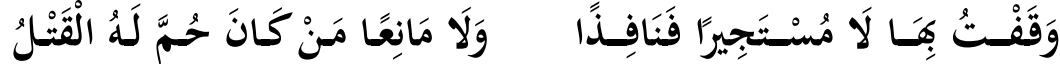

ثم لا يلبث بعد ذللك أن يعود إلى عقله فيحتجُج بـ(حُجة السُّلطة)، إذ يحتجُّ

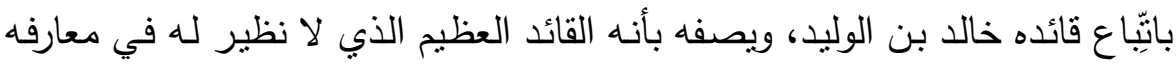

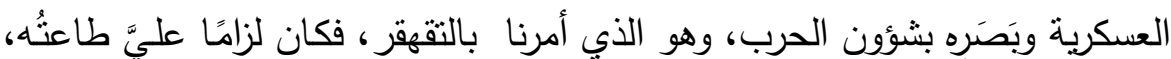

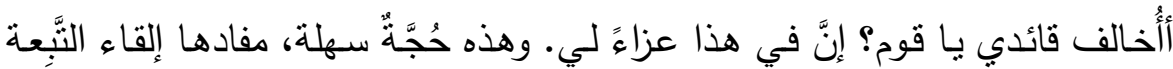

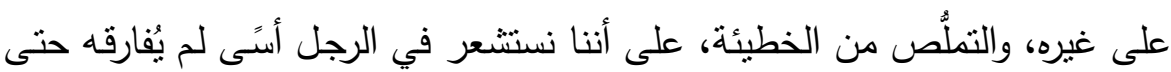
وهو يُحاجج عن نفسه، إذ يقول:

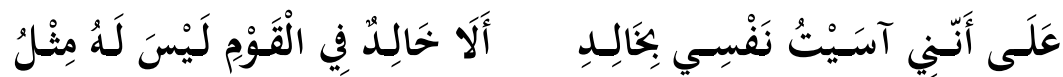

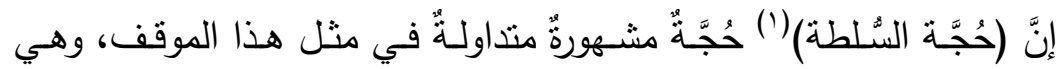

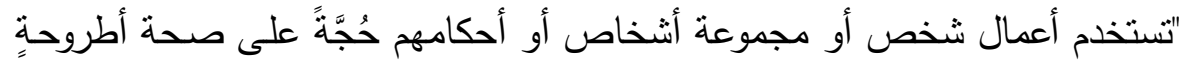

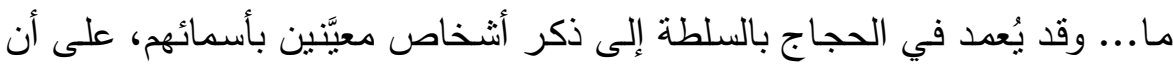
تكون سلطة هؤلاء جميعًا معترفًا بها من قبل جمهور السامعين، في المجال الذي لفي

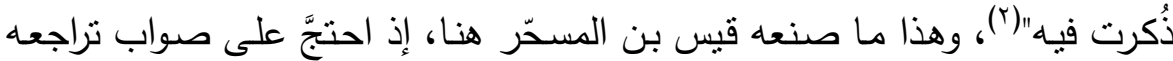

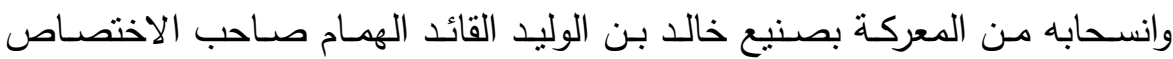

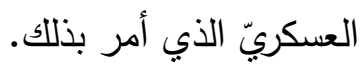
والثاعر قد عمد هنا أيضًا إلى الثاء على خالإٍ بأنه "ليس لله مثلُ" أي في

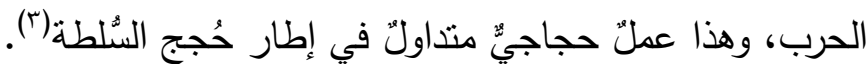

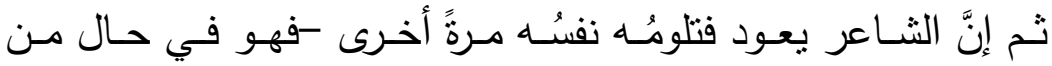
التجاذب بين ملامـة نفسه إيَّاه، واعتذاره هو عنها - كيف يترك جعفرًا صريعًا

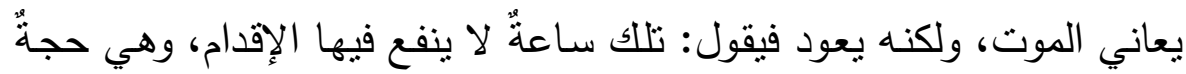
مشهورة متداولة: أنه حين لا ينفع الإقدام، فالإحجامُ هو الرأي الصائب:

(1) انظر : الحجاج في التواصل، تأليف فيليب بروطون ص الجا.

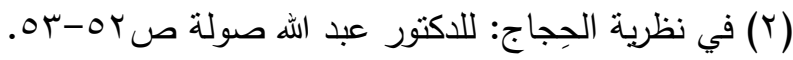

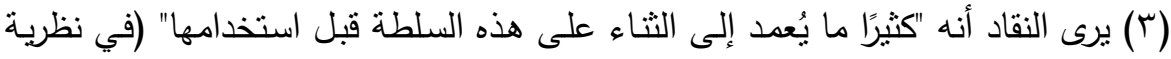

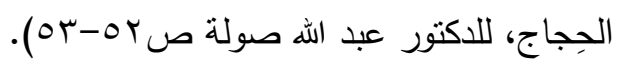




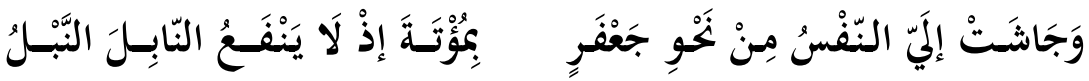

بـل قد سـاعدهم على هذا التحيُّزُ المهاجرون هوهـم مـن هم فضـلًا

وتقدُّمًا وإسلامًا - فحاجزوا بينهم وبين العدوِ حتى انسحبوا:

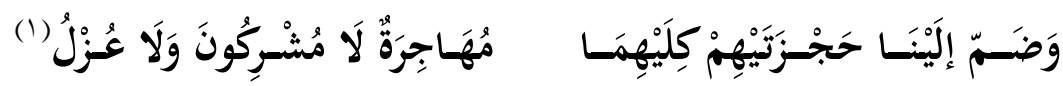

وهذا احتجـاجُ بصـلاح القوم؛ إذ كيف تلومونتـا، وقد تحيَّز بنـا خالد، وهو

أحسنُنا حربًا، وقد حاجز عنا المهاجرون، وهم أقوانا دينًا وإيمانًا؛ لم نُخطئ حينئذ.

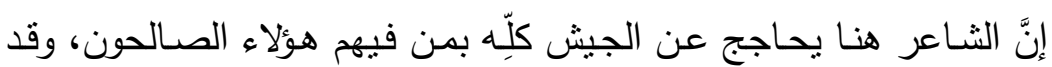
ذهب أرسطو إلى أنَّ العوامل التي تدعو إلى بعث الثقة في الخطيب بحُجَّته ثلاثنة،

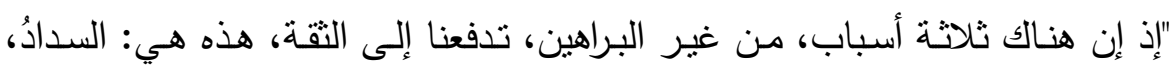

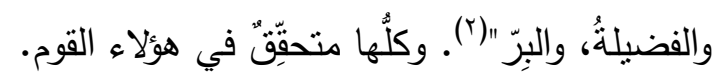

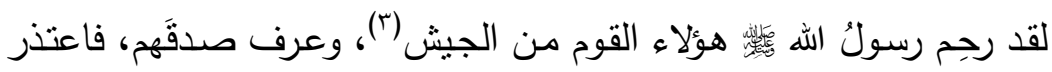

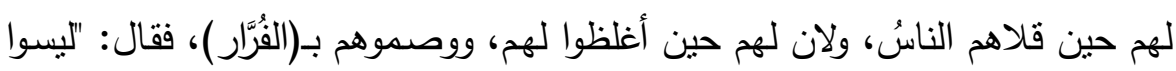

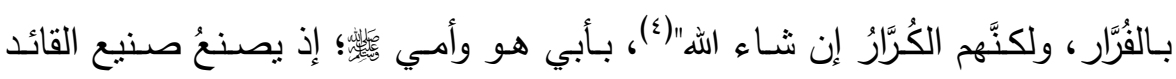

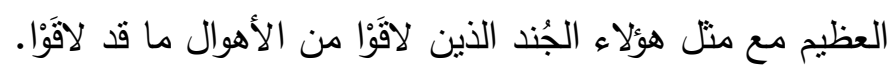

\section{-}

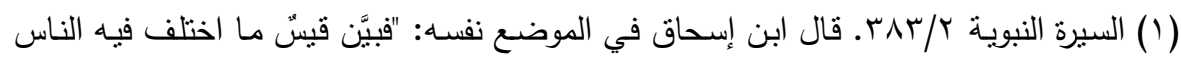
من ذلك في شعره، أن القوم حاجزوا وكرهوا الموت، وحقَّق انحياز خالد بمن معه".

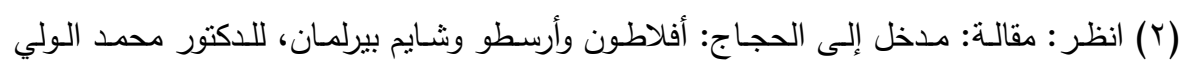

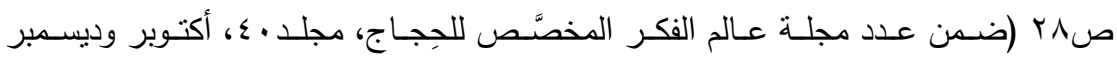

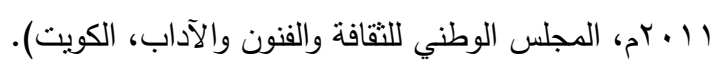

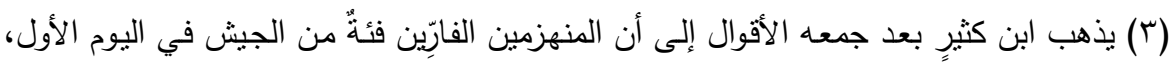

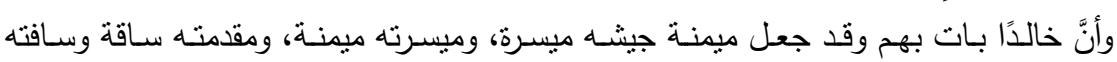

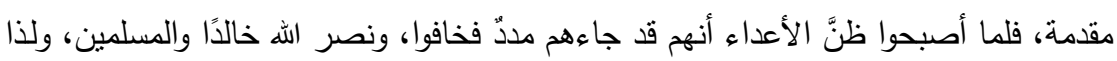

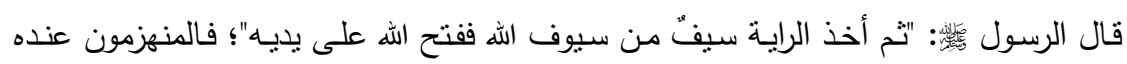

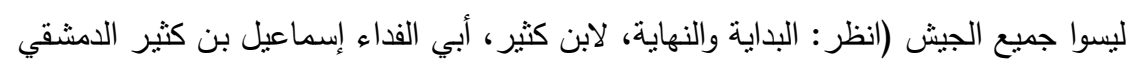

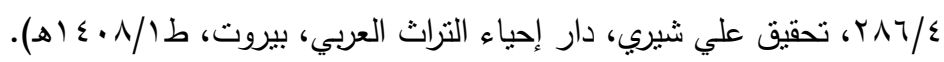


رصد هذا البحث ظـاهرةً مهمة من ظواهر الثِِّعر في العهد النبوي،

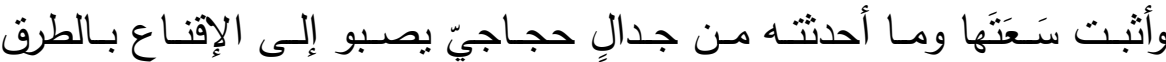

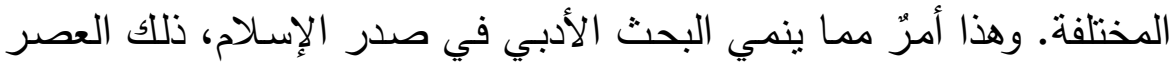
المتّهم دائمًا بضعف شعره وقلّتهه، فهذا ديوانٌ كامل في موضوع فريدٍ مختلف. لقد وقف البحث على إحدى عشرة واقعةً من وقائع الفرار في العهد النبوي، أي في نحو عشر سنين فحسب، ولّدت هذه الوقعات شعرًا كثيرًا من ون شـعر الفرار • إن البحث في شـعر تلك الحقبة يستلزم تغييرًا للمفاهيم السـابقة

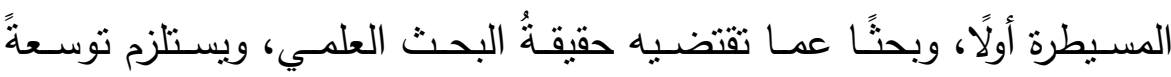

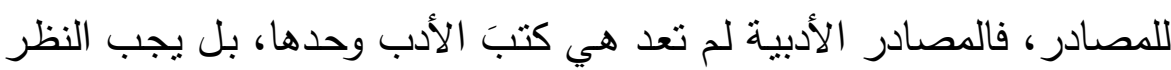

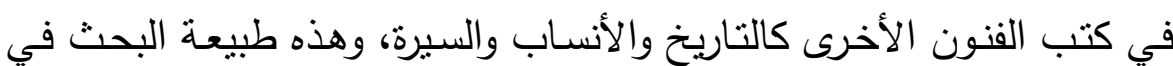
أدب الحضارة العربية الإسلامية. إن مما يدل على قيمة ظاهرة الفرار كثرة الشعراء المشاركين فيها بين الهين مهاجم متّهم، ومدافعٍ عن نفسه، وكثرة الخائضين في أمرها من غير الشعراء،

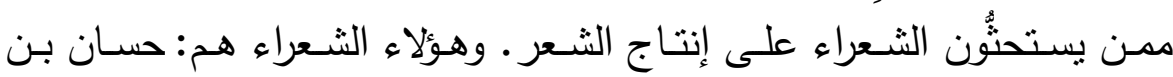
تابت، والحارث بن هشَام، أبو سفيان بن حرب، وهُبَيْرة بن وَهْبِ، وابن لُقَيٍَِ

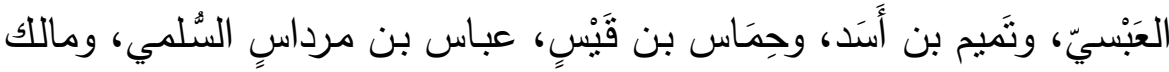

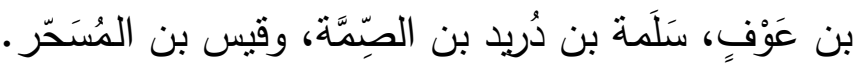

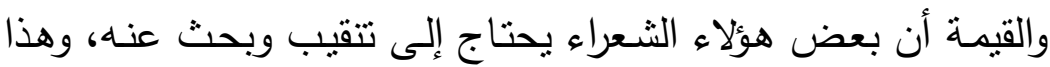
مما يدعو إليه البحث، ولعل الله يوفّق إلى ذلك بحوله وقوته.

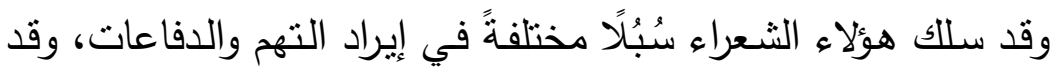

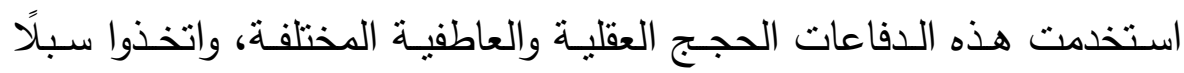
مختلفة للتأثير في المخاطبين نفسيَّا ومنطقيَّا، أو مغالطيَّا في بعض الأحيان، بما بيّناه في غضون البحث، وبما لا يحسن ذكره هنا لئلا تختلط المصطلحات 


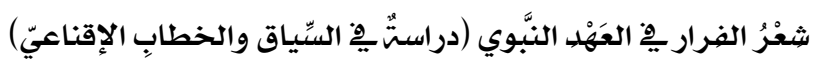

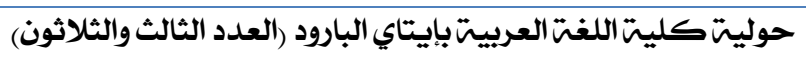

والمفاهيم؛ لوجود كثيرٍ من هذه الحجـج في العلوم النظريـة المختلفة بأسماء مختلفة.

وهذا جدولٌ يوققنا على تصور بعضٍ من حقائق هذا البحث:

\begin{tabular}{|c|c|c|c|c|}
\hline الشاعر المدافع & الشاعر المهاجِم & السَّنة & 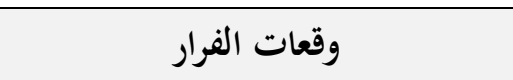 & \\
\hline- & حسان بن ثابت & D T & فرار المشركين يوم بدر & 1 \\
\hline الحارث بن هشام & حسان بن ثابت & or & فرة الحارث بن هشام يوم بدر & r \\
\hline الحارث بن هشام & أبو سفيان بن حرب & D & فرة الحارث بن هشام يوم بدر & $=$ \\
\hline هُبَبَرة بن وَهْدِ & - & هo & فِرَار المشركين يوم المحنْدق & $r$ \\
\hline- & حسان بن ثابت & so & فَرَّةُ عِكِرْمة بن أبي جهلٍ يوم الخَنْدق & $\varepsilon$ \\
\hline- & ابن لُقُيِمٍ العَبْسيّ & $\Delta V$ & فِرارُ يهود خَيْبر & 。 \\
\hline تَتَمم بن أَسَد & - & $ه$ & فَرَّةُ تَمَيم بن أَسَد قُبيْل الفتح & 7 \\
\hline رحمَاس بن قَيْسِ & - & $ه$ & فِرار حِمَاس بن قَيْسِ والقُرشيين يوم الفتح & v \\
\hline- & 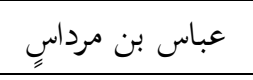 & $ه$ & فَرَّةُ قارب بن الأسود وقومِه يوم حُنين & $\wedge$ \\
\hline مالك بن عَوْفٍ & - & $ه \wedge$ & فَرَّة مالك بن عَوْفٍ في حنين & 9 \\
\hline سَلَمة بن دُريد & - & $ه$ & فَرَّةُهُ سَلَمة بن دُريد بامرأته يوم حُنين & 1. \\
\hline قيس بن المُسَحَر & - & $ه$ & 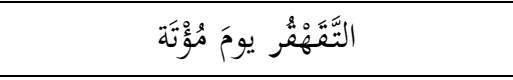 & 11 \\
\hline
\end{tabular}

إنَّ شعر الفرار في العصر النبوي قد فتح لنا أبوابًا أخرى نطلَّع بها

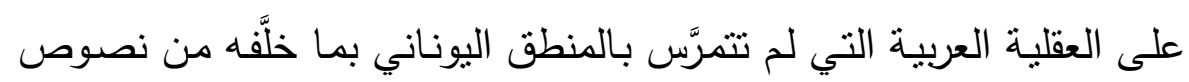

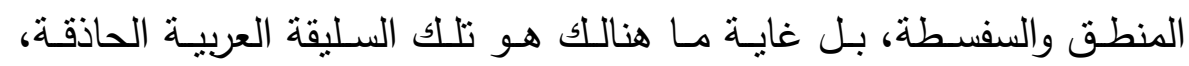
والعقليَّة الفطريَّة الحادَّة التي تعكس لنا صورةً لا بأس بها عن التكوين الفكريّ والنفسيّ لطائفةٍ صالحةٍ من شعراء ذلك العصر .

- 


\section{المصادر والمراجع:}

1. الأدب في عصر النبوة والراشدين، للدكتور صـلاح الدين الهادي (مكتبة

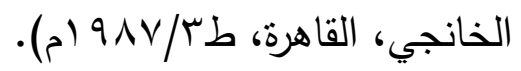

r. الاستبعاب في معرفة الأصحاب، لابن عبد البر، أبي عمر يوسف بن عبد الله بـن محمـد النــري القرطبـي (تحقيـق علي محمــ البجـاوي، دار

$$
\text { الجيل، بيروت، ط الب/ ب9 } 9 \text { (م). }
$$

r. أسد الغابة، لابن الأثثر، أبي الحسن عز الدين علي بلن أبي الكرم محمد الجزري، عز الدين ابن الأثير (دار الفكر، بيروت 9 .ـ (هـ).

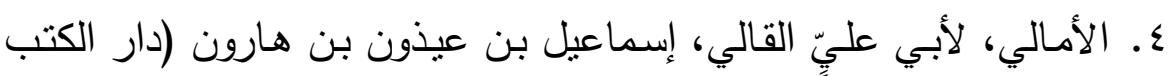

$$
\text { المصرية، طب/T ب } 9 \text { (م). }
$$

ه. البداية والنهاية، لابن كثثر، أبي الفداء إسماعيل بن كثثر الدمشقي (تحقيق

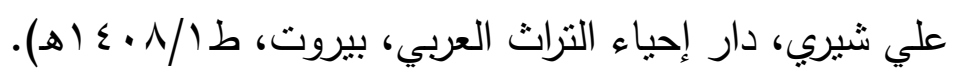

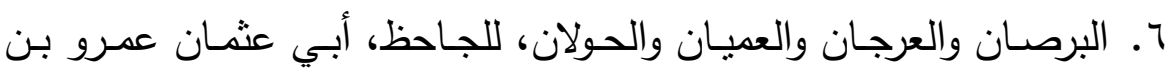

$$
\text { بحر (تحقيق عبد السلام هارون، دار الجيل، بيروت، ط / / ـ إ (هـ). }
$$

V. تاريخ الرسل والملوك، لأبي جعفر محمد بن جرير بن يزيد الآملي (دار

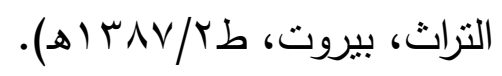

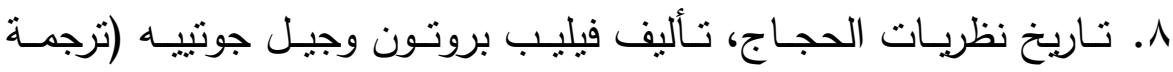
الدكتور محمد صالح ناحي الغامدي، مركز النشر العلمي، جامعة الملك

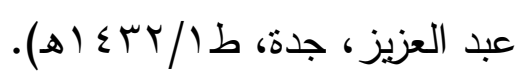

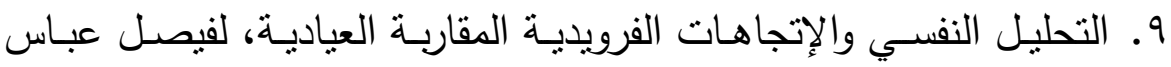

$$
\text { (دار الفكر العربي، بيروت، ط //997 (م). }
$$

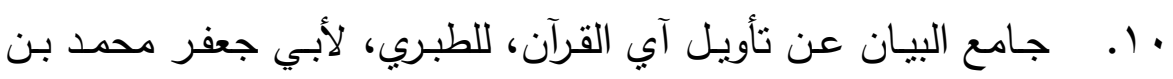
جرير بن يزيد الآملي (تحقيق الدكتور عبد الله بن عبد المحسن التركي، دار هجر للطباعة والنشر والتوزيع والإعلان، الجيزة، طا / ب ع (هـ). 
ال. الحجاج في التواصل، تأليف فيليب بروطون (ترجمة محمد مشبال

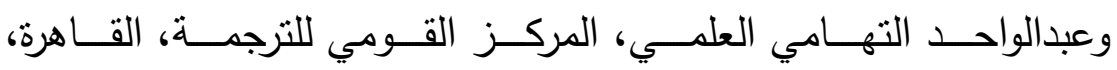

$$
\text { ط }
$$

r ا. الحجاج في الثـعر العربي: بنيته وأسـاليبه، للدكتورة سـامية الدريدي

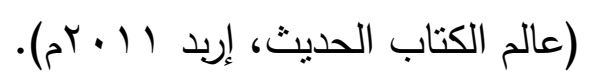

سا. خزانة الأدب ولُبُّ لُباب لسـان العرب، لعبد القادر بن عمر البغدادي

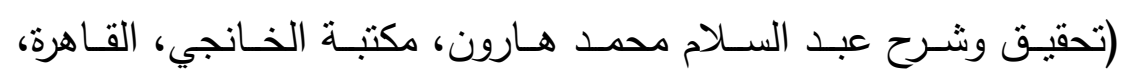

$$
\text { . (م) } 99 \mathrm{~V} / 1<2
$$

ع ا. الخطابة، بالترجمة العربية القديمة، لأرسطوطاليس (حققه وعلَّق عليه

$$
\text { عبد الرحمن بدوي، دار القلم، بيروت } 9 \text { و (م). }
$$

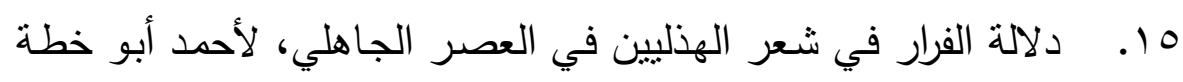

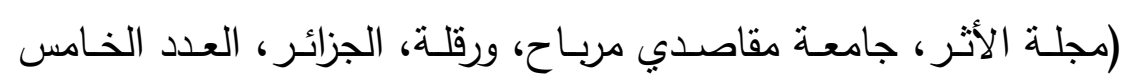

$$
\cdot(5, \cdot)
$$

7 1. ديوان المعاني، لأبي هـلال العسكري، الحسن بن عبد الله بن ســل

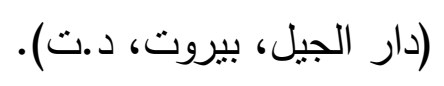

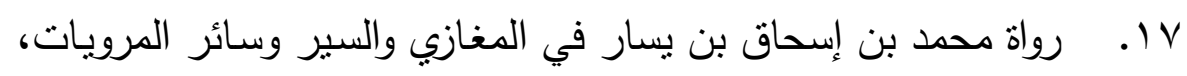

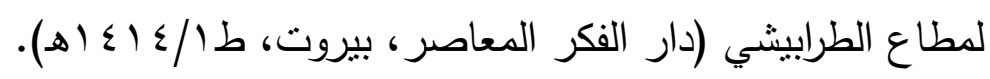

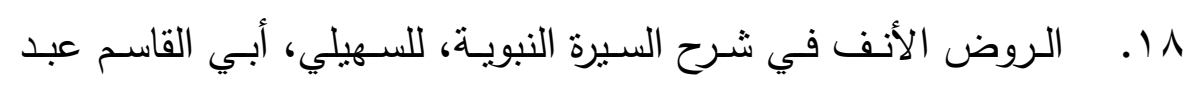
الرحمن بن عبد الله بن أحمد (تحقيق عبد الرحمن الوكيل، دار إحياء

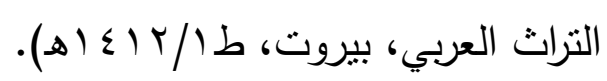

9 1. سمط النجوم العوالي في أنباء الأوائل والتوالي، للعصامي، عبد الملك بن حسين بن عبد الملك المكي (تحقيق عادل أحمد عبد الموجود وعلي

$$
\text { محمد معوض، دار الكتب العلمية، بيروت، ط /9 (1) (هـ). }
$$


• r. السيرة النبوية، لابن هشام، أبي محمد عبد الملك بن هشام بن أيوب

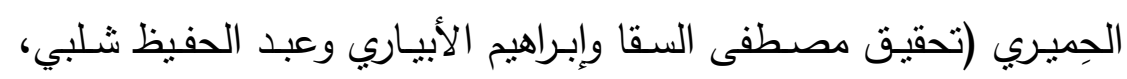

$$
\text { مكتبة مصطفى البابي الحلبي، القاهرة، طر/900/ (م). }
$$

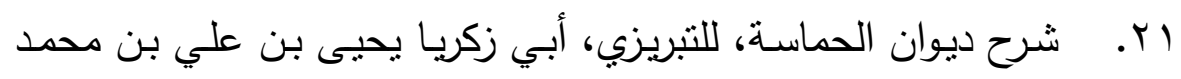

$$
\text { الثيبانيّ التبريزي (دار القلم، بيروت، دت). }
$$

r. . الشعر العربي في القرن الأول الهجري، للاكتور محمد مصطفى هدارة

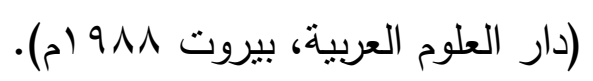

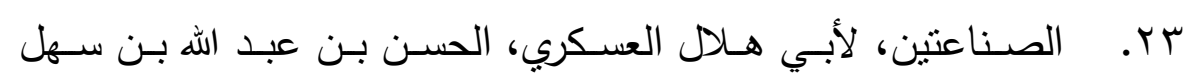
(تحقيق علي محمد البجاوي ومحمد أبو الفضل إبراهيم، المكتبة العصرية، لابهية

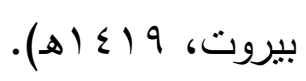

ع ז. عيون الأثر في المغازي والسبِّيَر، لابن سيد الناس، محمد بن محمد بن

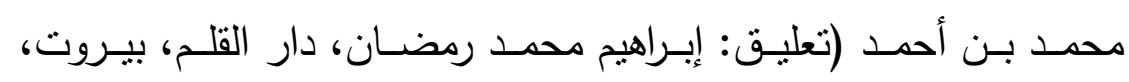

$$
\text { (ه) (ه) }
$$

OY. الفرار في الثعر الجاهلي: المواقف واختلاف وجهات النظر، لمشتاق

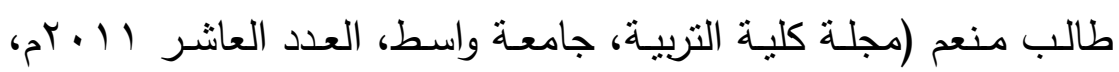

$$
\text { ص. }
$$

جr. في نظريـة الحِجـاج: دراسـات وتطبيقـات، للـدكتور عبـد الله صـولة

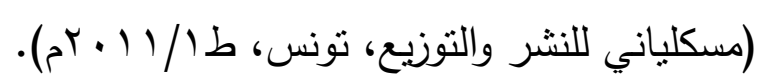

rV محمد أبو الفضل إبراهيم، دار الفكر العربي، القاهرة، طس/V إع اهـ).

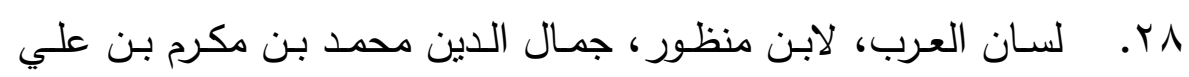
الإقريقي (تحقيق عبد الله علي الكبير وزميليه، دار المعارف، القاهرة).

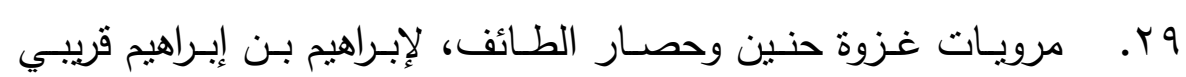

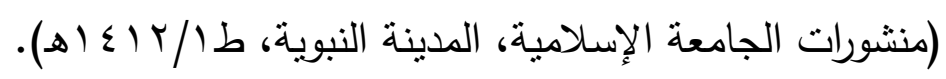


• ·. معجم البلدان، لياقوت بن عبد الله الحموي (دار الفكر، بيروت، د.

اس. معجم الثـعراء، للـمَزُْباني، أبي عبيد الله محمد بن عمران (تصحيح

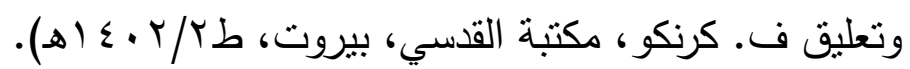

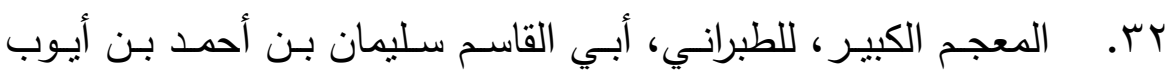

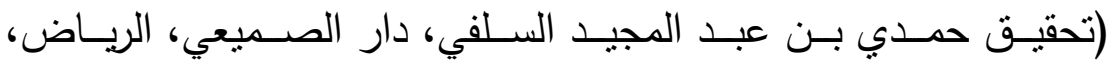

$$
\text { . (ه) }
$$

سr. المغازي، للواقدي، محمد بن عمر بن واقد (تحقيق مارسدن جونس،

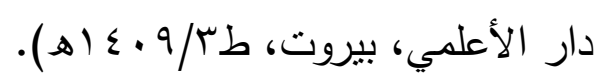

؟r. المغالطـات المنطقيـة: فصـول في المنطـق غيـر الصـوري، لعـادل مصطفى (المجلس الأعلى للتقافة، القاهرة، ط / V/ . . rم).

هr. المفضَّليات، للمفضل بن محمد بن بعلى الضبي (تحقيق وشرح: أحمد الاعلى محمد شاكر وعبد السلام محمد هارون، دار المعارف، القاهرة، ط/؟ آ). بس. مقالـة: منزلــة العواطف في نظريـات الحجـاج، للـدكتور حـاتم عبيد (ضمن عدد عالم الفكر المخصَّص للحجاج، مجلد ·ـ؛، أكتوبر وديسمبر 11 ـ بم، المجلس الوطني للنقافة والفنون والآداب، الكويت).

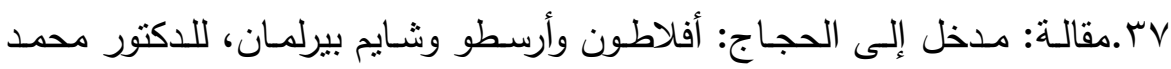

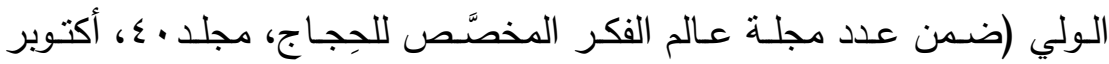
وديسمبر (1) + بم، المجلس الوطني للثقافة والفنون والآداب، الكويت). ^ז.المنطق، لمحمد رضا المظفر (دار التعارف للمطبوعات، بيروت 7 × . rم). 9 ب.موسـوعة علم النفس والتحليل النفسي، لعبد المـنعم الحفنـي (مكتبـة مدبولي،

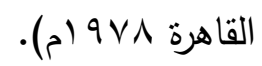

40.Sigmund Freud, Case Histories II (PFL 9).

41. The Ego and The Mechanisms of Defence, Anna Freud, Karnak books, Exeter, 1993. 